Syariful Fahmi 


\section{MEMBANGUN MULTIMEDIA INTERAKTIF}

Edisi 1

Syariful Fahmi M. Pd

2018 

Syariful Fahmi

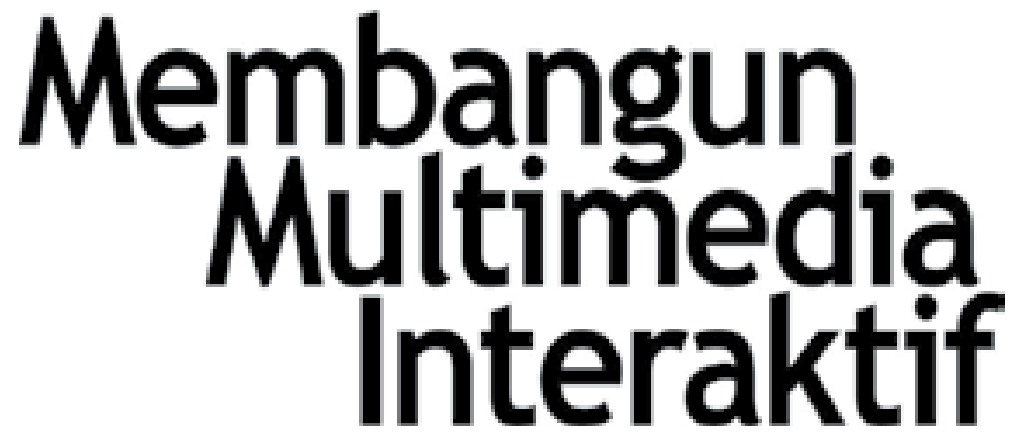


Copy right @2018, Syariful Fahmi, M. Pd

All right reserved

\section{Membangun Multimedia Interaktif, Edisi 1}

Syariful Fahmi M. Pd

Penyelaras akhir: Ahmala Arifin

Desain sampul: Ruhtata

Lay out/tata letak Isi: Hambali AI-Musa

Perpustakaan Nasional: Katalog Dalam Terbitan (KDT)

Membangun Multimedia Interaktif/Syariful Fahmi

Yogyakarta: CV. Bildung Nusantara, 2018

viii +182 halaman: $14,5 \times 21 \mathrm{~cm}$

ISBN: 978-602-50675-9-4

Cetakan Pertama: 2018

Penerbit:

Bildung (CV. Bildung Nusantara)

Jl. Raya Pleret KM 2

Banguntapan Bantul Yogyakarta 55791

Telpn: +6281227475754 (HP/WA)

Email: bildungpustakautama@gmail.com

Website: www.penerbitbildung.com

\section{Anggota IKAPI}

Hak cipta dilindungi oleh undang-undang. Dilarang mengutip atau memperbanyak sebagian atau seluruh isi buku tanpa seizin tertulis dari Penerbit. 


\section{PENGANTAR PENULIS}

Salah satu penunjang dalam proses pembelajaran adalah buku ajar bagi mahasiswa. Buku yang baik adalah buku yang menarik dipelajari, mudah dipahami, dan tidak membosankan serta memberikan makna. Salah satu mata kuliah di semester 4 Pendidikan Matematika Universitas Ahmad Dahlan yang membutuhkan buku ajar adalah Multimedia Pembelajaran.

Mata kuliah Multimedia Pembelajaran tidak hanya sekadar membahas teori tentang media, akan tetapi lebih menitikberatkan pada proses penalaran dan penyusunan multimedia yang menarik, informatif serta interaktif. Artinya, dengan belajar Multimedia Pembelajaran mahasiswa dapat berpikir kritis serta sistematis, bukan hanya berteori tentang media, melainkan juga mengembangkannya. Oleh karena itu, penulis menyusun buku ajar ini dengan dilengkapi cara-cara membangun multimedia yang interaktif.

Akhirnya, penulis mengucapkan terima kasih kepada semua yang telah banyak membantu, sehingga pembuatan buku ajar ini dapat terselesaikan. Saran dan kritik dari pembaca selalu penulis tunggu untuk perbaikan kualitas buku ajar ini.

Yogyakarta, Januari 2018 


\section{DAFTAR ISI}

Pengantar Penulis...................................................................... V

Daftar Isi...........................................................................................vii

Bab 1 Media dan Multimedia Pembelajaran .......................... 1

1. Pengertian Media Pembelajaran ..................................... 5

2. Pengertian Multimedia Interaktif..................................... 23

3. Teori-teori Belajar yang Melandasi Pengembangan

Multimedia Berbasis Komputer..................................... 31

4. Kualitas Pembelajaran..................................................... 37

5. Dampak Multimedia Pembelajaran Interaktif.............. 40

6. Peningkatan Kualitas Pembelajaran dengan

Multimedia............................................................................... 43

Bab 2 Mengenal E-Learning dengan Moodle ......................... 47

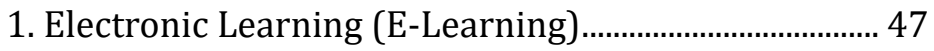

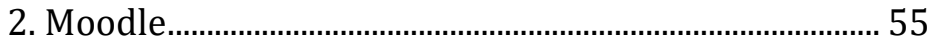

Bab 3 Merancang CD Interaktif Media Pembelajaran ....... 73

1. Perencanaan ........................................................................... 73

2. Penyusunan Konsep Media ............................................ 74

3. Rancangan Konsep dalam Bentuk Dokumen

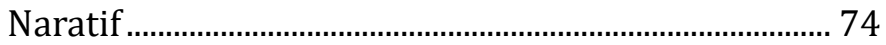

4. Penyusunan Desain atau Rancangan ............................. 76

5. Pembuatan Diagram Alir (Flow Chart) ........................ 77

6. Manajemen Directory ........................................................ 79

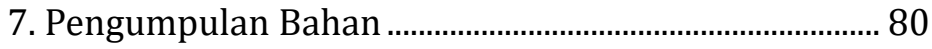

Bab 4 Desain Pengembangan Multimedia Interaktif ........ 81

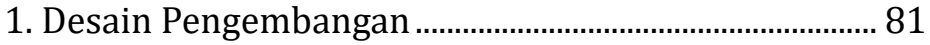




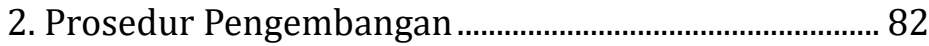

3. Uji Coba Produk................................................................... 84

4. Instrumen Pengembangan ............................................... 85

5. Teknik Analisis Data .......................................................... 87

Bab 5 Mengenal Macromedia Flash Professional 8 ........... 91

1. Dasar-dasar Macromedia Flash Professional 8 ........... 92

2. Teknik-teknik Pembuatan Animasi Dasar

Menggunakan Macromedia Flash 8 .............................. 99

Bab 6 Membuat Tombol (Button) ..............................................111

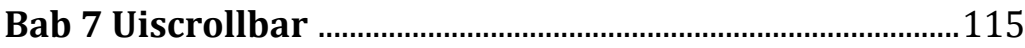

Bab 8 Membuat Password …....................................................117

Bab 9 Memasukkan Suara .......................................................121

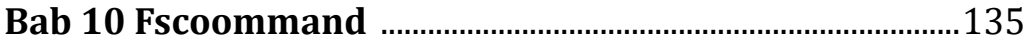

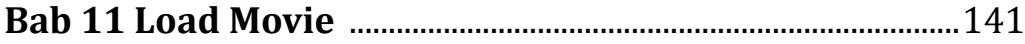

Bab 12 Membuat Kalender ..................................................145

Bab 13 Membuat Soal Pilihan Ganda .....................................149

Bab 14 Memasukan Video ke Dalam Flash .........................169

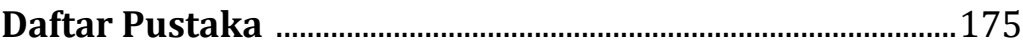

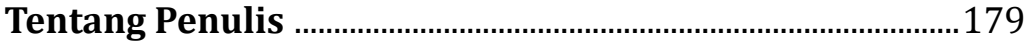




\section{MEDIA DAN \\ MULTIMEDIA \\ PEMBELAJARAN}

Dalam bab ini diuraikan mengenai:

[1] Pengertian Media Pembelajaran

[2] Pengertian Multimedia Interaktif

[3] Teori-teori yang Melandasi Pengembangan

Multimedia Berbasis Komputer

[4] Kualitas Pembelajaran

[5] Dampak Multimedia Pembelajaran Interaktif

[6] Peningkatan Kualitas Pembelajaran dengan Multimedia

Pendidikan adalah usaha sadar dan sistematis, yang dilakukan oleh orang-orang yang diserahi tanggung jawab untuk memengaruhi peserta didik sehingga mempunyai sifat dan tabiat sesuai dengan cita-cita pendidikan (Achmad Munib,2004:34). Pendidikan ialah pimpinan yang dierikan dengan sengaja oleh orang dewasa kepada anak-anak, dalam pertumbuhannya (baik jasmani maupun rohani) agar berguna bagi diri sendiri dan masyarakat (M.Ngalim Purwanto, 2002:10). Dalam arti lain, pendidikan merupakan pendewasaan peserta didik agar dapat mengembangkan bakat, potensi, dan keterampilan yang dimiliki dalam 


\section{MEMBANGUN MULTIMEDIA INTERAKTIF}

menjalani kehidupan. Oleh karena itu, sudah seharusnya pendidikan di desain guna memberikan pemahaman dan meningkatkan prestasi belajar peserta didik (siswa).

Prestasi belajar siswa disekolah sering diindikasikan dengan permasalahan belajar dari siswa tersebut dalam memahami materi. Indikasi ini dimungkinkan karena faktor belajar siswa yang kurang efektif, bahkan siswa sendiri tidak merasa termotivasi didalam mengikuti pembelajaran dikelas. Akibatnya, siswa kurang atau bahkan tidak memahami materi yang bersifat sukar, yang diberikan oleh guru tersebut.

Kecenderungan pembelajaran yang kurang menarik ini merupakan hal yang wajar dialami oleh guru, yang tdak memahami kebuuhan dari siswa tersebut, baik dalam karakteristik maupun dalam pengembangan ilmu. Dalam hal ini, peran seorang guru sebagai pengembang ilmu sangat besar untun memilih dan melaksanakan pembelajaran yang tepat dan efisiensi bagi peserta didik. Jadi bukan hanya menerapkan pembelajaran berbasis konvensional. Pembelajaran yang baik dapat ditunjang dari suasana pembelajaran yang kondusif. Selain itu, hubungan komunikasi antara guru dan siswa dapat berjalan dengan baik.

Menurut paradigma behavioristik, belajar merupakan transmisi pengetahuan dari expert ke novice. Berdasarkan konsep ini, peran guru adalah menyediakan dan menuangkan informasi sebanyak-banyaknya kepada siswa. Guru mempresepsi diri berhasil dalam pekerjaannya apabila dia dapat menuangkan pengetahuan sebanyak-banyaknya kepada siswa dan siswa dipresepsi berhasil apabila mereka tunduk menerima pengetahuan yang dituangkan oleh guru. Praktek pendidikan 
yang berorientasi semacam itu adalah bersifat indoktrinasi sehingga akan berdampak pada penjinakan kognitif para siswa, menghalangi perkembangan kreativitas siswa, dan memenggal peluang siswa untuk mencapai higher order thinking.

Akhir-akhir ini, konsep belajar diidekati menurut paradigma konstruktivisme. Menurut paham konstruktivistik, belajar merupakan hasil konstruksi sendiri (pebelajar) sebagai hasilinteraksinya terhadaplingkungan belajar. Pengkonstruksian pemahahman dalam belajar dapat melalui proses asimilasi dan akomodasi. Secara hakiki, asimilasi dan akomodasi terjadi sebagai usaha pebelajar untuk menyempurnakan atau mengubah pengetahuan yang telah ada dibenaknya (Heinich, et.al., 2002). Pengetahuan yang telah dimiliki oleh pebelajar sering pula diistilahkan sebagai prakonsepsi. Proses asimilasi dapat terjadi apabila terdapat kesesuaian antara pengalaman baru dengan prakonsepsi yang dimiliki pebelajar. Sementara itu, proses akomodasi adalah suatu proses adaptasi, evolusi, atau perubahan yang terjadi sebagai akibat pengelaman baru pebelajar yang tidak sesuai dengan prakonsepsnya.

Tinjauan filosofi, psikologi kognitif, psikologi sosial, dan teori sains sepakat menyatakan bahwa belajar merupakan suatu proses perubahan (Dole \& Sinatra, 1998). Siswa sendiri yang melakukan perubahan tentang opengetahuaannya. Peran guru dalam pebemlajaran adalah sebagai fasilitator, mediator, dan pembimbing. Jadi, guru hanya dapat membantu prose perubahan pengetahuan dikepala siswa melalui perannya menyiapkan scaffolding dan guiding. Dengan sempurna dibandingkan dengan pengetahuan sebelumnya. Dengan perkataan lain, guru menyiapakan tangga yang efektif, tetapi siswa sendiri yang 


\section{MEMBANGUN MULTIMEDIA INTERAKTIF}

memanjat melalui tangga tersebut untuk mencapai pemahaman yang lebih dalam.

Berdasarkan paradigma konstruktivisme tentang belajar tersebut, prinsip mediated instruction menempati posisi cukup strategis dalam rangka mewujudkan proses belajar secara optimal. Proses belajar yang optimal merupakan salah stu indikator untuk mewujudkan hasil belajar peserta didik yang optimal pula. Hasil belajar yang optimal juga merupakan salah satu cerminan hasil pendidikan yang berkualitas. Pendidikan yang berkualitas memerlukan sumberdaya guru yang mampu dan siap berperan secara profesional dalam lingkungan sekolah dan masyarakat (Heinich et.al., 2002; Ibrahim, 1997; Ibrahim et.al., 2001). Dalam era perkembangan iptek yang begitu pesat, profesionalisme guru tidak cukup hanya dengan kemampuan membelajarkan siswa, tetapi juga harus mampu mengelola informasi dan lingkungan untuk memfasilitasi kegiatan belajar siswa (Ibrahim, et.al., 2001). Konsep lingkungan meliputi tempat belajar, metode, media, sistem penilaian, serta sarana dan prasarana yang diperlukan untuk mengemas pembelajaran dan mengatur bimbingan belajar sehingga memudahkan siswa belajar.

Dampak perkembangan iptek terhadap proses pembelajaran adalah diperkayanya sumber dan media pembelajaran, seperti buku teks, modul, overhead transparansi, film, video, televisi, slide, hypertext, dan web. Guru frofesional dituntut mampu memilih dan menggunakan berbagai jenis media peembelajaran yang ada disekitarnya. 


\section{Pengertian Media Pembelajaran}

\section{a. Definisi Media Pembelajaran}

Banyak batasan yang diberikan orang tentang definisi media. Batasan tersebut lebih diarahkan pada media pembelajaran yang digunakan di lembaga formal. Yudhi Munadi (2008: 6) mengemukakan bahwa kata "media" adalah bentuk jamak dari "medium", yang berasal dari bahasa latin "medius", yang berarti "perantara" dalam bahasa Indonesia. Dalam bahasa Arab, media disebut "wasail" bentuk jama' dari "wasilah" yakni sinonim al-wasth yang artinya juga 'tengah'. Kata 'tengah itu sendiri berarti di antara dua sisi, maka disebut juga sebagai 'perantara' (wasilah) atau yang mengantarai kedua sisi tersebut. Karena posisinya berada di tengah, ia bisa juga disebut sebagai pengantar atau penghubung, yakni yang mengantarkan atau menghubungkan atau menyalurkan suatu hal dari satu sisi ke sisi lainnya. Menurut Association of Education and Communication Technology (AECT) dalam Arif S. Sadiman, dkk (2006:6) mengatakan bahwa media merupakan bentuk dan saluran yang digunakan orang untuk menyalurkan pesan/informasi. Sedangkan menurut Azhar Arsyad (2009:4) apabila media membawa pesan-pesan atau informasi yang bertujuan instruksional atau mengandung maksud-maksud pengajaran maka media itu disebut media pembelajaran.

Menurut Gerlach dan Ely dalam Azhar Arsyad (2009: 12-14) , ciri-ciri media ada tiga, yaitu: 


\section{Ciri Fiksatif (Fixative Property)}

Ciri ini menggambarkan kemampuan media merekam, menyimpan, melestarikan, dan merekonstruksi suatu peristiwa atau obyek.

2. Ciri Manipulatif (Manipulatif Property)

Transformasi suatu kejadian atau obyek dimungkinkan karena media memiliki ciri manipulatif. Kejadian yang memakan waktu berhari-hari dapat disajikan kepada siswa dalam waktu dua atau tiga menit dengan teknik pengambilan gambar time-lapse recording.

3. Ciri Distributif (Distributive Property)

Ciri distributif dari media memungkinkan suatu obyek atau kejadian ditransportasikan melalui ruang, dan secara bersamaan kejadian tersebut disajikan kepada sejumlah besar siswa dengan stimulus pengalaman yang relatif sama mengenai kejadian itu.

Sedangkan manfaat penggunaan media menurut Azhar Arsyad (2009: 25-27) antara lain:

1. Media pembelajaran dapat memperjelas penyajian pesan dan informasi sehingga dapat memperlancar serta meningkatkan proses maupun hasil belajar.

2. Mediapembelajarandapatmeningkatkandanmengarahkan perhatian anak sehingga dapat menimbulkan motivasi belajar, interaksi yang lebih langsung antara siswa dan lingkungannya, dan kemungkinan siswa untuk belajar sendiri-sendiri sesuai dengan kemampuan dan minatnya. 
3. Media pembelajaran dapat mengatasi keterbatasan indera, ruang, dan waktu.

4. Media pembelajaran dapat memberikan kesamaan pengalaman kepada siswa tentang peristiwa-peristiwa di lingkungan mereka, serta memungkinkan terjadinya interaksi langsung dengan guru, masyarakat, dan lingkungannya, misalnya melalui karyawisata, kunjungan-kunjungan ke museum atau kebun binatang.

Pemanfaatan media merupakan hal yang tak terpisahkan dalam pembelajran di sekolah. Pemanfaatan media merupakan upaya kreatif dan sistematis dari seorang guru untuk menciptakan pengalaman belajar kepada siswa. Sudarsono (2004:6-7) mengungkapkan peran pokok media dalam dunia pendidikan yaitu: (1) berfungsi unutk memberikan pengalaman yang konkret kepada siswa; (2) berfungsi sebagai sarana komunikasi dan interaksi antarasiswa dengan media tersebut, dan dengan demikian merupakan sumber belajar yang penting. Manfaat pemakaian media dalam pembelajaran disampiakan kemp (1985:3) beberapa hasil penelitian yang menunjukan dampak positif terhadap pemakaian media antara lain: penyampaian pelajaran menjadi lebih baku, pembelajaran lebih menarik, pembelajaran lebih interaktif, efisien waktu, kualitas belajar dapat ditingkatkan, pembelajaran dapat diberikan dimanapun dan kapanpun, mengembangkan sikap positif siswa dan peran guru dapat berubah kearah yang positif.

Didalam pemilihan media maka perlu dipertimbangkan mengenai kualotas dari media tersebut. 
Menurut depdiknas (2005:9) bahwa kualitas media pembelajaran tampak dari: (a) dapat menciptakan pengalaman belajar, (b) mampu memfasilitasi proses interaksi antara mahasiswa dan dosen, mahasiswa dan mahasiswa, mahasiswa dan ahli bidang ilmu yang relevan, (c) media belajar dapat memperkaya pengalaman belajar mahasiswa, serta (d) melalui media mampu mengubah suasana belajar dari mahasiswa pasif dan dosen sebagai sumber ilmu satu satunya, menjadi mahasiswa katif berdiskusi dan mencari informasi melalui berbagai sumber belajar yang ada.

Media pembelajaran menurut Kemp ( 1985:28) dapat memenuhi tiga fungsi utama apabila media dipakai untuk perorangan, kelompok atau kelompok pendengar yang besar jumlahnya, yaitu: (1) memotivasi minat atau tindakan, (2) menyajikan informasi, (3) memberi instruksi. Untuk memenuhi memotovasi media dapat direlaisasikan dengan teknik drama atau hiburan. Untuk tujuan informasi dapat dipergunakan untuk menyajikan informasi dihadapan sekelompokj siswa. Serta fungsi meberi instruksi dimana informasi yang terdapat dalam media harus melibatkan siswa. Pemilihan media yang tepat sasaran dapat mendukung peningkatan kualitas pembelajaran apabila dipadu dengan perilaku pendidik yang berkualitas, perilaku peserta didik yang positif, iklim pembelajaran yang mendukung, dan tercukupinya materi pembelajaran. Semua komponen yang ada saling mendukung agar terciptanya proses pembelajaran yang efektif, efisien, menyenangkan serta bermakna. 
Dalam kegiatan interaksi antara siswa dan lingkungan, fungsi media dapat diketahui berdasarkan adanya kelebihan media dan hambatan yang mungkin timbul dalam proses pembelajaran. Tiga kelebihan kemampuan media (Gerlach \& Ely dalam Ibrahim, et.al., 2001) adalah sebagai berikut.

Pertama, Kemampuan fiksatif, artinya dapat menangkap, menyimpan, dan menampilkan kembali suatu obyek atau kejadian. Dengan kemampuan ini, obyek atau kejadian dapat digambar, dipotret, direkam, difilmkan, kemudian dapat disimpandan pada saat diperlukan dapat ditunjukkan dan amati kembali seperti kejadian aslinya.

Kedua, Kemampuan manipulatif, artinya media dapat menampilkan kembali obyek atau kejadian dengan berbagai macam perubahan (manipulasi) sesuai keperluan. Misalnya, diubah ukurannya, kecepatannya, warnanya, dan dapat pula diulangulang penyajiannya.

Ketiga, Kemampuan distributif, artinya media mampu menjangkau audiens yang besar jumlahnya dalam satu kali penyajian secara serempak, misalnya TV atau Radio.

Hambatan-hambatan komunikasi dalam proses pembelajaran adalah sebagai berikut:

Pertama, Verbalisme, artinya siswa dapat menyebutkan kata tetapi tidak mengetahui artinya. Hal ini terjadi karena biasanya guru mengajar hanya dengan 
penjelasan lisan (ceramah), siswa cenderung hanya menirukan apa yang dikatakan guru.

Kedua, Salah tafsir, artinya dengan istilah atau kata yang samadiartikan berbeda oleh siswa. Hal ini terjadi karena biasanya guru hanya menjelaskan secara lisan, tanpa menggunakan media pembelajaran yang lain, misalnya gambar, bagan, model dan sebagainya.

Ketiga, Perhatian tidak terpusat, Hambatan tersebut dapat terjadi karena beberapa hal, antara lain gangguan fisik, ada hal lain yang lebih menarik dan memengaruhi perhatian siswa, siswa melamun, cara mengajar guru membosankan, cara menyajikan bahan pelajaran tanpa variasi, serta kurang adanya pengawasan dan bimbingan guru.

Keempat, Tidak tejadinya pemahaman, artinya kurang memiliki kebermaknaan logis dan psikologis. Apa yang diamati atau dilihat, dialami secara terpisah. Tidak terjadi proses berpikir yang logis mulai dari kesadaran hingga timbulnya konsep.

Pengembangan media pembelajaran hendaknya diupayakan untuk memanfaatkan kelebihan-kelebihan yang dimiliki oleh media tersebut dan berusaha menghindari hambatan-hambatan yang mungkin muncul dalam proses pembelajaran. Secara rinci, fungsi media dalam proses pembelajaran adalah sebagai berikut.

1. Menyaksikan benda yang ada ataunperistiwa yang terjadi pada masa lampau. Dengan perantaraan gambar, potret, slide, film, video, atau media yang lain, siswa 
dapat memperoleh gambaran yag nyata tentang benda atau peristiwa sejarah.

2. Mengamati benda atau peristiwa yang sukar dikunjungi, baik karena jaraknya jauh, berbahaya, maupun terlarang. Misalnya, video tentang kehidupan harimau dihutan, keadaan dan kesibukan di pusat reaktor nuklir, dan sebagainya.

3. Memperoleh gambaran yang jelas tentang benda atau halhal yang sukar diamati secara langsung karena ukurannya yang tidak memungkunkan. Misalnya, dengan perantaan paket, siswa dapat memperoleh gambaran yang jelas tentang bendungan dan kompleks pembangkitan listrik; dngan slide dan film siswa dapat memperoleh gambaran tentang bakteri, amuba, dan sebagainya.

4. Mendengar suara yang sukar ditangkap dengan telinga secara langsung. Misalnya, rekaman suara denyut jantung dan sebagainya.

5. Mengamati dengan teliti binatang-binatang yang sukar diamati secara langsung karena sukar ditangkap. Dengan bantuan gambar, potret, slide, film atau video, siswa dapat mengamati berbagai macam serangga, burung hantu, kelelawar, dan sebagainya.

6. Mengamati peristiwa-peristiwa yang jarang terjadi, atau berbahaya untuk didekati. Dengan slide, film, atau video siswa dapat mengamati pelangi, gunung meletus, pertempuran, dan sebagainya.

7. Mengamati dengan jelas benda-benda yang mudah rusak atau sukar diawetkan. Dengan menggunakan model 
atau benda tiruan, siswa dapat memperoleh gambaran yang jelas tentang organ-organ tubuh manusia seperti jantung, paru-paru, alat penceranaan, dan sebagainya.

8. Dengan mudah membandingkan sesuatu. Dengan bantuan gambar, model, ataupun foto, siswa dapat dengan mudah membandingkan dua benda yang berbeda sifat ukuran, warna, dan sebagainya.

9. Dapat melihat secara cepat suatu proses yang berlangsung secara lambat. Dengan video, proses perkembangn katak dari telur sampai menjadi katak dapat diamati dalam waktu hanya beberapa menit. Bunga dari kucup sampai mekar yang berlangsung beberapa hari, dengan bantuan film dapat diamati hanya dalam beberapa detik.

10. Dapat melihat secara langsung gerakan-gerakan yang berlangsung secara cepat. Dengan bbantuan film atau video, siswa dapat mengamati dengan jelas gaya lompat tinggi, teknik loncat indah, yang disajikan secar lambat atau pada saat tertentu dihentikan.

11. Mengamati gerakan-gerakan mesin atau alat yang sukar diamati secara langsung. Dengan film atau video dapat dengan mudah siswa mengamati jalannya mesin 4 tak, 2 tak, dan sebagainya.

12. Melihat bagian-bagian yang tersembunyi dari suatu alat. Dengan diagram, bagan, model, siswa dapat mengamati bagian mesin yang sukar diamati secara langsung.

13. Melihat ringkasan dari suatu rangkaian pengamatan yang panjang atau lama. Setelahh siswa melihat proses 
penggilingan tebu atau dipabrik gula, mereka juga dapat mengamati secara ringkas proses penggilingan tebu yang disajikan dengan menggunakan film atau video (memantapkan hasil pengamatan).

14. Dapat menjangkau aidien yang besar jumlahnya dan mengamati suatu obyek secara serempak. Dengan siaran radio atau televisi, ratusan bahkan ribuan mahasiswa dapat mengikuti kuliah yang disajikan seorang profesor dalam waktu yang sama.

15. Dapat belajar sesuai dengan kemampuan, minat, dantemponya masing-masin g. Dengan modul atau pengajaran berprogram, siswa dapat belajar sesuai dengan kemampuan, kesempatan, dan kecepatan masing-masing.

\section{b. Jenis Jenis Media Pembelajaran}

Banyak jenis media pembelajaran yang dijumpai di lingkungan pendidikan dan di lingkungan sosial. Ada media yang dibuat oleh pendidik, oleh pabrik maupun yang sudah tersedia di lingkungan yang langsung dapat dimanfaatkan untuk menunjang kegiatan pembelajaran maupun media yang secara khusus sengaja dirancang untuk keperluan pembelajaran. AECT (1977:8) menyatakan bahwa sumber belajar yang mencakup media dibedakan menjadi dua jenis, yakni: (1) resouces by design, sumber-sumber yang secara khusus telah dikembangkan sebagai komponen sistem instruksional untuk memberikan kemudahan belajar yang terarah dan bersifat formal; dan (2) resources by utilization, sumber-sumber yang tidak secara khusus 
dirancang untuk keperluan pembelajaran namun dapat ditemukan,diaplikasikan, dan digunakan untuk keperluan belajar.

Pada hakikatnya media merupakan salah satu komponen sistem pembelajaran. Sebagai komponen sistem pembelajaran, media hendaknya merupakan bagian integral dan harus sesuai dengan proses pembelajaran secara menyeluruh. Ujung dari pemilihan media adalah penggunaan media dalam kegiatan pembelajaran sehingga memungkinkan peserta didik dapat berinteraksi dengan media yang dipilih. Banyak jenis media yang dapat digunakan dalam kegiatan pembelajaran. Beberapa jenis media (visual) biasanya digunakan pada saat kegiatan pembelajaran sedang berlangsung adalah gambar, ilustrasi fotografi, grafik, kartun, sketsa, diagram dan lain lain. Romiszowski (1974:92-93) membagi alat bantu visual menjadi tiga bentuk, yakni: (1) gambar meliputi fotografi, garis, dan lukisan sebagai representasi objek riil, (2) diagram meliputi gambar mekanik, contoh representatif, diagram alur, dan diagram skematis sebagai representasi suatu objek, ciri objek, proses, konsep, atau fenomena; dan (3) grafik meliputi grafik dan bagan sebagai reprsentasi suatu kecenderungan, antar hubungan, atau sekumpulan bentuk objek.

Media pemebalajaran diklasifikasi berdasarkan tujuan pemakai dan karakteristik jenis media. Terdapat lima model klafikasi, yaitu menurut : (1) Wilbur Schramm, (2) Gagne, (3) Allen, (4) Gerlach dan Ely, dan (5) Ibrahim. 
Menurut Schramm, media digolongkan menjadi media rumit. Mahal, dan sedarhana. Schramm mengempokan media menurut kemampuan daya liutan, yaitu : (1) liputan luas dan serentak seprti TV, radio, faksmile ;2) liputan terbatas pada ruang, seperti film, video, slide, poster audio tape; (3) media untuk belajar individual, seperti buku, modul, program belajar dengan komputer dan telponon.

Menurut Gagne, media klarifikasi menjadi tujuh kelompok, yaitu benda untuk didemontrasikan, komunikasi lisan, media cetak, gamabar diam, gamabar bergerak, flim bersuara, dan mesin belajar. Ketujuh kelompok media pembelajaran tersebut dikaitkan dengan kemempuannya memenuhu fungsi menurut hirarki belajar yang di kembangakan, yaitu pelontar stimulasi belajar, penarik minat belajar, contoh prilaku belajar, memberi kondisi ekternal, menuntun cara berfikir, mamasukan alih ilmu, menilai prestasi, dan memberi umpan balik.

Menurut Allen, terdapat sembilan kelompok media, yaitu : visual diam, film, televisi, objek tiga dimensi, rekaman, pelajaran teprogram, demontrasi, buku teks cetak, dan sajian lisan. Di samping mengklasifikasikan, Allen juga mengkaitkan antara jenis media pemelajaran dan tujuan pembelajaran yang akan di capai. Allen melihat bahwa media tertentu memiliki kelebihan untuk tujuan belajar tertentu, tetapi lemah untuk tujuan belajar lain. Allen mengungkapkan tujuan belajar, antara lain : info faktual, pengenalan visual, prinsip dan konsep, prosedur keterampilan, dan sikap. Setiap jenis media tersebut 
memiliki perbedaan kemampuan untuk mecapai tujuan belajar, ada tinngi, sedang, dan rendah.

Menurut Gerlach dan Ely, media di kelompokan berdasarkan ciri-ciri fisiknya atas delapan kelompok, yaitu benda sebenarnya, presentasi verbal, presentasi grafis, gamabr diam, gamabr bergerak, rekaman suara, pengajaran program, dan simulasi.

Menurut Ibrahim, media dikelompokan berdasarkan ukuran dan kompleks tidaknya alat dan perlengkapannya atas lima kelompok, yaitu media tanpa proyeksi dua dimensi: media tanpa proyeksi tiga dimensi : aoudio, proyeksi, televisi, video, dan komputer.

Berdasarkan pemahaman atas klasifikasi media pembelajaran tersebut, akan mudah para guru atau praktis lainnya dalam melakukan pemilihan media yang tepat pada waktu merencanakan pemeblajaran untuk mencapai tujua tertentu. Pemilihan media yang di sesuaikan dengan tujuan, materi, serta kemampuan dan karakteristik pembelajara, akan sangat menunjang efesiensi serta efektifitas proses dan hasil pembelajaran.

\section{c. Media Pembelajaran Berbantuan Komputer}

pembelajaran berbantuan computer (PBK) atau dikenal dengan istilah computer assisted instruction merupakan suatu proses penyampaian program pembelajaran dengan menggunakan bantuan computer. Dengan kata lain, PBK merujuk pada sgala sesuatu dimana isi atau kegiatan pembelajaran dimediasi oleh computer. Isi atau program PBK tentu dirancang dengan baik agar peserta didik dapat memahaminya dengan mudah.Dalam 
arti luas, PBK ialah penggunaan computer secara langsung denga peserta didik untuk menyampaikan materi pelajaran, meberikan latihan dan mengetes kemampuan belajar peserta didik (Anderson, 1987:199).

Definisi yang lebih sederhana dikemukakan oleh Hannafin dan Peck (1988:383) yang menyatakan bahwa PBK merupakan aplikasi teknologi computer untuk memecahkan masalah pembelajaran.Dilihat dari situasi belajar, komputer sebagai alat bantu pembelajaran digunakan untuk tujuan menyajikan isi pelajaran dapat berbentuk tutorial, drills and practice, simulasi dan permainan.

1. Tutorial

Program pengajaran tutorial dengan bantuan komputer meniru sistem tutor yang dilakukan oleh instruktur.Informasi atau pesan berupa suatu konsep disajikan di layar komputer dengan teks, gambar atau grafik.Setelah pengguna diperkirakan telah membaca, menginterpretasi, dan menyerap konsep itu, suatu pertanyaan atau soal diajukan. Jika jawaban pengguna benar, komputer akan melanjutkan penyajian informasi atau konsep berikutnya. Jika jawaban salah, komputer dapat kembali ke informasi konsep sebelumnya atau pindah ke salah satu dari beberapa penyajian informasi konsep remidial yang ditentukan oleh jenis kesalahan yang dibuat oleh pengguna.

Format sajian ini merupakan multimedia pembalajaran yang dalam penyampaian materinya dilakukan secara tutorial, sebagaimana layaknya tutorial yang dilakukan oleh guru atau instruktur. Informasi yang 
berisi suatu konsep disajikan dengan teks, dan gambar, baik diam maupun bergerak dan grafik.

Pada saat yang tepat, yaitu dianggap bahwa penggunaan telah membaca, menginterprestaikan dan menyerap konsep itu, diajukan serangkai pertanyan atau tugas. Jika konsep itu, diajukan serangkai pertanyaan atau tugas. Jika jawaban atau respon pengguna benar, kemudian dilanjutkan materi berikutnya. Jika jawaban atau respon pengguna salah, pengguna harus mengulang memahami konsep tersebut secara keseluruhan atau pun pada bagian-bagain tertentu saja (remedial). Kemudian, pada bagian akhir biasanya akan diberikan serangkaian pertanyaan yang merupakan tes untuk mengukur tingkat pemahaman pengguna atas konsep atau materi yang disampaikan.

2. Drills and Practice (Latihan)

Latihan untuk meningkatkan keterampilan atau memperkuatpenguasaan konsepdapat dilakukandengan drills and practice. Komputer menyiapkan serangkaian soal atau pertanyaan yang serupa dengan yang biasa ditemukan dalam buku. Format ini dimaksudkan untuk melatih pengguna sehingga mempunyai kemahiran di dalam suatu keterampilan atau memperkuat penguasaan terhadapat suatu konsep. Program ini juga menyediakan serangkaian soal atau pertanyaan yang biasanya ditampilkan secara acak sehingga setiap kali digunakan maka soal atau pertanyaan yang tampil akan selalu berbeda, atau paling tidak dalam kombinasi yang berbeda. 
Program ini juga dilengkapi dengan jawaban yang benar, lengkap dengan penjelasaannya sehingga diharpakan pengguna akan dapat pula memahami suatu konsep tertentu. Pada bagian akhir, pengguna juga dapat melihat skor terkahir yang di capai, sebagai indikator untuk mengukur tingkat keberhasilan dalam memecahkan soal-soal yang diajurkan.

3. Simulasi

Multimedia pembelajaran dengan format ini mencoba menyamai proses dinamis yang terjadi di dunia nyata. Misalnya, untuk mensimulasikan pesawat terbang, pengguna seolah-olah melakukan aktivitas menerbangkan pesawat terbang. Selain itu peserta didik dapat mensimulasikan usaha kecil atau menegndalikan pembakit listrik tenaga nuklir. Pada dasarnya, format ini mencoba meberikan pengalaman masalah dunia nyata yang biasanya berhubungan dengan suatu resik, seperti pesawat yang akan jatuh atau menabrak, perusahaan akan bangkrut, atau terjadi malapetaka nuklir.

\section{Permainan Instruksional}

Program permainan yang dirancang dengan baik dapat memotivasi siswa dan meningkatkan pengetahuan dan keterampilannya.Permainan instruksional menggabungkan aksi-aksi permainan video dan keterampilan penggunaan papan ketik pada komputer. Siswa dapat menjadi terampil mengetik karena dalam permainan siswa dituntut untuk menginput data dengan mengetik jawaban atau perintah dengan benar. Tentu 
saja bentuk permainan yag disajikan disini tetap mengacu pada proses pembelajaran. Dengan program multimedia berformat ini, diharapkan terjadi aktivitas belajar sambil bermain. Dengan demikian, pengguna tidak merasa bahwa mereka sesungguhnya sedang belajar.

Media pembelajaran yang menggunakan banyak media, dikenal sebagai media pembelajaran berbasis multimedia. Multimedia dibuat dengan menggunakan banyak perangkat lunak yang dapat mengolah teks, seperti Microsoft Office Family atau Note Pad; mengolah gambar seperti Corel Draw, Microsoft Visio, dan Adoble Photoshop; mengolah animasi,baik animasi teks maupun animasi gambar seperti Macromedia Family (Flash Freehand, Authorware, Dreamweaver), 3D Maxdan Swish; mengolah suara, seperti Cool Edit Pro, dan Audio Studio; mengolah video seperti Windows Moviemaker, dan VCD Cutter dan digabungkan menjadi satu dengan programprogram authoring (authoring tool) seperti Macromedia Autuware, Dreamweaver, Visual Basic, dan Delphi.

Media pembelajaran berbasis multimedia haruslah mudah digunakan dan memuat navigasinavigasi sederhana sehingga memudahkan pengguna. Selain itu harus menarik agar merangsang pengguna tertarik menjelajah seluuruh program, sehingga seluruh materi pembelajaran yang terkandung didalamnya dapat terserap dengan baik. Materi pembelajaran yang terkandung didalamnya juga harus disesuaikan dengan kebutuhan pengguna, sesuai dengan kurikulum dan mengandung banyak manfaat. 
Media pembelajaran berbasis multimedia tersebut juga harus mudah peng-instal-annya pada komputer, dan tidak memerlukan CD dalam menjalankannya. Dengan kemudahan tersebut, membuat pengguna merasa lebih praktis dan penyebarannya akan lebih luas.

\section{Percobaan atau Ekperimen}

Format ini mirip dengan format simulasi, namun lebih di tunjukan pada kegiatan-kegiatan yang bersifat ekperimen, seperti kegiatan praktikum di laboraturium IPA, biologi atau kimia. Program menyedikan serangkaiann peralatan dan bahan, kemudian pengguna dapat melakukan percobaan atau eksperimen sesuai petunjuk. Setelah itu, mengembangkan eksperimeneksperimen lain berdasarkan petunjuk tersebut. Diharapkan pada akhirnya pengguna dapat menjelaskan suatu konsep atau fenomena tertentu berdasarkan eksperimen yang mereka lakukan secara maya tersebut.

Keberhasilan penggunaan komputer dalam pengajaran sangat tergantung pada berbagai faktor seperti proses dan motivasi dalam belajar. Oleh karena itu, para ahli telah mencoba untuk mengajukan prinsip-prinsip perancangan pembelajaran berbantuan komputer. Agar efektif, perlu diperhatikan hal-hal sebagai berikut (Azhar Arsyad, 2009: 166-169):

1. belajar harus menyenangkan

2. interaktif

3. kesempatan berlatih harus memotivasi, cocok, dan tersedia feedback

4. menuntun dan melatih siswa dengan lingkungan informal. 
Dengan adanya media berbasis komputer, sekolah lebih mudah beradaptasi dengan perkembangan terakhir dunia pendidikan melalui model e-education.

Terdapat istilah yang spesifik bagi suatu paket pembelajaran berbasis komputer,yaitu CAI (Computer Assisted Instruction), CAL (Computer Assisted Learning),dan CBL (Computer Based Learning). Sangat penting bagi seorang pengembang multimedia pembelajaran untuk mengetahui makna dari istilah-istilah seperti CAI, CAL, dan CBL. Pemahaman akan istilah-istilah ini penting dalam menentukan paket mana yang akan dikembangkan dan instruksi seperti apa yang akan diberikan. CAI, secara umum, bermakna instruksi pembelajaran dengan bantuan komputer yang memiliki karakteristik yang khas : menekankan belajar mandiri, interaktif, dan menyediakan bimbingan. CAL memiliki arti dan karakteristik yang senada dengan CAI. Sekalipun disini CAI atau CAL menekankan belajar mandiri, hal ini tidak serta merta menunjukkan bahwa CAI atau CAL merupakan suatu medium utama dalam pembelajaran. Pada kenyataannya CAI atau CAL lebih banyak berfungsi sebagai medium pengayaan (enrichment) bagi medium utama, baik medium utama tersebut adalah guru yang mengajar di depan kelas atau buku pelajaran utama yang wajib dibaca oleh siswa. Sementara CBL, sesuai dengan namanya, menunjukkan bahwa komputer dipakai sebagai medium utama dalam memberikan pembelajaran. Pada CBL, sebagian besar kandungan dari pembelajaran (the bulk of the content) memang disampaikan melalui medium komputer. CBL cocok diberikan pada kasus pendidikan 
jarak jauh. Perbedaan arti dari CAI, CAL dan CBL ini tentu saja mempengaruhi desain instruksional yang dirancang bagi paket-paket tersebut (Gatot Pramono, 2010:3).Dari pengertian tersebut, maka penelitian pengembangan ini termasuk dalam CAI (Computer Assisted Instruction) yang menekankan pada pembelajaran interaktif.

\section{Pengertian Multimedia Interaktif}

Panduan untuk memahami mengenai multimedia dapat diwalai dari pemahaman mengenai definisi multimedia.Berbagai pendapat mengenai definisi multimedia telah banyak disampaikan oleh para ahli, oleh karena itu kita perlu menyimak berbagai batasan pengertian tentang multimedia tersebut.

Multimedia yang dimanfaatkan dalam bidang pendidikan khususnya dalam kegiatan pembelajaran disebut dengan multimedia pembelajaran.Jadi multimedia pembelajaran merupakan penyajian materi ajar kepada peserta didik dengan memanfaatkan berbagai media melalui teknologi computer. Oleh karena itu, dalam konteks pemleajaran istilah multimedia diartikan sebagai "an educational presentation made using primarily audio and images" (Mitchell,2003).

Media pembelajaran yang baik harus dapat membuat peserta didik aktif dalam proses pembelajaran. Gabungan atau perpaduan dari berbagai media yang terdiri dari teks, grafis, gambar diam, animasi, suara, dan video untuk menyampaikan pesan kepada publik dinamakan multimedia (bambang Warsita, 2008:153). 
Teknologi komputasi multimedia merupakan suatu era baru dalam dunia informasi modern yang telah berkembang pesat beberapa tahun terakhir ini. Multimedia mampu menciptakan sistem komunikasi yang interaktif antara pemakai komputer dengan komputer itu sendiri. Pendapat lain tentang multimedia dikemukakan oleh ahli lain yaitu Bruder dalam Snyder (2006:179) bahwa "...the coordinated combination of video, sound, text, animation, and graphics". Sementara Heinich (1996:260) mendefinisikan multimedia sebagai kombinasi dua atau lebih format media yang dipadukan secara integrative sehingga menghasilkan program informasi atau program pendidikan.

Aneka media tersebut digabungkan menjadi satu kesatuan kerja yang akan menghasilkan suatu informasi yang memiliki nilai komunikasi yang sangat tinggi, artinya informasi tidak hanya dapat dilihat sebagai hasil cetakan, melainkan juga dapat didengar, membentuk simulasi dan animasi yang dapat membangkitkan selera dan memiliki nilai seni grafis yang tinggi dalam penyajiannya.

Multimedia melibatkan perangkat keras dan perangkat lunak. Perangkat keras menurut Suyanto (2005:51) adalah alat pengolah data (teks,gambar, audio, video dan animasi) yang bekerja secara elektronis dan otomatis. Perangkat keras dapat bekerja apabila ada unsure manusia yang mengerti tentang alat itu dan dapat bekerja menggunakan alat itu juga karena multimedia adalah suatu sistem.Sistem perangkat keras terdiri dari 4 unsur utama, dan satu unsure tambahan. Keempat unsure tersebut adalah in put unit, central processing unit (CPU), storage / memory, 
dan output unit. Sedangkan yang berupa unsure tambahan adalah communication link. Hal senada diungkapkan oleh Heinich (1996:247) bahwa perangkat keras multimedia terdiri dari: input device, CPU, memory, storage and output device.

Dengan menggunakan perangkat lunak, multimedia computer dapat juga dimanfaatkan untuk mebuat program program presentasi yang dibuat dengan menggunakan program khusus.Seperti yang diungkapkan oleh Suyanto (2005:103) prangkat lunak multimedia adalah komponen kokponen dalam data processing system, berupa program program yang mengontrol bekejanya sistem multimedia. Pada umunya istilah perangkat lyunak multimedia menyatakan cara cara yang menghasilkan hubungan yang lebih efisien antara manusia dan mesin computer multimedia. Senada dengan itu Newbey (2000:102) mengatakan bahwa computer software is the programs or instruction that tell computer to do. Fungsi perangkat lunak multimedia computer antara lain mengidentifikasi program multimedia dan menyiapkan aplikasi program multimedia sehingga tata kerja seluruh peralatan computer multimedia jadi terkontrol serta mengatur dan membuat pekerjaan menjadi lebih efisien. Afrizal Mayub (2005:2) juga mengungkapkan bahwa perangkat lunak media belajar berbantuan computer dapat dibagi dalam dua kelompok, yaitu sistem authoring dan sistem multimedia.Sistem authoring adalah sistem program yang memungkinkan seorang guru menysusun materi ajar tanpa menguasai suatu bahsa pmrograman.Hal ini berbeda dengan perangkat multimedia yang menuntuk untuk menguasai bahasa perograman. 
Istilah multimedia indentik dengan computer multimedia, yaitu computer yang memiliki kemampuan olah data, olah kata, olah gambar, dan olah gerak dimana masing maisng unsure tersebut saling melengkapi, menunjang, dan saling membantu. Menurut Ariesto (2003:3) bahwa suatu computer multimedia adalah computer yang mempunyai alat output seperti biasanya yaitu alat display dan hardcopy, dengan rekaman audio berkualitas tinggi, image yang berkualitas tinggi, animasi dan rekaman video. Gafur (2001:91) menunjukan tentang cirri khas computer multimedia sebagai produk teknologi komunikasi mutakhir, antara lain: CPU dengan kapasitas memory yang tinggi, hardisk dengan daya tamping yang besar serta dilengkapi dengan brbagai macam perangkat peripheral (pendukung computer). Dengan kapasitas yang demikian besar, computer multimedia dapat menampilkan berbagai jenis pesan seperti kata, gambar mati, gambar bergerak, warna, gambar tiga dimensi, dan suara baik secara sendiri sendiri maupun secara simultan. Dengan kemampuan multimedia akan mampu menarik indera dan menarik minat belajar, karena perpaduan antara pandangan, suara dan gerakan mampu menyampaikan pesan secara menarik.

Dengan demikian multimedia adalah teknologi yang mengoptimalkan pemanfaatan computer untuk membuat, menampilkan dan merekayasa teks, grafik, audio, gambar bergerak (animasi), video dalam satu kemasan program dengan menggabungkan link dan tool yang memungkinkan pemakai untuk bernavigasi, beriteraksi, berkreasi dan berkomunikasi. Dari sini terkandung ada empat komponen 
multimedia yaitu, harus ada computer, link, alat navigasi, dan tersedianya tempat untuk mengumpulkan, memproses serta mengkomunikasikan informasi. Dengan tampilan yang dapat mengkombinasikan berbagai unsurpenyampaian informasi dan pesan, computer dapat dirancang dan digunakan sebagai tekbologi yang membantu proses pembelajaran.

Rob Phillips menjelaskan makna interaktif sebagai suatu proses pemberdayaan siswa untuk mengendalikan lingkungan belajar. Interaktif disini tidakterlepas dari adanya hubungan timbal balik antara komputer dan pengguna melalui alat-alat perantara seperti monitor, keyboard, mousedan sebagainya (Sunaryo Sunarto, 2009:126).

Teknologi komputasi multimedia mengintegrasikan teks, grafik, suara, animasi dan video untuk menciptakan suatu komunikasi interaktif dari sebuah informasi yang mampu mempengaruhi sebanyak mungkin indera yang dimiliki oleh manusia seperti penglihatan dan pendengaran. Media teks digunakan untuk menciptakan tulisan-tulisan, sedangkan media gambar dan grafik digunakan untuk menciptakan suatu citra yang dapat menerangkan dan berbicara lebih banyak dari tulisan-tulisan yang ada.Tanpa sistem grafis yang baik, tidak mungkin informasi dapat disajikan dalam bentuk diagram, animasi, video maupun teks dengan kualitas tinggi. Disamping itu, penambahan suara dapat lebih menciptakan suasana interaktif bagi pemakainya.

Berbagai pengertian dan penjelasan di atas jika digabungkan akan menjadi pengertian yang saling berhubungan. Adapun pengertian pengembangan media pembelajaran berupa multimedia interaktif adalah proses 
pewujudan suatu sarana yang digunakan sebagai perantara penyampaigagasan atau pemikiran dalam rangka tercapainya proses belajar mengajar yang efektif dan efisien dengan cara mengaktifkan siswa dalam proses pembelajaran.

Richard E. Mayer (2001) mengemukakan tentang sepuluh prinsip desain multimedia pembelajaran, yaitu:

\section{Prinsip ke-1: Prinsip Multimedia}

"Orang belajar lebih baik dari gambar dan kata dari pada sekedar kata-kata saja".

\section{Prinsip ke-2: Prinsip Kesinambungan Spasial}

“Orang belajar lebih baik ketika kata dan gambar terkait disandingkan berdekatan dibandingkan apabila disandingkan berjauhan atau terpisah."

Oleh karena itu, ketika ada gambar yang dilengkapi dengan teks, maka teks tersebut harus merupakan jadi satu kesatuan dari gambar tersebut, jangan menjadi sesuatu yang terpisah.

\section{Prinsip ke-3: Prinsip Kesinambungan Waktu}

"Orang belajar lebih baik ketika kata dan gambar terkait disajikan secara simultan dibandingkan apabila disajikan bergantian atau setelahnya."

Ketika ingin memunculkan suatu gambar dan atau naimasi atau yang lain beserta teks, misalnya, sebaiknya munculkan secara bersamaan alias simultan. Jangan satu-satu, sebab akan memberikan kesan terpisah or tidak terkait satu sama lain.

\section{Prinsip ke-4: Prinsip Koherensi}

"Orang belajar lebih baik ketika kata-kata, gambar, suara, video, animasi yang tidak perlu dan tidak relevan tidak digunakan." 
Banyak sekali pengembang media mencantumkan sesuatu yang tidak perlu.Mungkin maksudnya untuk mempercantik tampilan, memperindah suasana atau menarik perhatian mata. Cantumkan saja apa yang perlu dan relevan dengan apa yang disajikan.

\section{Prinsip ke-5: Prinsip Modalitas Belajar}

"Orang belajar lebih baik dari animasi dan narasi (termasuk video), daripada dari animasi plus teks pada layar."

Jadi, lebih baik animasi atau video plus narasi daripada sudah ada narasi ditambah pula dengan teks yang panjang. Hal ini, sangat mengganggu.

\section{Prinsip ke-6: Prinsip Redudansi}

"Orang belajar lebih baik dari animasi dan narasi (termasuk video), daripada dari animasi, narasi plus teks pada layar (redundan)."

Sama dengan prinsip di atas.Jangan redudansi, kalau sudah diwakili oleh narasi dan gambar/animasi, janganlah tumpang tindih pula dengan teks yang panjang.

\section{Prinsip ke-7: Prinsip Personalisasi}

“Orang belajar lebih baik dari teks atau kata-kata yang bersifat komunikatif (conversational) daripada kalimat yang lebih bersifat formal."

\section{Prinsip ke-8: Prinsip Interaktivitas}

“Orang belajar lebih baik ketika ia dapat mengendalikan sendiri apa yang sedang dipelajarinya (manipulatif: simulasi, game, branching)." 
Sebenarnya, orang belajar itu tidak selalu linier alias urut satu persatu. Dalam kenyataannya lebih banyak loncat dari satu hal ke hal lain. Oleh karena itu, multimedia pembelajaran harus memungkinkan user/pengguna dapat mengendalikan penggunaan daripada media itu sendiri.dengan kata lain, lebih manipulatif (dalam arti dapat dikendalikan sendiri oleh user) akan lebih baik. Simulasi, branching, game, navigasi yang konsisten dan jelas, bahasa yang komunikatif, dan lain-lain akan memungkinkan tingkat interaktivitas makin tinggi.

\section{Prinsip ke-9: Prinsip Sinyal (clue, highlight)}

"Orang belajar lebih baik ketika kata-kata, diikuti dengan clue, highlight, penekanan yang relevan terhadap apa yang disajikan." Kita bisa memanfaatkan warna, animasi dan lain-lain untuk menunjukkan penekanan, highlight atau pusat perhatian (focus of interest).

\section{Prinsip ke-10: Prinsip Perbedaan Individu}

"9 prinsip tersebut berpengaruh kuat bagi mereka yang memiliki modalitas visual tinggi, kurang berpengaruh bagi yang sebaliknya. Kombinmasi teks dan narasi plus visual berpengaruh kuat bagi mereka yang memiliki modalitas auditori tinggi, kurang berpengaruh bagi yang sebaliknya. Kombinasi teks, visual dan simulasi berpengaruh kuat bagi mereka yang memiliki modalitas kinestetik tinggi, kurang berpengaruh bagi yang sebaliknya." 


\section{Teori-Teori Belajar yang Melandasi Pengembangan Multimedia Berbasis Komputer}

Teori-teori belajar menjelaskan tentang peristiwa yang terjadi selama seseorang belajar. Belajar didefinisikan sebagai proses untuk membentuk tingkah laku. Perubahan yang disadari dan timbul akibat praktek, pengalaman, latihan bukan secara kebetulan. Menurut Ormord (2003:188) dikalangan para ahli terdapat perbedaan pendapat tentang pengertian belajar antara lain "learning is relatively permanent change in behavior due to experience" dan "learning is a relatively permanent change in mental associations due to experience". Kedua pendapat ini memiliki persamaan bahwa perubahan yang terjadi relative permanen dan diakibatkan oleh pengalaman.Pendapat pertama menekankan perubahan tingkah laku, yang lebih dikenal dengan pendapat kaum behavioris.Pendapat kedua menekankan perubahan asosiasi mental, yang lebih dikenal pendapat kaum kognitivis. Namun pada dasarnya belajar selalu melibatkan tiga hal pokok, yaitu: (1) adanya perubahan tingkah laku atau asosiasi mental, (2) perubahan yang relative permanen, (3) perubahan disebabkan karena adanya interaksi dengan lingkungan.

Teori belajar pada dasamya mencari jawaban atau mengkaji pertanyaan mengapa perubahan-perubahan itu terjadi, bukan mengkaji bagaimana.perubahan itu. Terbentuknya tingkah laku sebagai hasil belajar mempunyai tiga ciri pokok yaitu : (a) tingkah laku itu berupa kemampuan aktual dan potensiall; (b) kemampuan itu berlaku dalam waktu yang relatiflama; dan (c) kemampuan baru diperoleh melalui usaha (Nana Sudjana, 1991: 5). 
Munculnya pengembangan multimedia berbasis komputer dalam pembelajaran tidak bisa lepas dari teori belajar dan teori lain yang melandasinya. Teori-teori tersebut memberikan dasar berpijak dalam membangun suatu pola pikir sistematis dalam pembelajaran, sehingga produk-produk pengembangan yang dihasilkan akan dapat teraplikasikan dalam pembelajaran secara optimal.

Menurut Kemp \& Dayton (1985: 13-14), dalam mengembangkan suatu media pembelajaran, sangattepat mendasarkan pada psikologi belajar untuk membantu menempatkan prinsip-prinsip yang mengarahkan pada suatu perencanaan media pernbelajaran yang efektif.Tiga teori belajar yang melandasinya yaitu behavioristik, kognitif dan psikologi sosial. Pendapat ini juga didukung oleh Simonson \& Thomson (1994: 28), yang mengatakan bahwa ada tiga teori yang mendasari penelitian tentang dampak komputer dalam proses pengajaran dan pembe1ajaran, di mana teknik-teknik yang diaplikasikan dalam mendesain dan menggunakan CBI (Computer-based instruction) dapat dilacak dari salah satu teori tersebut. Tiga teori tersebut yaitu teori behaviorisme, teori sistem, dan teori kognitif.Lebih jauh Heinich et al. (1996: 16-18) memberikan pandangannya tentang teori yang melandasi aplikasi pembelalaran baik secara umum maupun secara khusus. Teori-teori tersebut yaitu: 


\section{a. Teor Behavioristik}

Teori behavioristik berpendapat bahwa belajar adalah perubahan tingkah laku sebagai akibat dari adanya interaksi antara stimulus dan respon.. Dalam teori ini yang terpenting adalah masukan (input) yang berupa stimulus, keluaran (output) yang berupa respon, dan penguatan (reinforcement) yang berupa apa saja yang dapat memperkuat timbulnya respon (Asri Budiningsih, 2003: 20).

Dari beberapa teori yang mendukung penggunaan komputer di pendidikan, teori behavioristik secara historis mempunyai kontribusi paling besar. Teori behavioristik digunakan sebagai dasar dalam mendesain awal pembeajaran berbasis komputer dan menjadi pendorong pada banyak strategi pengajaran yang terkait.Seperti penggunaan mesin pengajaran dan teks yang terprogram (Simonson \& Thomson, 1994: 28).

Lebih rincinya, aplikasi teori ini dalam pembelajaran berbasis komputer, diielaskan oleh Simonson \& Thomson (1994: 28-30), bahwa teori behavioristik didasarkan pada prinsip bahwa pembelaiaran seharusnya didesain untuk menghasilkan tingkah laku belajar yang dapat diobservasi dan dikuantitatifkan.Pembelajaran seharusnya ditujukan untuk menghasilkan tingkah laku belajar yang diharapkan. Dengan kata lain, teori behavioristik mengharapkan bahwa aktivitas pembelajaran yang efektif apapun seperti pembelajaran berbasis komputer dapat mengubah sikap siswa dengan cara yang dapat diukur dan dapat dilihat dengan jelas perubahannya. 
Konsep teori bebavioristik yang paling mendasar yaitu penetapan tujuan khusus pembelajaran, harapan bahwa tujuan tersebut dapat mengubah sikap siswa yang dapat diukur, dan materi yang padat seharusnya dipecah menjadi sub-sub materi yang lebih sederhana, seperti dalam pembelajaran berbasis koinputer sebaiknya disusun dari materi yang sederhana ke materi yang lebih komplek.

\section{b. Teori Kognitif}

Teori belajar kognitif mengatakan bahwa belajar tidak sekedar melibatkan hubungan antara stimulus dan respon.Tingkah laku seseorang ditentukan oleh persepsi serta pemahamannya tentang situasi yang berhuhungan dengan.tujuan belajamya. Bagian-bagian dari suatu situasi saling berhubungan dengan seluruh konteks situasi tersebut. Karena belajar merupakan aktifitas yang melihatkan proses berpikir yang sangat kompleks, dalam proses belajar di sini, antara lain mencakup pengaturan stimulus yang diterima dan menyesuaikannya dengan struktur kognitif yang sudah terbentuk di dalam pikiran seseorang berdasarkan pengalaman-pengalaman sebelumnya (Asri Budiningsih, 2003: 34).

Menurut Kemp \& Dayton (1985: 13-14), ciri umum dari teori kognitif tentang proses kognitif yaitu bahwa kcbermaknaan, pemahaman, dan kemampuan mengelola merupakan karakteristik yang mendasar pada tingkah laku manusia. Pembelajaran di sini dipandang sebagai sesuatu yang ditandai dengan suatu kualitas intelegensi dari kemampuan menciptakan suatu hubungan. 
Lebih jauh Simonson \& Thomson (1994: 3637) memberikan gambaran tentang penggunaan teori kognitif sebagai landasan dalam pengembangan multimedia berbasis komputer. Mereka berpendapat bahwa teori kognitif mengutamakan konseptualisasi proses pembelajaran siswa. Teori ini memfokuskan pada eksplorasi cara informasi itu diterima, dikelola, diingat, dan digunakan oleh otak. Pembelajaran berbasis komputer seharusnya disusun dan disampaikan dalam suatu cara yang selalu memberikan pujian pada struktur kognitif dan tingkat pengalaman pebelajar. "Hypermedia \& computer-based instruction" yang "non-linier" dan "non-sequential" merupakan suatu alat yang digunakan oleh para ahli kognitif untuk meneliti bagaimana interaksi siswa dengan pembelajaran selama proses pembelajaran itu sendiri. Dalam pembelajaran berbasis komputer yang "nonlinier" dan "non-sequential", siswa dalam belajamya, tidak harus mengikuti urutan materi yang disajikan. Dia bebas menentukan materi yang dipelajari dan urutannya sendiri, sesuai dengan tingkat kemampuan, kecepatan, dan kebutuhan dalam belajarnya.

\section{c. Teori Konstruktivistik}

Teori konstruktivistik pada dasarnya bukzn teori pembelajaran, tetapi teori tentang pengetahuan dan belajar. Teori konstruktivistik berpendapat bahwa pengetahuan diperoleh sebagai hasil konstruksi kognitif seseorang atas realitas dunianya yang berlangsung terus menerus dan berkesinambungan. Belajar dalam 
prespektif konstruktif dimaknai sebagai proses pemecahan konflik kognitif yang dilakukan secara mandiri, yang nampak melalui pengalaman kongkret, kerja kolaboratif, dan refleksi (Mukminan, 1998: 29).

Menurut Merrill (Anglin, 1995: 119) teori konstruktivistik berpendapat bahwa pengetahuan dikonstruksi oleh pembelajar; pembelajaran merupakan suatu interpretasi pengalaman personal; belajar itu aktif, kolaboratif, dan disituasikan pada konteks dunia nyata; dan penilaian pembelajaran diintegrasikan dalam konteks pembelajaran itu sendiri. Lebih jauh aplikasi teori inii dijelaskan oleh Heinich et al. (1996: 17-18) yaitu bahwa dalam pembelajaran siswalah yang mensituasikan penga1aman belajarnya dengan pengalamannya sendiri dan tujuan pembelajarannya bukan untuk mengajar informasi tetapi menciptakan situasi sehingga siswa menginterpretasikan informasi dalam pemahamannya sendiri.Teori ini juga percaya bahwa pembelajaran berlangsung paling efektif ketika siswa diberikan latihan-latihan yang otentik yang berhubungan dengan konteks-konteks yang bermakna, sehingga ukuran akhir pembelajaran didasarkan pada kemampuan siswa menggunakan pengetahuannya untuk memfasilitasi pemikirannya di dunia nyata.

\section{Kualitas Pembelajaran}

Kualitas dapat dimaknai dengan istilah mutu atau juga keefektifan. Secara definitif, efektivitas dapat dinyatakan sebagai tingkat keberhasilan dalam mencapai tujuan atau sasarannya (Etzioni, 1964). Efektivitas ini sesungguhnya merupakan suatu 
konsepyanglebihluas, mencakup berbagagi faktor didalam ataupun diluar diri seseorang. Dengan demikian, efektivitas ini hanya dapat dari sisi produktivitas, tetapi dapat pula dilihat dari sisi presepsi atau sikap orangnya. Disamping itu, efektivitas juga dapat dilihat dari tingkat kepuasan yang dicapai oleh orang (Robbins, 1997).

Berdasarkan al tersebut, efektivitas merupakan suatu konsep yang sangat penting karena mampu memberikan gambaran mengenai keberhasilan seseorang dalam mencapai sasarannya atau suatu tingkatan terhadap tujuan yang hendak dicapai (Prokopenko, 1987), atau tingkat pencapaian tujuan (Hoy dan Miskel, 1992). Sementara itu, belajar dapat dikatakan sebagai komunikasi terencana yang menghasilkan perubahan atau sikap, keterampilan, dan pengetahuan dalam hubungan dengan sasaran khusus yang berkaitan dengan pola prilaku yang diperlukan individu untuk mewujudkan secara lengkap tugas atau pekerjaan tertentu (Bramley, 1996). Jadi, efektivitas belajar adalah tingkat pencapaian tujuan pembelajaran, termasuk dalam pembelajaran seni. Pencapaian tujuan tersebut berupa peningkatan pengetahuan dan keterampilan serta pengembangan sikap melalui proses pembelajaran.

Dengan pemahaman tersebut, dapat dikemukakan tentang aspek-aspek efektivitas belajar diantaranya sebagai berikut: (1) peningkatan pengetahuan; (2) peningkatan keterampilan; (3) perubahan sikap; (4) perilaku; (5) kemampuan adaptasi; (6) peningkatan integritas; (7) peningkatan partisipasi; dan (8) peningkatan interaksi kultural. Hal ini penting untuk dimaknai bahwa keerhasilan pembelajaran yang dilakukan oleh guru dan siswa ditentukan oleh efektivitasnya dalam upaya pencapaian kompetensi belajar. 
UNESCO (1996) menetapkan empat pilar pendidikan yang harus diperhatikan secara sungguh-sungguh oleh pengelola dunia pendidikan, yaitu:

\section{1) Learning to Know}

Dalam hal ini, pososi seorang guru seyogyanya berfungsi sebagai fasilitator dalam pembelajaran. Disamping itu, guru juga dituntut untuk berperan aktif sebagai teman sejawat dalam berdialog denga siswa dan dalam mengembangkan penguasaan pengetahuan maupun ilmu tertentu.

\section{2) Learning to Do}

Akan bisa berjalan jika sekolah memfasilitasi siswanya untuk mengaktualisasikan keterampilan yang dimilikinya, serta bakat dan minatnya.

Pendeteksian bakat dan minat siswa dapat dilakukan melalui tes bakat dan minat (attitude test). Walaupun bakat dan minat anak bnyak dipengaruhi unsur keturunan (heredity) namun tumbuh berkembangnya bakat dan minat brtgantug pada lingkungannya.

Dewasa ini, keterampilan dapat digunakan untuk menopang kehidupan seseorang bahkan keterampilan lebih dominan dari pada penguasaan pengetahuan dalam mendukung keberhasilan kehidupan seseorang. Untuk itu, pembinaanterhadap keterampilan siswa perlu mendapat perhatian serius.

\section{3) Learning to live Togedher}

Salah satu fungsi lembaga pendidikan adalah tempat bersosialisasi, dan mempersiapkan siswanya untuk dapat 
hidup bermasyarakat. Situasi bermasyarakat hendaknya dikondisikan dilingkungan pendidikan. Kebiasaan hidup bersama, saling menghargai, terbuka, memberi dan menerima, perlu ditumbuhkembangkan dilingkungan sekolah.

\section{4) Learning to Be}

Pengembangan diri secara maksimal erat hubungannya dengan bakat dan miinat, perkembangan fisik dan kejiwaan, tipologi pribadi anak serta kondisi lingkungannya. Bagi anak yang agresif, proses pengembangan dri akan berjalan jika diberi kesempatan cukup luas untuk berkreasi. Sebaliknya, bagi anak yang pasif, peran guru sebagai pengarah sebagagi fasilitator sangat dibutuhkan untuk pengembangan diri siswa secara maksimal. Kemampuan diri yang terbentuk disekolah secara maksimal memungkinkan anak untuk mengembangkan diri pada tingkat yang lebih tinggi. Keempat pilar akan berjalan dengan baik jika diwarnai dengan pengembangan keberagamaan.

Nilai-nilai keberagamaan sangat dibutuhkan bagi setiap warganegara indonesia dalam menapaki kehidupan didunia ini. Penginteegrasian nilai-nilai agama kedalam mata pelajaran yang diajarkan/kepada siswa akan lebih efektif dalam pembentukan pribadi anak yang ber-keuntungan Yang Maha Esa daripada diajarkan secara monolitik yang penuh dengan konsep.

\section{Dampak Multimedia Pembelajaran Interaktif}

Tidak dapat disangkal bahwa terpaan teknologi berupa perangkat lunak (software) ataupun perangkat keras (hardware) 


\section{MEMBANGUN MULTIMEDIA INTERAKTIF}

sudah menyatu dengan kehidupan manusia modern. Dalam bidang pembelajaran, kehadiran media pembelajaran sudah dirasakan banyak membantu tugas guru dalam mencapai tujuan pembelajarannya. Dalam era teknologi dan informasi ini, pemanfaatan kecanggihan teknologi untuk kepentingan pembelajaran sudah bukan merupakan hal yang baru lagi. Salah satu media pembelajaran baru yang akhir-akhir ini semakin menggeserkan peranan guru adalah teknologi multimedia yang tersedia melalui perangkat komputer.

Dengan teknologi ini, kita dapat belajar apa saja, kapan saja, dan dimana saja. Di indonesia, meskipun teknologi ini belum digunakan secara luas, cepat atau lambat teknologi ini akan diserap juga kedalam sistem pembelajaran disekolah. Dalam tulisan ini, akan dikemukakan beberapa persoalan yang muncul sebagai akibat dari diterapkannyanteknologi ini dalam latar pendidikan.

Pertama, berkaitan dengan orientasi filosofi.Ada dua masalah orientasi filosofis yang muncul akibat penerapan teknologi multimedia ini, yakni masalah yang berasal dari pandangan kauum objektivitas menilai desain multimedia sesbagai sesuatu yang sangat nyata dan dapat memebantu pendidikan siswa menggapai tujuan yang diharapkan (Jonassen, 1991). Materi yang berwujud pengetahuan atau keterampilan yang hendak dicapai oleh siswa harus dirancang secara jadi oleh para pengembang intruksional dan dikemas dalam teknologi multimedia ini.

Sebaliknya, kaum kontriktivis berpendapat bahwa pengetahuan hendaklah dibentuk oleh siswa sendiriberdasarkan penafsirannya terhadap pengalaman dan gejala hidup yang 
dialami (Merril, 1991). Belajar adalah suatu interpretasi personal terhadap pengalaman dan kenyataan hidup yang dialami. Berdasarkan pandangan ini maka belajar bersifat aktif, kolaboratif dan terkondisi dalam dalam konteks dunia yang riil.

Kedua, berhubungan dengan lingkungan belajar. Lingkungan belajar multimedia interaktif dapat dikategorikan dalam tiga jenis, yakni lingkungan belajar preskriptif, demokratis, dan sibernetik, (Schwire, 1993). Setiap lingkungan belajar memiliki orientasi dan kekhasan sendiri-sendiri.

Lingkungan preskriptif menekankan bahwa prestasi belajar merupakan pencapaian dari tujuan-tujuan belajar yang ditetapkan secara eksternal. Interaksi belajar terjadi atara siswa dan bahan-bahan belajar yang sudah tersedia dan belajar merupakan sesuatu kegiatan yang bersifat prosedural. Lingkungan belajar demokratis menekankan kontrol proaktif siswa atas belajarnya sndiri, yang mencakup penetapan tujuan belajar sendiri, kontrol siswa terhadap urutan-urutan pembelajaran serta hakikat pengalaman dan kedalaman materi belajar yang dicarinya. Sedangkan lingkungan belajar sibernetik menekankan saling ketergantungan antara sistem belajar dan siswa.

Ketiga, berhubungan dengan desain intruksional. Pada umumnya, desain pembelajaran multimedia dibuat berdasarkan besar kecilnya kontrol siswa atas pembelajarannya. Sebagian besar peneliti mengatakan bahwa siswa dapat diberdayakan melalui kontrol yang lebih besar atas belajarnya, tetapi siswa dapat juga dihambat melalui kontrol atas belajarnya.

Dalam lingkungan yang demokratis dan sibernetik, kegiatan pembelajaran multimedia bervariasi dan tersedia 


\section{MEMBANGUN MULTIMEDIA INTERAKTIF}

untuk untuk siswa pada saat kapan saja dan dalam berbagai bentuk sehingga dapat memuaskan kebutuhan-kebutuhan yang ditetapkan siswa sendiri. Dalam lingkungan belajar preskriptif, kontrol eksternal tampaknya dipaksakan selama tahap awal belajar dan semakin berkurang ketika sudah terlihat kemajuan yang beraarti dalam diri siswa, berupa perubahan perilaku kearah yang diharapkan.

Keempat, berkaitan dengan umpan balik, Sifat dari umpan balik dalam pembelajaran multimedia sangat bervariasi bergantung pada lingkungan dimana multimedia itu digunakan.

Dalam lingkungan belajar preskriptif, umpan balik sering mengambil bentuk koreksi dan deteksi terhadap kesalahan yang dibuat. Dalam lingkungan belajar demokratis, umpan balik sering mengambil bentuk nasehat atau anjurannya, yakni sekedar pemberitahuan kepada siswa tentang akibat-akibat yang muncul dari suatu pilihan tertentu atau juga berisi rekomendisi.

Kelima, sifat sosial dari jenis pembelajaran ini. Banyak kritik telah dilontarkan terhadap pembelajaran multimedia sebagai pembelajaran yang bersifat isolatif sehingga bertentangan dengan dengan tujuan sosial dari sekolah.

Siswa solah-olah dikondisikan untuk menjadi individualis-individualis dan kontak sosial dengan teman-teman menjadi sesuatu yang asing. Itulah beberapa masalah yang perlu diantisipasi jika suatu saat nanti sekolah memutuskan untuk menggunakan teknologi multimedia dalam kegiatan pembelajarannya. Apapun teknologi yang akan dipergunakan hendaknya memperhatikan aspek-aspek tujuan pendidikan yang lebih luas seperti aspek psikologis, sosisal, moral, disamping aspek kognitif-intelektualnya. 
Salah satu usaha yang dikembangkan untuk mengantisipasi sejumlah potensi masalah tersebut maka akhirakhir ini perhatian pendidik mulai diarahkan kepada belajar kooperatif dalam pembelajaran multimedia (Klien \& Pridemore, 1992). Hooper (1992) memperluas pendekatan belajar kooperatif ini dalam ligkungan belajar dan berbasis komputer. Ia mengemukakan beberapa keuntungan dan penerapan belajar kooperatif dalam pembelajaran multimedia, antara lain;

1. Adanya ketergantungan dan tanggung jawab dari setiap anggota kelompok.

2. Adanya interaksi yang promotif dimana usaha seseorang individu akan mendukung usaha anggota kelompok lainnya.

3. Kesempatan latihan untuk bekerja sama.

Proses kelompok yang terjadi didalam lingkungan belajar ini dapat mendorong anggota kelompok untuk merefleksikan efektif atau tidaknya strategi yang digunakan.

\section{Peningkatan Kualitas Pembelajaran dengan Multimedia}

Perbaikan kualitas pendidikan diarahkan pada pada peningkatan kualitas proses pembelajaran, pengadaan buku paket dan buku bacaan atau buku referensi, serta alat-alat pendidikan/ pembelajaran. Peningkatan kualitas proses pembelajaran dilakukan melalui in-service training guru yang sasarannya adalah meningkatkan penguasaan landasan kependidikan, materi pembelajaran (subjact matter), metode dan strategi mengajar, pembuatan dan penggunaan alat pembelajaran, serta evaluasi pembelajaran.

Gurumemgangperanpentingdalamprosespembelajaran. Proses pembelajaran sebagai suatu aktifitas utuk meningkatkan 


\section{MEMBANGUN MULTIMEDIA INTERAKTIF}

pengetahuan, keterampilan, dan sikap siswa berkaitan langsung dengan aktivitas guru, bil disekolah maupun diluar sekolah. Sebagai suatu sistem kegiatan, proses pembelajaran selalu melibatkan guru. Keterlibatan guru tersebut mulai dari pemilihan dan pengurutan materi pembelajaran, penerapan dan penggunaan metode pembelajaran, penyampaian materi pembelajaran, pembimbingan belajar, sampai pada kegiatan pengevaluasian hasil belajar.

Berkaitan dengan peran tersebut, suatu proses pembelajaran akan berlangsung secara baik jika dilaksanakan oleh guru yang memiliki kualitas kompetensi akademik dan profesional yang menadai.

Dan peningkatan mutu guru. Selengkap dan secanggih apapun prasarana dan saran pendidikan, tanpa didukung oleh mutu guru yang baik, hal tersebut tidak memiliki arti yang signifikan terhadap peningkatan mutu pendidikan.

Secara subtantif-teoretis, taraf prestasi atau kualitas pendidikan dikategorikan baik, didasariatas prestasi atau tingkat kecerdasan siswa yang secara umum baik, didasari atas prestasi atau tingkat kecerdasasan siswa yang secara umum baik; siswa akan berprestasi atau cerdas tidak terlepas dari prestasi atau kecerdasan yang dimiliki dosennya (gurunya ketika menimba ilmu LPTK); dosen akan berprestasi stsu cerdas bergantung pada fasilitas atau sarana yang dimiliki institusinya, baik saat mendalami ilmu maupun ketika melaksanakan tugasnya.

Pembelajaran dengan menggunakan multimedia muncul dan berkembang berdasarkan permasalahan yang muncul dalam penerapan teknologi dalam proses pembelajaran dan 
kejenuhan serta kurang komunikatifnya penyampaian materi pembelajaran didalam kelas yang dapat memotivasi belajar peserta didik.

1. Pemanfaatan pembelajaran dengan menggunakan multiedia menjadi suatu solusi dalam peningkatan kualitas pembelajaran yang dilakukan dikelas, dan menjadikan suatu alternatif keterbatasan kesempatan mengajar yang dilaksanakan pendidik.

2. Pembelajaran dengan menggunakan multi media bertujuan untuk memudahkan proses pembelajaran dan menumbuhkan kekreatifan dan ke inofasian pendidik dalam mendisain pembelajaran yang komunikatif dan interaktif serta sebagai jalan permasalahan ditengah kesibukan pendidik.

3. Pengembangan multi media dalam pembelajaran selanjutnya dimanfaatkan kedalam pembelajaran dikelas utntuk menggantikan ataupun sebagai pelengkap dalam pembelajaran konfensional. 



\section{MENGENAL \\ E-LEARNING \\ DENGAN MOODLE}

Dalam bab ini diuraikan mengenai:

[1] Electronic Learning (E-Learning)

[2] Moodle

\section{Electronic Learning (E-Learning)}

Selain sarana untuk menyajikan informasi, komputer dapat dimanfaatkan di berbagai bidang termasuk bidang pendidikan. Pemanfaatan komputer sudah tidak berkembang tidak hanya sebagai alat yang hanya dipergunakan untuk membantu urusan keadministrasian saja, melainkan juga sangat dimungkinkan untuk digunakan sebagai salah satu alternatif dalam pemilihan media pembelajaran, termasuk dalam pembelajaran matematika.Salah satunya yaitu pembelajaran berbasis E- Learning. E-Learning merupakan kependekan dari elektronik learning. E- Learning sering diartikan sebagai proses belajar yang menggunakan komputer atau internet. 


\section{1). Sejarah dan Perkembangan}

E-pembelajaran atau pembelajaran elektronik pertama kali diperkenalkan oleh universitas Illinois di Urbana-Champaign dengan menggunakan sistem instruksi berbasis komputer (computer-assisted instruction ) dan komputer bernama PLATO. Sejak itu, perkembangan E-learning dari masa ke masa adalah sebagai berikut:

a) Tahun 1990 : Era CBT (Computer-Based Training) di mana mulai bermunculan aplikasi e-learning yang berjalan dalam PC standlone ataupun berbentuk kemasan CD-ROM. Isi materi dalam bentuk tulisan maupun multimedia (Video dan Audio) dalam format mov, mpeg-1, atau avi.

b) Tahun 1994 : Seiring dengan diterimanya CBT oleh masyarakat sejak tahun 1994 CBT muncul dalam bentuk paket-paket yang lebih menarik dan diproduksi secara massal.

c) Tahun 1997 : LMS (Learning Management System). Seiring dengan perkembangan teknologi internet, masyarakat di dunia mulai terkoneksi dengan internet. Kebutuhan akan informasi yang dapat diperoleh dengan cepat mulai dirasakan sebagai kebutuhan mutlak, dan jarak serta lokasi bukanlah halangan lagi.

d) Tahun 1999 sebagai tahun Aplikasi E-learning berbasis Web. Perkembangan LMS menuju aplikasi e-learning berbasis Web berkembang secara total, baik untuk pembelajar (learner) maupun administrasi belajar mengajarnya. LMS mulai digabungkan dengan situs- 
situs informasi, majalah, dan surat kabar. Isinya juga semakin kaya dengan perpaduan multimedia, video streaming, serta penampilan interaktif dalam berbagai pilihan format data yang lebih standar, dan berukuran kecil.

\section{2). Pengertian}

Salah satu kosa kata yang muncul dan populer bersamaan dengan hadirnya TIK dalam dunia pembelajaran adalah e-learning.E-learning merupakan kependekan dari elektronik learning.Secara generike-learning berartibelajar dengan menggunakan elektronik. Kata elektronik sendiri mengandung pengertian yang spesifik yakni komputer atau internet, sehinga E- Learning sering diartikan sebagai proses belajar yang menggunakan komputer atau internet.

Sistem pembelajaran elektronik adalah cara baru dalam proses belajar mengajar. E-learning merupakan konsekuensi logis dari teknologi komunikasi dan infortmasi. Dengan e-learning, peserta ajar (learner atau murid) tidak perlu duduk di kelas untuk menyimak setiap ucapa guru secara langsung. E-learning juga dapat mempersingkat jadwal target waktu pembelajaran, dan tentu saja menghemat biaya yang harus dikeluarkan program studi atau program pendidikan.

E-Learning adalah pembelajaran jarak jauh (distance Learning) yang memanfaatkan teknologi komputer, jaringan komputer dan/atau Internet. E-Learning memungkinkan pembelajar untuk belajar melalui komputer di tempat mereka masing-masing tanpa harus secara fisik pergi mengikuti pelajaran/perkuliahan 
di kelas. E-Learning sering pula dipahami sebagai suatu bentuk pembelajaran berbasis web yang bisa diakses dari intranet di jaringan lokal atau internet. Sebenarnya materi e-Learning tidak harus didistribusikan secara on-line baik melalui jaringan lokal maupun internet, distribusisecara off-line menggunakan media CD/DVD pun termasuk pola e-Learning. Dalam hal ini aplikasi dan materi belajar dikembangkan sesuai kebutuhan dan didistribusikan melalui media CD/DVD, selanjutnya pembelajar dapat memanfatkan CD/DVD tersebut dan belajar di tempat di mana dia berada.

E-Learning memungkinkan pembelajar untuk menimba ilmu tanpa harus secara fisik menghadiri kelas. Misalnya, Pembelajar bisa berada di Semarang, sementara "instruktur" dan pelajaran yang diikuti berada di tempat lain, di kota lain bahkan di negara lain. Interaksi bisa dijalankan secara on-line dan real-time ataupun secara offline atau archieved.

Sesungguhnya pengertian elearning sendiri mempunyai makna yang sangat luas dan masih dipersepsikan secara berbeda-beda. Pengertian elearning mencakup sebuah garis kontinum dari mulai menambahkan komputer dalam proses belajar sampai dengan pembelajaran berbasis web. Sebuah kelas yang dilengkapi dengan satu unit komputer untuk memutar sebuah CD pembelajaran interaktif, dalam batasan yang minimal telah dapat disebutkan bahwa kelas tersebut telah menerapkan elearning. Namun menurut batasan UNESCO, elearning paling tidak harus didukung oleh 
sejumlah syarat-syarat yang harus dipenuhi, yaitu mencakup; ketersediaan software bahan belajar berbasis TIK, ketersediaan software aplikasi untuk menjalankan pengelolaan proses pembelajaran tersebut, adanya SDM guru dan tenaga penunjang yang menguasai TIK, adanya infrastruktur TIK, adanya akses internet, adanya dukungan training, riset, dukungan daya listrik, serta dukungan kebijakan pendayagunaan TIK untuk pembelajaran. Apabila elemen-elemen tersebut telah tersedia, maka program dan pengelolaan e-learning akan dapat dijalankan.

Pembelajar belajar dari komputer di kantor ataupun di rumah dengan memanfaatkan koneksi jaringan lokal ataupun jaringan Internet ataupun menggunakan media CD/DVD yang telah disiapkan. Materi belajar dikelola oleh sebuah pusat penyedia materi di kampus/universitas, atau perusahaan penyedia content tertentu. Pembelajar bisa mengatur sendiri waktu belajar, dan tempat dari mana ia mengakses pelajaran.

E-Learning disampaikan dengan memanfaatkan perangkat komputer.Pada umumnya perangkat dilengkapi perangkat multimedia, dengan cd drive dan koneksi Internet ataupun Intranet lokal.Dengan memiliki komputer yang terkoneksi dengan intranet ataupun Internet, pembelajar dapat berpartisipasi dalam e-Learning.Jumlah pembelajar yang bisa ikut berpartisipasi tidak dibatasi dengan kapasitas kelas.Materi pelajaran dapat diketengahkan dengan kualitas yang lebih standar dibandingkan kelas konvensional yang tergantung pada kondisi dari pengajar.

E-Learning bisa mencakup pembelajaran secara 
formal maupun informal.E-Learning secara formal, misalnya adalah pembelajaran dengan kurikulum, silabus, mata pelajaran dan tes yang telah diatur dan disusun berdasarkan jadwal yang telah disepakati pihak-pihak terkait (pengelola e-Learning dan pembelajar sendiri).Pembelajaran seperti ini biasanya tingkat interaksinya tinggi dan diwajibkan oleh perusahaan pada karyawannya, atau pembelajaran jarak jauh yang dikelola oleh universitas dan perusahaanperusahaan (biasanya perusahan konsultan) yang memang bergerak di bidang penyediaan jasa e-Learning untuk umum. E-Learning bisa juga dilakukan secara informal dengan interaksi yang lebih sederhana, misalnya melalui sarana mailing list, e-newsletter atau website pribadi, organisasi dan perusahaan yang ingin mensosialisasikan jasa, program, pengetahuan atau keterampilan tertentu pada masyarakat luas (biasanya tanpa memungut biaya).

Walaupun sepertinya e-Learning diberikan hanya melalui perangkat komputer, e-Learning ternyata disiapkan, ditunjang, dikelola oleh tim yang terdiri dari para ahli di bidang masing-masing, yaitu:

1) Subject Matter Expert (SME) atau nara sumber dari pelatihan yang disampaikan.

2) Instructional Designer (ID), bertugas untuk secara sistematis mendesain materi dari SME menjadi materi e-Learning dengan memasukkan unsur metode pengajaran agar materi menjadi lebih interaktif, lebih mudah dan lebih menarik untuk dipelajari.

3) Graphic Designer (GD), mengubah materi text menjadi bentuk grafis dengan gambar, warna, dan 
layout yang enak dipandang, efektif dan menarik untuk dipelajari.

4) Ahli bidang Learning Management System (LMS). Mengelola sistem di website yang mengatur lalu lintas interaksi antara instruktur dengan siswa, antarsiswa dengan siswa lainnya.

Di sini, pembelajar bisa melihat modul-modul yang ditawarkan, bisa mengambil tugas-tugas dan testtest yang harus dikerjakan, serta melihat jadwal diskusi secara maya dengan instruktur, nara sumber lain, dan pembelajar lain. Melalui LMS ini, siswa juga bisa melihat nilai tugas dan test serta peringkatnya berdasarkan nilai (tugas ataupun test) yang diperoleh.

E-Learning tidak diberikan semata-mata oleh mesin, tetapi seperti juga pembelajaran secara konvensional di kelas, e-Learning ditunjang oleh para ahli di berbagai bidang terkait.

\section{3). Kekurangan dan Kelebihan}

Seperti Sebagaimana yang disebutkan di atas, e-learning telah mempersingkat waktu pembelajaran dan membuat biaya studi lebih ekonomis.E-learning mempermudah interaksi antara peserta didik dengan bahan/materi, peserta didik dengan dosen/guru/ instruktur maupun sesama peserta didik.Peserta didik dapat saling berbagi informasi dan dapat mengakses bahan-bahan belajar setiap saat dan berulang-ulang, dengan kondisi yang demikian itu peserta didik dapat lebih memantapkan penguasaannya terhadap materi pembelajaran. 
Dalam e-learning, faktor kehadiran guru atau pengajar otomatis menjadi berkurang atau bahkan tidak ada.Hal ini disebabkan karena yang mengambil peran utama adalah computer yang dirancang oleh "contents writer", designer program komputer.

Dengan adanya e-learning para guru/dosen/ instruktur akan lebih mudah :

1) Melakukan pemutakhiran bahan-bahan belajar yang menjadi tanggung jawabnya sesuai dengan tuntutan perkembangan keilmuan yang mutakhir

2) Mengembangkan diri atau melakukan penelitian guna meningkatkan wawasannya

3) Mengontrol kegiatan belajar peserta didik.

Kehadiran guru sebagai makhluk yang hidup yang dapat berinteraksi secara langsung dengan para murid telah menghilang dari ruang-ruang elektronik e-learning ini.Inilah yang menjadi ciri khas dari kekurangan e-learning yang tidak bagus.Sebagaimana asalearning yang terdiri dari e (elektronik) dan learning (belajar), maka sistem ini mempunyai kelebihan dan kekurangan.

Banyak perangkat bergerak saat ini telah mendukung penggunaan audio. Beberapa tipe file yang biasanya digunakan di lingkungan divais bergerak antara lain rm, mp3, amr dan lain-lain. Oleh karena file audio biasanya memiliki ukuran yang cukup besar, menyebabkan file audio tersebut harus diolah terlebih dahulu sehingga dapat digunakan di lingkungan divais bergerak yang memiliki kapasitas memori yang relatif kecil. 
1. Video

Meski dalam kualitas dan ukuran yang terbatas, beberapa tipe divais bergerak telah mampu memainkan file video. Format file yang didukung oleh divais bergerak antara lain adalah 3gp, MPEG, MP4, dan lain-lain. Sama seperti file audio, kebanyakan file video memiliki ukuran yang cukup besar sehingga harus dikonversi dan disesuaikan dengan keterbatasan divais.

2. Aplikasi Perangkat Lunak

Konten yang cukup menarik adalah aplikasi perangkat lunak yang dipasang pada divais. Perangkat lunak dapat dikostumisasi sesuai kebutuhan sehingga akan lebih mudah dan intuitif untuk digunakan. Aplikasi perangkat lunak ini juga mampu menggabungkan konten-konten lain seperti teks, audio dan video sehingga menjadi lebih interaktif. Jenis aplikasi yang saat ini banyak digunakan antara lain aplikasi berbasis WAP/WML, aplikasi Java, aplikasi Symbian, dan lain-lain.

\section{Moodle}

MOODLE (singkatan dari Modular Object-Oriented Dynamic Learning Management) adalah paket perangakat lunak yang diproduksi untuk kegiatan belajar berbasis internet dan situs web yang menggunakan prinsip social contructionis pedagogy. Moodle merupakan salah satu aplikasi dari konsep dan mekanisme belajar mengajar yang memanfaatkan teknologi informasi, yang dikenal dengan konsep pembelajaran elektronik atau e-learning. Moodle dapat digunakan secara bebas sebagai produk sumber terbuka (open source) dibawah lisensi GNU. 


\section{MEMBANGUN MULTIMEDIA INTERAKTIF}

Moodle dapat diinstal di computer dan system operasi apapun yang bisa menjalankan PHP dan mendukung database SQL.

Martin Doegiamas, yang telah lulus pada ilmu computer dan pendidikan, menulis versi pertama Moodle. Dougiamas memulai Ph.D untuk menguji "kegunaan software open-source untuk mendukung epistimologi pengajaran dan pembelajran menggunakan komunitas berbasis internet." Pendekatan Moodle secara filsafat termasuk kontruktivitas dan kontruksi sosial ialah untuk pendidikan, menekankan pembelajat (dan tidak hanya guru) dapat berkontribusi pada pengalaman edukasional. Menggunakan prisip pedaogikal, Moodle menyediakan lingkungan fleksibel untuk komunitas belajar.

Di dunia e-learning Indonesia, Moodle lebih dikenal fungsinya sebagi Course Management System (CMS) atau Learning Management System (LMS). Dengan tampilan seperti halaman web pada umumnya, Moodle juga memiliki fitur untuk menyajikan kursus (course), dimana pengajar bisa menunggah materi ajar, soal dan tugas. Murid bisa masuk log ke Moodle kemudian memilih kursus yang disediakan atau di-enroll untuknya. Aktivitas murid di dalam Moodle ini akan terpantau progress nilainya. Di Indonesia sendiri, diketahui bahwa Moodle telah dimanfaatkan untuk sekolah menegah, perguruan tinggi dan perusahaan.

Sebagai LMS, Moodle memiliki fitur yang tipikal dimiliki LMS pada umumnya ditambah beberapa fitur unggulan. Fitur tersebut adalah : Assignment submission, Forum Diskusi, Unduh Arsip, Peringkat, Chat, Kalender Online, Berita, Kuis Online, Wiki dan fitur lainnya. Developer dapat meningkatkan kontruksi modular Moodle dengan menciptakan plugin untuk fungsi-fungsi baru yang lebih spesifik. Infrastruktur Moodle mendukung banyak tipe plugin seperti : aktifitas, jenis sumber daya, 
jenis pertanyaan, jenis pengisian data, tema bergambar, metode auhentifikasi, metode pengambilan pembelajaran, penyaring konten. (Sumber: https://id.wikipedia.org/wiki/Moodle). Berikut ini adalah contoh tampilan e-learning hasil karya mahasiswa pendidikan matematika UAD dengan menggunakan moodle.

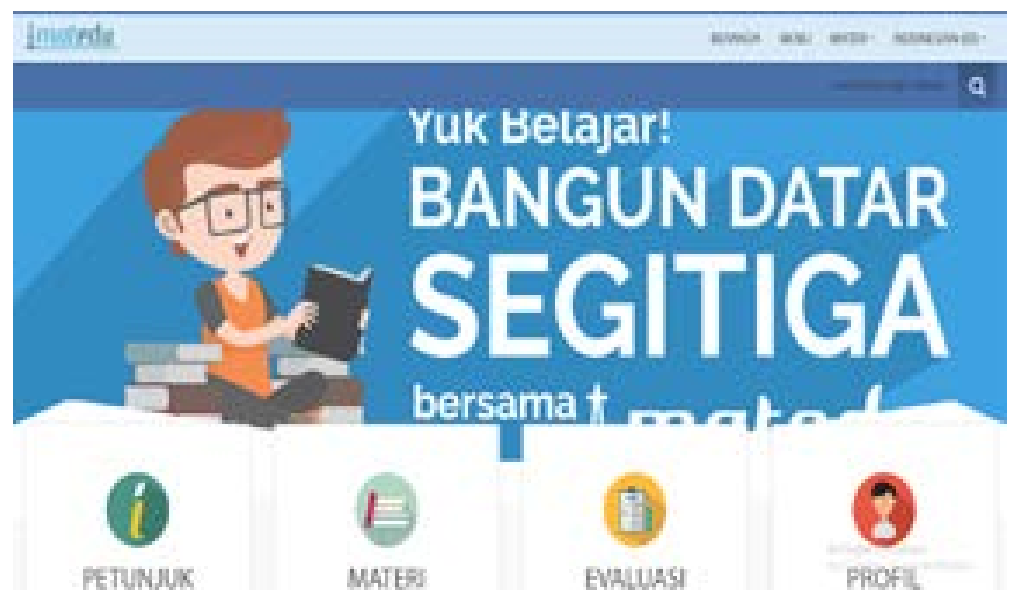

Sumber: https://matedu.gnomio.com/

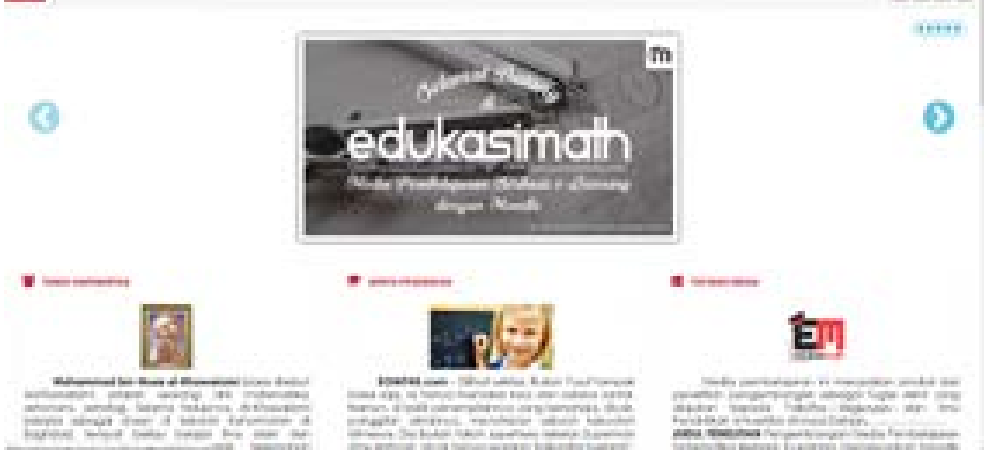

Sumber: https://edukasimath.gnomio.com/ 


\section{a) Membangun Website Pembelajaran Dengan Moodle}

Moodle merupakan aplikasi gratis yang sangat mudah untuk dioperasikan. Bermodalkan computer dan jaringan internet Moodle bisa diakses dan dioperasikan kapan saja. Seperti halnya membuat blog, Moodle hadir untuk membantu para pendidik dalam pembelajaran. Berikut ini langkah-langkah untuk membuat website pembelajaran menggunakan Moodle. Hal-hal yang harus dipersiapkan terlebih dahulu, yaitu :

1. Komputer atau Laptop

2. Jaringan internet

3. E-mail yang masih aktif (gmail lebih mudah untuk penggunaan)

\section{Langkah-langkah mendaftarkan website Moodle adalah sebagai berikut :}

1. Silahkan akses alamat https://www.gnomio.com;

2. Pada "Create your site" terdapat kolom "Name" dan "E-mail”;

3. Kolom "Name" adalah nama website yang akan dibuat, nama website akan terdaftar hanya sekali dan tidak boleh sama dengan nama website yang telah terdaftar sebelumnya, serta maksimal 2-32 karakter;

4. Kolom "E-mail" adalah memasukkan e-mail yang masih aktif bertujuan untuk mengirimkan user dan password admin (pemilik website);

5. Pada latihan ini kami mencoba mengisikan Name : yc dan E-mail : xxx@gmail.com;

6. Setelah diisikan semua maka klik tombol "Create" yang berada di sebelah kanan kolom e-mail; 
7. Setelah klik "Create" akan muncul tulisan "Your site is being created. Within a few minutes you will receive an email with login info. If you do not receive it please check your SPAM folder. Thank you!". Artinya adalah data user dan password akan dikirim ke email yang sudah dimasukan, jika tidak ada di menu inbox diminta cek di menu spam;

8. Setelah cek email masuk maka diminta untuk membuka web moodle yang telah dibuat. Sebagai contoh kami mengakses https://yc.gnomio.com seperti pada poin 5 mendaftarkan nama website dengan yc;

9. Setelah terbuka, klik menu log in di pojok kanan atas, Kemudian, masukkan user dan password sesuai yang dikirim via email;

10. Website yang Anda buat sekarang sudah bisa dioperasikan.

\section{b) Membuat Courses Dan Kategori Pada Moodle}

Apabila website sudah terbuat maka pertama kali yang harus dilakukan adalah membuat courses (kursus). Pada kursus ini dibagi menjadi dua bagian, yaitu kategori dan courses itu sendiri. Kategori adalah judul utama pembahasan, Courses adalah Bab dan isi dari kursus adalah sub bab. Misalnya Kategori adalah Bangun Ruang Sisi Datar, salah satu Kursusnya adalah Kubus dan isi dari kursus adalah Pengertian Kubus, Luas dan Volume Kubus, dsb.

A. Berikut ini adalah langkah-langkah membuat Kategori.

1. Silahkan buka website moodle yang telah Anda buat.

2. Log in sebagai administrator. 
3. Klik "Site Administrator" yang berada di sebelah kiri nama website. Jika tidak muncul klik gambar 3 garis di pojok kiri atas.

4. Setelah itu klik menu tab "Courses".

5. Kemudian klik "Manage courses and categories".

6. Klik “Create new category”, maka akan muncul tampilan "Add new category" dan beberapa menu di bawah ini :

a. Parent Category : pilih “Top" saja, artinya jika memilih Top maka kategori yang dibuat berdiri sendiri bukan menjadi sub kategori yang ada.

b. Category Name : adalah nama kategori yang akan dibuat. Isi sesuai dengan kebutuhan, sebagai Contoh : Bangun Ruang Sisi Datar

c. Categori ID Number : tidak wajib untuk diisi

d. Descripton : Tidak wajib untuk diisi

7. Setelah semua selesai klik "Create Category", maka kategori yang dibuat ada di bawah kategori Miscellaneous.

8. Kategori baru sudah terbuat. Selanjutnya adalah membuat Kursus.

B. Berikut ini langkah-langkah membuat Kursus.

1. Silahkan buka website moodle yang telah Anda buat.

2. Log in sebagai administrator

3. Klik "Site Administrator" yang berada di sebelah kiri nama website. Jika tidak muncul klik gambar 3 garis di pojok kiri atas. 
4. Setelah itu klik menu tab "Courses".

5. Kemudian klik "Manage courses and categories".

6. Pilih kategori yang akan ditambahkan kursus. Sebagai contoh : Saya klik kategori Bangun Ruang Sisi Datar (mengacu pada contoh membuat kategori).

7. Maka setelah di klik di samping kanan menu kategori akan muncul nama kategori yang ingin ditambahkan kursus.

8. Selanjutnya klik "Create new course", maka akan muncul tampilan "Add new course" dan beberapa menu sebagai berikut :

\section{a. General}

- Course full name : memberikan nama Course secara lengkap misalnya Kubus

- Course short name : memberikan nama singkatan pada course, biar lebih enak maka tetap ditulis Kubus

- Course Category : Kursus masuk kategori yang telah dibuat

- Course visibility : biarkan terlihat ("Show")

- Course start date : kursus akan muncul pada hari yang ditentukan

- Course end date : kursus akan diakhiri pada hari yang ditentukan (lebih baik dimatikan dengan cara hilangkan centang pada "enable"

- Course ID number : tidak wajib diisi

b. Description : tidak wajib diisi

c. Course Format 
- Format : topic format

- Number of section : 0

- Hidden Section : tidak dirubah

- Course layout : tidak dirubah

d. Apperance : tidak dirubah

e. File and Uploads : tidak dirubah

f. Groups : tidak dirubah

g. Role Renaming : tidak dirubah

h. Tags : tidak dirubah

9. Selanjutnya "Save and Return".

\section{Membuat Aktivitas dari Kursus}

1. Silahkan buka website moodle yang telah Anda buat.

2. Log in sebagai administrator.

3. Klik "Site Administrator" yang berada di sebelah kiri nama website. Jika tidak muncul klik gambar 3 garis di pojok kiri atas.

4. Setelah itu klik menu tab "Courses".

5. Kemudian klik "Manage courses and categories".

6. Pilih kategori yang diinginkan, di sini dicontohkan kategori "Bangun Ruang Sisi Datar"

7. Pada sisi kanan setelah memilih kategori akan muncul sub dari kategori yang disebut kursus. Pilih yang ingin diberikan aktivitas, di sini dicontohkan kursus "Kubus".

8. Arahkan ke bawah (scroll ke bawah), pilih menu "View"

9. Setelah proses loading selesai Klik menu gambar "Gerigi" di samping kanan 
10. Klik "Turn Editing On"

11. Jika di bawah tulisan "Announcements" ada menumenu "Topic" maka bisa dilakukan penyembunyian Topic. Yaitu dengan cara klik "Edit" $\rightarrow$ "Hide Topic"

12. Untuk menambakan aktifitas materi maka klik "Add an activity or resource"

13. Setelah di klikakan muncul kotak dialog, pilih "Page" $\rightarrow$ "Add"

14. Muncul halaman "Add a new Page". Pada halaman ini ada beberapa menu yang harus diisi, diantaranya adalah sebagai berikut :

\section{a. General}

- Name : adalah nama aktivitas materi yang akan dibuat. Misalnya : Pengertian Kubus (wajib diisi)

- Description : Tidak wajib diisi

\section{b. Content}

- Page Content : isi dari materi yang akan disampaikan

15. Biarkan menu-menu yang lain diatur sesuai dengan format asli tidak perlu dirubah.

16. Klik "Save and Return to course"

17. Maka aktivitas pembelajaran sudah terbuat. Untuk menambahkan tinggal mengulangi langkah-langkah sebelumnya. 


\section{c) Embed Media Geogebra Dan Youtube Ke Dalam Moodle}

\section{A. Embed Youtube ke dalam Moodle}

Langkah-langkah mengembef Youtube ke dalam Moodle

1. Buka website moodle yang sudah dibuat

2. Log in sebagai administration

3. Langkah seperti membuat aktivitas materi pada bab III bagian $\mathrm{C}$.

4. Akan tetapi yang membuat beda adalah pada pengisian konten saja. Di sini kami menganggap bahwa membuat page (aktivitas materi) peserta sudah paham. Jika belum paham silahkan ulangi langkah untuk membuat aktivitas materi.

5. Pada page content ada gambar keyboard menu pertama kotak kecil, silahkan klik maka akan menampilkan banyak sekali pilihan.

6. Pilih menu yang gambarnya “< > atau html. Untuk mengisi konten terlebih dulu buka video youtube yang akan diembed.

7. Setelah video terbuka klik menu share di bawah video sebelah kanan.

8. Muncul kotak dialog pilih "Embed"

9. Copy kode html dari <iframe ......... > sampai dengan </ iframe>.

10. Kemudian paste di page content yang sudah dirubah ke versi html. Jika belum dirubah ke versi html lakukan langkah 4 sampai dengan 6.

11. Atur ukuran video dengan mengubah "width dan height" pada kode scriptmya. 


\section{B. Embed Geogebra ke dalam Moodle}

1. Buka website moodle yang sudah dibuat

2. Log in sebagai administration

3. Langkah seperti membuat aktivitas materi pada bab III bagian $\mathrm{C}$.

4. Akan tetapi yang membuat beda adalah pada pengisian konten saja. Di sini kami menganggap bahwa membuat page (aktivitas materi) peserta sudah paham. Jika belum paham silahkan ulangi langkah untuk membuat aktivitas materi.

5. Pada page content ada gambar keyboard menu pertama kotak kecil, silahkan klik maka akan menampilkan banyak sekali pilihan.

6. Pilih menu yang gambarnya " $<>$ " atau html. Untuk mengisi konten terlebih dulu buka video youtube yang akan diembed.

7. Buka alamat www.geogebra.org

8. Login terlebih dahulu ke geogebra. Bisa dengan menggunakan gmail yang sudah ada

9. Setelah login cari materi yang akan digunakan di menu "search materials"

10. Ketika sudah muncul akan ada banyak pilihan yang terdapat pada geogebra.

11. Klik pada 3 kotak kecil. Kemudian klik share.

12. Akan ada menu pilihan "group", "Link", "Email", dan "Embed".

13. Klik menu "Embed". Setelah klik embed lakukan langkah 
yang sama seperti memasukkan kode embed dari youtube ke geogebra mulai dari langkah 9 sampai dengan 11 .

\section{d) Membuat Bank Soal Dan Kategori Soal}

\section{A. Membuat Kategori Soal}

Langkah-langkah menbuat kategori soal pada moodle adalah sebagai berikut.

1. Buka website moodle yang sudah dibuat

2. Log in sebagai administration

3. Pada "Home" atau tampilan awal moodle setelah login ada gambar gerigi di pojok kanan.

4. Klik gambar "Gerigi" $\rightarrow$ "More"

5. Pada menu "Front page setting" klik "Question bank"

6. Ada beberapa menu pilihan sebagai berikut :

a. Question : daftar soal atau kumpulan soal dan pertanyaan

b. Categories : daftar kategori soal

c. Import : memasukkan soal secara masal

d. Export : Mendownload soal yang sudah dibuat

7. Dari beberapa menu a - d untuk membuat kategori pilih "Categories"

8. Pada bagian "Add category" ada beberapa pilihan menu, yaitu :

a. Parent category : kelompok kategori. Disini memilih "system top" pada menu parent category

b. Name : Nama kategori, misalnya "soal bangun ruang"

c. Category info : info dari kategori. Tidak wajib diisi 

9. Klik "Add category"
10. Kategori telah terbuat.

B. Membuat Kumpulan Soal dan Memasukkan ke Dalam Kategori

Langkah-langkah menbuat kategori soal pada moodle adalah sebagai berikut.

1. Buka website moodle yang sudah dibuat

2. Log in sebagai administration

3. Pada "Home" atau tampilan awal moodle setelah login ada gambar gerigi di pojok kanan.

4. Klik gambar "Gerigi" $\rightarrow$ "More"

5. Pada menu "Front page setting" klik "Question bank"

6. Ada beberapa menu pilihan sebagai berikut :

a. Question : daftar soal atau kumpulan soal dan pertanyaan

b. Categories : daftar kategori soal

c. Import : memasukkan soal secara masal

d. Export : Mendownload soal yang sudah dibuat

7. Dari beberapa menu a-d untuk membuat kategori pilih "Question"

8. Untuk memasukkan soal ke dalam kategori maka pada menu "select a category" pilih kategori yang sudah dibuat misalnya "soal bangun ruang" karena mengacu pada langkah sebelumnya.

9. Kemudian Klik "create a new question" 
10. Akan banyak sekali pilihan menu question. Pilih "Multiple choice" untuk pilihan ganda Klik "Add"

11. Muncul menu "Adding a Multiple choice question" dan ada beberapa sub menu seperti :

a. General

- Category : pilih mau ditempatkan di kategori mana soal yang akan dibuat

- Question name : nama dari pertanyaan. Misalnya "SOAL"

- Question text : adalah soal yang akan diujikan

- Default mark : biarkan "1" saja. Maksudnya hanya memilih 1 pilihan

- On or multiple answers? : pilih "one answer only"

- Number the choices? : tipe dari pilhan ganda

b. Answers

- Choice 1 : artinya pilihan a

- Grade : jika benar pilih “100\%” jika salah pilih "None"

- Feedback : umpan balik yang diberikan ke siswa

c. Combined feddback

d. Multiple tries

e. Tags

12. Pada point $\mathrm{c}$ - e tidak perlu dirubah. Biarkan sesuai dengan pengaturan awal.

13. Pilih "Save changes" 


\section{e) Membuat Kuis}

Langkah-langkah membuat kuis sebagai berikut.

1. Lakukan langkah yang sama seperti BAB III point C.

2. Lakukan sampai dengan point 12 .

3. Setelah itu pilih "Add an activity or resource" $\rightarrow$ "Quiz" $\rightarrow$ "Add"

4. Pada menu "Adding a new Quiz" karena terlalu banyak pengaturan yang ada maka lebih baik fokus terhadap "General".

5. Isi pada menu "Name". Isikan nama quiz yang akan dibuat misalnya "EVALUASI"

6. Pilih "Save and Display"

7. Kemudian pilih "Edit quiz"

8. Di bawah keterangan "Shuffle" klik "Add" $\rightarrow$ "+ from question bank"

9. Pilih "Select a category"

10. Pilih kategori di mana tadi sudah dibuat kategori "Bangun ruang sisi datar"

11. Centang semua soal yang sudah dibuat.

12. Pilih "Add"

f) Membuat Dan Memasukkan User Kedalam Pembelajaran

\section{A. Membuat User Secara Masal}

Membuat user secara masal adalah membuat user dengan cara mengunggah user lebih dari satu sekali membuat user. Dalam hal ini harus ada bantuan menggunakah Ms. Excel. Langkah-langkahnya adalah sebagai berikut. 
1. Buka terlebih Ms. Excel pada computer Anda.

2. Buatlah format seperti di bawah ini.

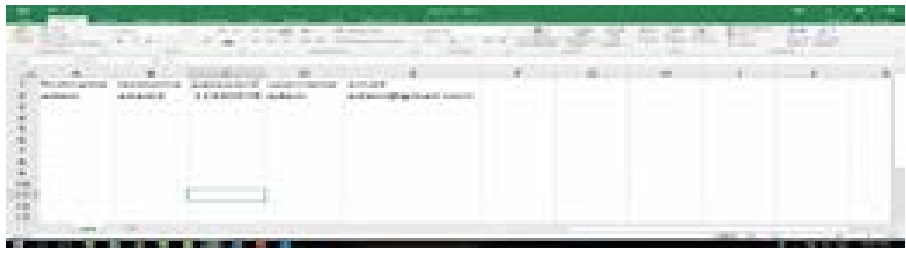

3. Buatlah user sesuai jumlah yang diinginkan.

4. Jika sekiranya sudah selesai Pilih "File" $\rightarrow$ "Save as" $\rightarrow$ pilih folder di mana file akan disimpan.

5. Ada perbedaan dalam penyimpanan yaitu pada "Save as Type" di bawah file name dirubah ke dalam bentuk .CSV (comma delimited)

6. Klik "Save". Maka kita sudah mempunyai master user yang akan kita upload masal.

7. Buka web Moodle yang sudah dibuat.

8. Log in sebagai administrator.

9. Klik "Site administration" $\rightarrow$ pilih menu "Users"

10. Pada menu "Account" pilih "Upload Users"

11. Akan muncul halaman "Upload users" dan ada beberapa sub menu sebagai berikut.

a. File : file yang akan diunggah. Klik "Choose a file" $\rightarrow$ "Upload a file" $\rightarrow$ "Choose File" atau "Browser" $\rightarrow$ "Pilih file user yang dibuat sebelumnya" "Open" $\rightarrow$ "Upload this file"

b. CSV delimiter : jika menggunakan office 2013 ke atas maka dipilih "," untuk formatnya. Akan tetapi 
untuk office 2013 ke bawah bisa menggunakan ";" untuk formatnya.

C. Encoding : tidak perlu dirubah.

d. Preview rows : tidak perlu dirubah.

12. Klik "Upload users"

13. Setelah itu akan muncul halaman "Upload users preview", artinya users yang telah dibuat berhasil di upload.

14. Scroll ke bawah tanpa harus mengubah pengaturan.

15. Klik "Upload users" $\rightarrow$ "Continue"

16. Akan kembali ke halaman "Upload users" artinya file sudah terupload. Sehinga users siap dimasukkan ke dalam pembelajaran.

\section{B. Memasukkan User ke Dalam Pembelajaran}

1. Buka web Moodle yang sudah dibuat.

2. Log in sebagai administrator.

3. Klik "Site administrator"

4. Pilih menu "Courses"

5. Kemudian klik "Manage courses dan categories"

6. Pada "Course categories" pilih materiyang akan dibuka untuk siswa. Misalnya adalah "Bangun Ruang Sisi Datar" (karena sudah dibuat pada BAB sebelumnya)

7. Setelah itu lihat di samping kanan yaitu "Bangun Ruang Sisi Datar" akan ada materi yang telah kita buat misalnya saja klik "KUBUS"

8. Scroll ke bawah pilih "Enrolled users" 
9. Maka akan ada dua pilihan enroll users. Pilih yang bawah untuk "enrol users"

10. Muncul kotak dialog yang akan menampilkan users yang sudah kita buat. Tinggal klik "enrol"

11. Apabila sudah cukup klik "Finish enrolling users".

12. Memasukkan siswa ke dalam pembelajaran maka sudah selesai. 


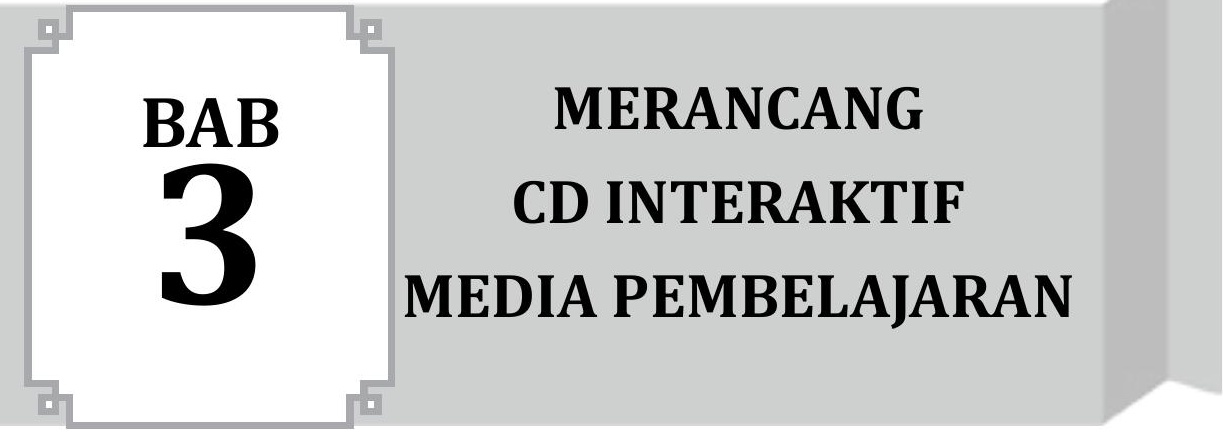

Dalam bab ini diuraikan mengenai:

[1] Perencanaan

[2] Penyusunan Konsep Media

[3] Rancangan Konsep dalam Bentuk Dokumen Naratif

[4] Penyusunan Desain atau Rancangan

[5] Pembuatan Diagram Alir

[6] Manajemen Directory

\section{Perencanaan}

Sebelum anda membuat CD interaktif media pembelajaran, terlebih dahulu anda harus melakukan perencanaan atau desain terlebih dahulu dalam bentuk draft. Hal ini perlu di lakukan terlebih sehingga pada saat anda mengembangkan media pembelajaran, maka semua hasil akhir akan sesuai dengan rancangan awal.

Langkah-langkah perencaan yang harus anda lakukan meliputi : penyusunan konsep dan desain, membuat diagram alir, manajemen direktorit dan pengumpulan bahan. Semua langkah akan dijelaskan secara bertahap dallam bab ini dan akan di sajikan dalam bentuk contoh terapan. 


\section{Penyusunan Konsep Media}

Sebelum membuat CD interaktif tentunya anda harus menetapkan tujuan yang akan di capai dari media yang akan di buat. Setelah menetukan tujuan, anda harus menentukan sasaran, siapa audiens pengguna media anda. Yang terakhir, anda harus memikirkan dalam bentukk aplikasi apa media akan di buat.

Untuk memulai tahapan penyusuanan konsep ini dibuat dalam bentuk dokumen teks dengan penulisan yang bersifat naratif untuk mengungkapkan tujuan proyek pengembangan media. Di bawah ini adalah salah satu contoh rancangankonsep naratif sederhana yang menjabarka semua konsep program pembelajaran melalui media. Anda dapat mengembangkan contoh-contoh lain yang anda uat sendiri sehingga menjadi pedoman dasar dalam pengembangan media, maka tahapan berikut selalu bertiik tolak dari konsep yang sudah dirancang sebelumnya.

\section{Rancangan Konsep dalam Bentuk Dokumen Naratif}

CD interaktif media pembelajran disusun untuk mata pelajaran matematika, meliputi pokok bahasan tentang geometri dan subpokok bhasan bangun-bangun data dan akan dibatasi pada pembahasan sifat-sifat segitiga saja.

Fasilitas dan konten yang akan dikembangkan dalam bentuk CD interaktif, antara lain :

1. Media memunyai halaman antar muka utamadiantranya halaman login, halaman ini berfungsi untuk login bagi pengguna media. From pada halaman ini adalah form untuk nama pengguna dan password.

2. Halaman selamat datang, halaman ini berisi ucapan selamat datang datang bagi pengguna media. Halaman 
selamat datang akan terbuka, jika pengguna media berhasil masuk ke halaman login. Halaman selamat datang dilengkapi dengan tombol Lanjut atau tombol Enter, yaitu tombol navigasi untuk menuju halaman utama.

3. Halaman utama, halaman ini mempunya fasilitas-fasilitas :

1) Petunjuk, fasilitas ini berisi petunjuk atau informasi bagaimana menggunkan media pembelajran, untuk dapat membuka fasilitas ini di buat tombol navigasi dengaan nama tombol "Petunjuk".

2) Pendahuluan, fasilitas ini berisi informasi-informasi seputar isi materi yang akan di pelajari oleh peserta didi, informasi yang menyertai pada fasilitas ini diantranya tentang standar kompetensi, standar kompetensi dasar dan indikator ketercapaian materi. Untuk dapat membuka fasilitas ini di buat tombol navigasi dengan nama tombol "Pendahuluan".

3) Materi, fasilitas ini berisi uraian materi pembelajaran, semua materi yang digunakan didasarkan pada kurikulum yang berlaku utnuk SMP Kelas VIII. Materi pembelajaran disajikan dengan menggambungkan teks, audio, animasi, dan video. Uratan sajian materi dilampirkan pada dokumen ini.

4) Latihan, untuk memberikan umpan balik dari proses pembelajarn melalui media pembelajarn ini, dibuatkan fasiltas latihan, latihan dalam bentuk soal pilihan gandaa sebnyak 10 soal, sistem penilaian ini adalah jika jawaban ini salah nilai nol dan jawaban benar bernilai 1 , fasilitas ini dilengkapi dengan hasil 
berupa nilai dari soal-soal yang telah dikerjakan oleh peserta didik. Untuk dapat menggunakan fasilitas ini digunakan tombol navigasi yang diberi nama tombol "Latihan".

5) Evaluasi, fasilitas ini berisi informasi tentang data diri penyusun media, untuk dapat menggukan fasilitas ini dilengkapi dengan tombol navigasi dan diberi nama "Talent".

\section{Penyusunan Desain atau Rancangan}

Setelah tahapan konseptual selesai ditentukan, maka langkah selanjutnya adalah mentukan spesifikasi secara terperinci mengenai arsitektur media, gaya, dan kebutuhan material untuk pembuatan media.

Speifikasi hendaknya dibuat secra rinci sehingga pada tahapan berikutnya yaitu pada saat melakukan pengumpulan materi dan pemasangan materi, anda tidak perlu memerlukan keputusan baru tetapi menggunakan apa yang sudah di tentukan pada tahap desain.

Dalam tahapan ini, anda di tuntut untuk mengeluarkan semua kemampuan dan ide dalam pembuatan story board. Dengan demikian, maka anda dapat menunjukan imajinasi dalam sebuah adegan dari alur cerita yang akan anda susun.

Idealnya, tory board yang anda susun harus dapat dipahami oleh orang-orang yang akan anda jadikan tim pengelolahan proyek media pembelajaran CD interaktif karena anda tidak akan bekerja sendiri bukan?

Sebagai contoh, dibawah ini disajikan bagaimana melakukan rancangan desain dalam bentuk bentuk story board. Anda harus memikirkn bagaimna layaknya anda adlah sutradara 
yang mengelolah story board. Anda tidak perlu berkecil hati jika anda belum melakukan desain yang maksimal karena memang di butuhkn banyak latihan dan pengalaman dalam penyusunan story board.

Dengan banyak latihan dan bnyak praktek, maka anda akan terbiasa mengelola story board sesuai dengan gaya anda senidiri. Dan saat nanti, anda akan mempunyai style sendiri yang menggambarkan ciri khas anda dalam melakukan desain media.

\begin{tabular}{|c|c|c|c|c|}
\hline \multirow{7}{*}{ SCENE1 LOGIN } & \multicolumn{2}{|r|}{ NAMA OBJEK } & \multirow{2}{*}{ TOMBOL } & \multirow[t]{2}{*}{ LINK } \\
\hline & OBJEK & JUDUL & & \\
\hline & image & login & ok & welcome \\
\hline & audio & instrumen"ayo belajar" & & \\
\hline & form & nama, login & & \\
\hline & animasi & rolling teks & & \\
\hline & video & - & & \\
\hline \multirow{6}{*}{ SCENE2 LOGIN } & OBJEK & JUDUL & LANJUT & Hal. Utama \\
\hline & image & login & & \\
\hline & audio & instrumen"ayo belajar" & & \\
\hline & form & nama, login & & \\
\hline & animasi & flash & & \\
\hline & video & video DIY & & \\
\hline dst & $\ldots$ & $\ldots$ & $\ldots$. & $\ldots$ \\
\hline
\end{tabular}

\section{Pembuatan Diagram Alir (Flow-Chart)}

Diagram alir adalah tool atau alat bentuk untuk mereprensikan cara anda dalam menyusun media. Diagram alir dapat emnjelaskan semua aliran dari suatu scene(tampilan) kescene yang lain secra lengkap. Untuk membuat diagram alir, anda dapat membuat kaidah kaidah dalam menyusun flowchart, bahkan anda dapat menggunakan versi anda sendiri.

Yang perlu di perhatkan dalam menyusun diagram alir tentunya diagram alir tersebutharusbersifatinformative, mampu menggambarkan keseluruhan proses yang harus di lakukan dan 
tentunya yang terpenting adalah tidak membingungkan anda sendiri ketika mulai melakukan penyusunan media.

Dibawah ini, adalah contoh bagaimna penyusunan diagram alir dilakukkan ssesuai dengan konsep dan desain yang sudah dilakukan pada tahap sebelumnya.

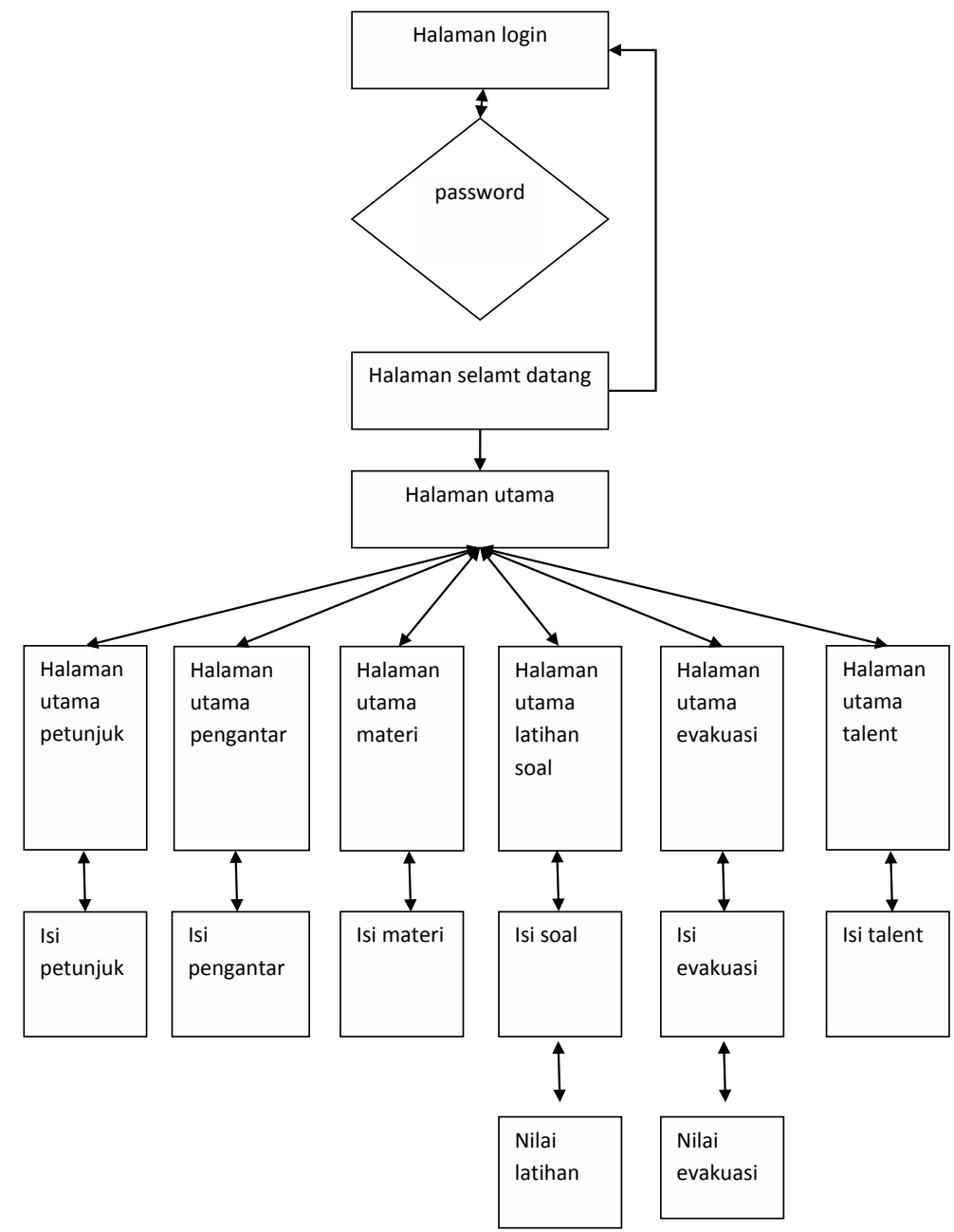




\section{Manajemen Directory}

Manajemen directory adalah pengelolaan direktory tempat semua objek media diintegrasikam dalam media anda. Objek-objek dikumpulkan sedemikian rupa sehingga mudah di gunakan pada saat media dikembangkan maupun pada saat media dijalankan.

Objek yang dikelompokkan dalam bentuk komponen umumnya terkait dengan jenis type file yang di gunakan. Objek video yang di peroleh dari luar atau aplikasi lain, ditempatkan pada direktory video. Objek flash movie[.swf] yang dibuat dengan macromedia flash atau movie [.swf] yang dibuat dengan swishmax ditempatkan pada directori animasi, termasuk di dalam nya adalah file bertipe .fla dan .Swi.

Objek video dan audio yang diperluas dapat disimpen ke root directory supaya dapat diakses oleh flash movie. File .dir yang merupakan file macromedia director MX, harus diletakan pula pada rood directory, dan seterusnya sehingga manajemen file dan directory dalam pengembangan media menjadi lebih mudah.

Untuk memudahkan semua penjelasan di atas, maka perhatikan contoh manajemen file dan directory dalam bentuk diagram di bawah ini.

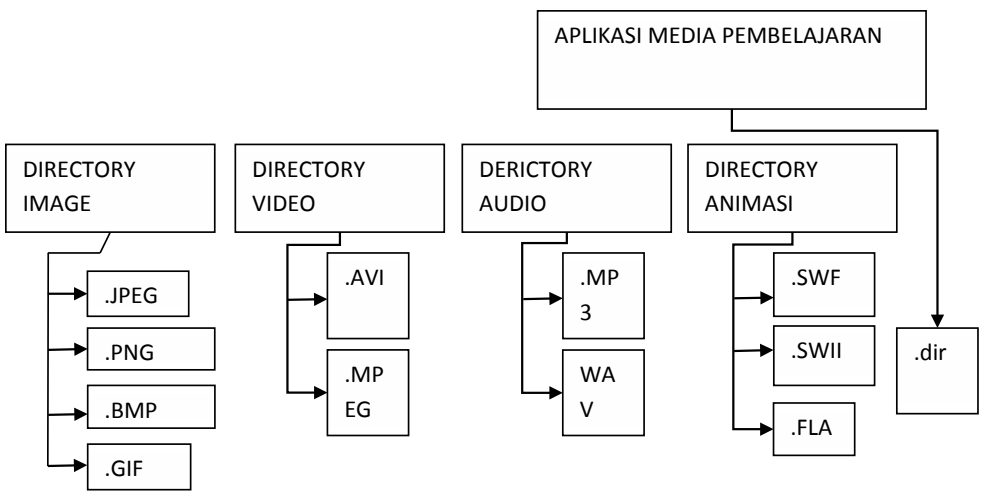




\section{Pengumpulan Bahan}

Pengumpulan bahan atau materi dapat dikerjakan secara pararel bersamaan dengan tahapan anda mengembangkan madeia. Pada tahap ini anda dapat mengumpulkan bahan seperti clip art image, animasi, audio, foto, video dan lain sebagainya yang akan anda lakukan gunakan dalam pengembangan media.

Pada saat mengumpulakan bahan, umunya yang terjadi adalah anda perlu melakukan beberapa perlakuan atau pengelola terhadap materi atau bahan yang sifatnya masih mentah. Biasanya dalam tahapan ini, anda mungkin saja membutuhkan software lain sebagi pendukung pengelola bahan yang mentah tersebut.

Sebagi contoh, mungkin saja pada saat anda mengumpulkan bahan, anda membutuhkan software tambahan seperti macromedia firework, adobe photoshop atau corel draw untuk mengelolah bahan-bahan grafik. Anda juga mungkin membutuhkan software. 


\section{BAB 4}

\section{DESAIN}

\section{PENGEMBANGAN}

MULTIMEDIA

\section{INTERAKTIF}

Dalam bab ini diuraikan mengenai:

[1] Desain Pengembangan

[2] Prosedur Pengembangan

[3] Uji Coba Produk

\section{Desain Pengembangan}

Model pengembangan prosedural yaitu model yang bersifat deskriptif yang menggariskan langkahlangkah yang harus diikuti untuk menghasilkan produk. Tahap-tahap pengembangan prosedural antara lain tahap perencanaan, pelaksanaan, dan penilaian produk. Sedangkan menurut Borg \& Gall, penelitian pengembangan adalah suatu proses yang digunakan untuk mengembangkan atau memvalidasi produk-produk yang digunakan dalam pendidikan dan pembelajaran.

Pengembangan difokuskan pada pengembangan media pembelajaran matematika yang dikemas dalam bentuk Compact Disc (CD). Model pengembangan 
media pembelajaran yang digunakan dalam penelitian ini menggunakan langkah-langkah yang diadaptasi dari Borg \& Gall sebagai berikut:

\begin{tabular}{|l|}
\hline Pendahuluan \\
Pelakukan \\
Penelitian \\
- Studi Pustaka \\
- Menentukan \\
jenis media \\
pembelajaran \\
yang akan \\
digunakan \\
\hline
\end{tabular}
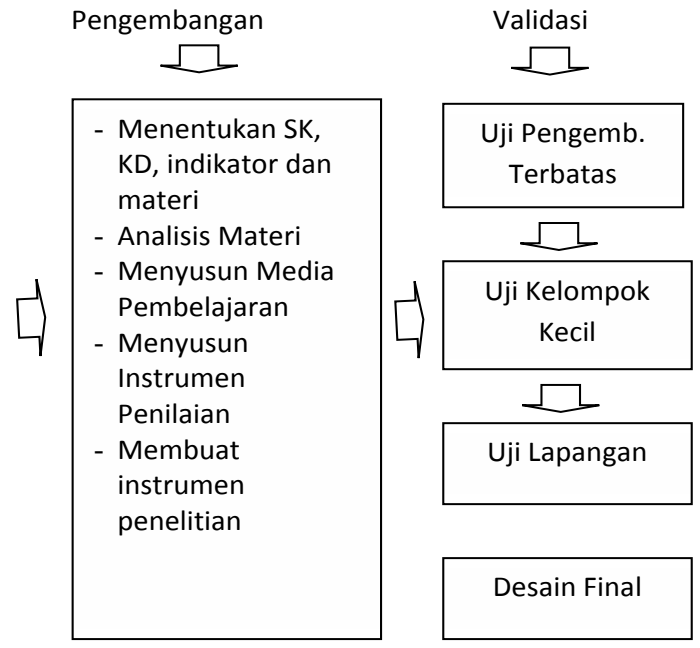

\section{Prosedur Pengembangan}

Prosedur pengembangan merupakan penjelasan dari model pengembangan yang telah ditetapkan. Penulis menitikberatkan pada pengembangan media pembelajaran matematika berupa CD pembelajaran interaktif. Langkahlangkah yang ditempuh dalam prosedur pengembangan antara lain:

1. Pendahuluan

a. Studi pustaka, yaitu mengkaji teori-teori dan hasil penelitian yang relevan sesuai dengan penelitian pengembangan yang akan dilakukan.

b. Menentukan jenis media pembelajaran yang akan digunakan. 
2. Pengembangan

a. Menentukan Standar Kompetensi (SK), Kompetensi Dasar (KD), indikator, dan pokok bahasan yang akan disajikan.

b. Menyusun naskah (story board) media pembelajaran.

c. Menyusun instrumen penelitian yang meliputi: angket untuk ahli, angket untuk siswa, dan lembar observasi.

d. Membuat media pembelajaran matematika yang nantinya akan divalidasi.

3. Validasi

a. Uji Pengembangan Terbatas

Melakukan uji awal terhadap desain produk oleh ahli bidang pembelajaran matematika, dan ahli bidang media pembelajaran.

b. Uji Kelompok Kecil

Uji kelompok kecil dilakukan untuk mengetahui efektivitas desain produk. Uji coba dilakukan pada 12 orang siswa yang mewakili kelompok dengan kemampuan tinggi, sedang, dan kurang. Hasil uji coba berupa desain yang efektif, baik dari sisi substansi maupun metodologi.

c. Uji Coba Lapangan dan Kelayakan

Uji coba dilakukan pada siswa SMA/MA dalam satu kelas tertentu. 


\section{Uji Coba Produk}

1. Desain Uji Coba

Uji coba dilakukan untuk mendapatkan data yang digunakan sebagai dasar untuk merevisi produk. Sebelum diujicobakan, produk dievaluasi oleh beberapa ahli. Uji coba lapangan dilakukan setelah mendapat validasi dari ahli dan masukan yang diperoleh dijadikan sebagai dasar untuk merevisi produk. Tujuan dari uji coba adalah untuk mengetahui kelayakan dari media pembelajaran yang dikembangkan. Adapun tahapan yang dilalui adalah:

a. validasi oleh ahli $\rightarrow$ ahli materi, pembelajaran dan media,

b. analisis konseptual,

c. revisi I

d. uji coba kelompok kecil,

e. analisis hasil uji coba kelompok kecil,

f. revisi II,

g. uji coba lapangan,

h. analisis hasil uji coba lapangan,

i. revisi III, dan

j. produk akhir.

2. Subyek Uji Coba

Responden uji coba kelompok kecil adalah 12 orang siswa SMA/MA yang mewakili kelompok dengan kemampuan tinggi, sedang, dan kurang. Sedangkan 
responden uji coba lapangan adalah siswa SMA/MA dalam suatu kelas.

\section{Instrumen Pengembangan}

Instrumen yang digunakan untuk mengumpulkan data pada pengembangan multimedia adalah:

a. angket untuk ahli, yaitu ahli materi, ahli pembelajaran, dan ahli media,

b. angket untuk siswa,

c. lembar observasi.

CONTOH INTRUMEN YANG DIGUNAKAN:

Tabel 1. Kisi-kisi Angket untuk Aspek Pendidikan

\begin{tabular}{|c|l|c|}
\hline No & \multicolumn{1}{|c|}{ Indikator } & $\begin{array}{c}\text { Item } \\
\text { soal }\end{array}$ \\
\hline 1 & Multimedia menyajikan topik yang jelas & 1 \\
\hline 2 & $\begin{array}{l}\text { Pembelajaran dalam multimedia sesuai } \\
\text { dengan tahap perkembangan siswa }\end{array}$ & 2 \\
\hline 3 & $\begin{array}{l}\text { Materi dalam multimedia relevan dengan } \\
\text { materiyang harus dipelajari siswa }\end{array}$ & 3 \\
\hline 4 & Isi materi mempunyai konsep yang benar & 4 \\
\hline 5 & $\begin{array}{l}\text { Multimedia memberikan umpan balik bersifat } \\
\text { positif dan korektif }\end{array}$ & 5 \\
\hline 6 & $\begin{array}{l}\text { Umpan balik tidak membuat siswa putus asa } \\
\text { jika menjawab salah }\end{array}$ & 6 \\
\hline 7 & $\begin{array}{l}\text { Umpan balik tampil di layar dalam waktu } \\
\text { yang sesuai }\end{array}$ & 7 \\
\hline 8 & $\begin{array}{l}\text { Multimedia mendorong siswa berusaha } \\
\text { memperoleh jawaban yang benar }\end{array}$ & 8 \\
\hline
\end{tabular}


Tabel 2. Kisi-kisi Angket untuk Aspek Tampilan Multimedia

\begin{tabular}{|c|l|c|}
\hline No & \multicolumn{1}{|c|}{ Indikator } & $\begin{array}{c}\text { Item } \\
\text { soal }\end{array}$ \\
\hline 1 & Pemakaian warna membantu pemahaman konsep & 9 \\
\hline 2 & Pewarnaan tidak mengacaukan tampilan layar & 10 \\
\hline 3 & Multimedia menggunakan karakter/huruf yang sesuai & 11 \\
\hline 4 & $\begin{array}{l}\text { Setiap tampilan merupakan kombinasi } \\
\text { komponen yang bekerja bersama sehingga } \\
\text { multimedia tampak jelas }\end{array}$ & 12 \\
\hline 5 & $\begin{array}{l}\text { Grafis membantu mengingat informasi/materi } \\
\text { yang dipelajari }\end{array}$ & 13 \\
\hline 6 & Grafis terlihat jelas dan mudah dipahami & 14 \\
\hline 7 & $\begin{array}{l}\text { Video/animasi membantu melihat kejadian yang } \\
\text { berhubungan dengan materi }\end{array}$ & 15 \\
\hline 8 & Suara terdengar jelas dan efektif & 16 \\
\hline 9 & $\begin{array}{l}\text { Perintah-perintah dalam multimedia bersifat } \\
\text { sederhana dan mudah dioperasikan }\end{array}$ & 17 \\
\hline 10 & Menu dan tombol dapat digunakan secara efektif & 18 \\
\hline 11 & Perpindahan antar layar sudah tepat & 19 \\
\hline 12 & Tampilan program tidak membosankan & 20 \\
\hline
\end{tabular}

Tabel 3. Kisi-kisi Angket untuk Aspek Teknis

\begin{tabular}{|c|l|c|}
\hline No & \multicolumn{1}{|c|}{ Indikator } & $\begin{array}{c}\text { Item } \\
\text { soal }\end{array}$ \\
\hline 1 & Multimedia dapat dimulai dengan mudah & 21 \\
\hline 2 & Anda merasa senang belajar dengan multimedia ini & 22 \\
\hline 3 & Anda tidak merasa bosan menggunakan program ini & 23 \\
\hline 4 & $\begin{array}{l}\text { Anda dapat mengulangi pada bagian pelajaran } \\
\text { yang diinginkan }\end{array}$ & 24 \\
\hline 5 & $\begin{array}{l}\text { Anda termotivasi belajar Matematika setelah } \\
\text { menggunakan multimedia pembelajaran ini }\end{array}$ & 25 \\
\hline
\end{tabular}




\section{Teknik Analisis Data}

Data yang diperoleh dalam penelitian ini akan dianalisis melalui tahapan sebagai berikut:

1. Data kualitatif yang diperoleh dari lembar observasi dianalisis secara kualitatif

2. Data yang diperoleh melalui angket untuk ahli dan angket untuk siswa yang berupa huruf diubah menjadi nilai kualitatif CD pembelajaran dengan langkah-langkah sebagai berikut:

a. Jenis data yang diambil yang berupa data kualitatif diubah menjadi kuantitatif dengan ketentuan yang dapat dilihat dalam tabel berikut:

Tabel 4. Data Kualitatif Dirubah ke Data Kuantitatif

\begin{tabular}{|l|c|}
\hline \multicolumn{1}{|c|}{ Keterangan } & Skor \\
\hline SB (sangat baik) & 5 \\
\hline B (baik) & 4 \\
\hline C (cukup) & 3 \\
\hline K (kurang) & 2 \\
\hline SK (sangat kurang) & 1 \\
\hline
\end{tabular}

b. Setelah data terkumpul, kita hitung skor rata-rata dengan rumus:

$\bar{X}=\frac{\sum X}{N}$

Keterangan: $\quad \begin{array}{ll}\bar{X} & =\text { Skor rata-rata } \\ \Sigma X & =\text { jumlah skor } \\ N & =\text { banyaknya penilai }\end{array}$


c. Mengubah nilai tiap aspekCD pembelajaran matematika menjadi nilai kualitatif sesuai dengan kriteria kategori penilaian ideal dengan ketentuan dalam table berikut.

Tabel 5. Kriteria Kategori Penilaian Ideal

\begin{tabular}{|c|c|c|}
\hline No & Rentang skor (i) kuantitatif & $\begin{array}{c}\text { Kategori } \\
\text { Kualitatif }\end{array}$ \\
\hline 1 & $\bar{X}_{>}\left(M_{i}+1,5 S B_{i}\right)$ & Sangat Baik \\
\hline 2 & $\left(M_{i}+0,5 S B_{i}\right)<\bar{X}_{\leq}\left(M_{i}+1,5 S B_{i}\right)$ & Baik \\
\hline 3 & $\left(M_{i}-0,5 S B_{i}\right)<\bar{X}_{\leq}\left(M_{i}+0,5 S B_{i}\right)$ & Cukup \\
\hline 4 & $\left.\left(M_{i}-1,5 S B_{i}\right)<\bar{X}_{\leq} M_{i}-0,5 S B_{i}\right)$ & Kurang \\
\hline 5 & $\bar{X}_{\leq}\left(M_{i}-1,5 S B_{i}\right)$ & Sangat Kurang \\
\hline
\end{tabular}

Keterangan:

Mi : rata-rata ideal yang dapat dicari dengan menggunakan rumus $M_{i}=\frac{1}{2} x$ (skor maksimal ideal + skor minimal ideal)

SBi : simpangan baku ideal yang dapat dicari dengan rumus $\mathrm{SBi}=\left(\frac{1}{2} \mathrm{x}^{\frac{1}{3}}\right) \times($ skor maksimal ideal - skor minimal ideal $)$

Skor maksimal ideal $\quad={ }^{\Sigma}$ butir kriteria $\mathrm{x}$ skor tertinggi Skor minimal ideal $\quad={ }^{\Sigma}$ butir kriteria $\mathrm{x}$ skor terendah d. Menentukan nilai keseluruhan CD pembelajaran 
dengan menghitung skor rata-rata seluruh aspek. Kemudian diubah menjadi nilai kualitatif pembelajaran sesuai dengan kriteria kategori penilaian ideal seperti dijabarkan pada tabel di atas. Hasil persentase kriteria kategori penilaian ideal dapat dilihat pada Tabel berikut:

Tabel 6. Persentase Kriteria Kategori Penilaian Ideal

\begin{tabular}{|c|c|c|}
\hline No & Rentang skor (i) kuantitatif & Kategori kualitatif \\
\hline 1 & $\bar{X}_{>80 \%}$ & Sangat Baik \\
\hline 2 & $66,6667 \%{ }^{<} \bar{X}_{\leq 80 \%}$ & Baik \\
\hline 3 & $53,3334 \%{ }^{\bar{X}_{\leq}} \leq 66,6667 \%$ & Cukup \\
\hline 4 & $40 \% \bar{X}_{\leq 53,3334 \%}$ & Kurang \\
\hline 5 & $\bar{X}_{\leq 40 \%}$ & Sangat Kurang \\
\hline
\end{tabular}

3. Hasil analisis data yang diperoleh dijadikan sebagai dasar untuk mengetahui kualitas produk yang dihasilkan. 



\section{BAB \\ MENGENAL \\ MACROMEDIA FLASH PROFESSIONAL 8}

Dalam bab ini diuraikan mengenai:

[1] Dasar-Dasar Macromedia Flash Professional 8

[2] Teknik-Teknik Pembuatan Animasi Dasar Mengunakan Macromedia Flash 8.

\section{Dasar-Dasar Macromedia Flash Professional 8}

Macromedia Flash Professional 8 adalah sebuah program animasi yang telah banyak digunakan oleh para Animator untuk menghasilkan animasi yang profesional. Di antara program-program profesional 8 merupakan programprogram animasi, program Macromedia Flash Professional 8 merupakan program yang paling fleksibel dalam pembuatan animasi, seperti animasi interaktif, game, company profile, presentasi, movie, dan tampilan animasi lainnya.

Macromedia Flash Professional 8 merupakan versi terbaru dari seri sebelumnya, yaitu Macromedia Flash MX 2004. Versi terbaru ini menyajikan banyak sekali perubahan tampilan, peranti baru, filter, blend mode, dan fasilitas lainnya. 
Keunggulan dari program Macromedia Flash Professional 8 dibanding program lain yang sejenis, antara lain:

- Dapat membuat tombol interaktif dengan sebuah movie atau objek yang lain.

- Dapat membuat perubahan transparasi warna dalam movie.

- Dapat membuat perubahan animasi dari satu bentuk ke bentuk lain.

- Dapat membuat gerakan animasi dengan mengikuti alur yang telah ditetapkan.

- Dapat dikonversi dan dipublikasikan (publish) ke dalam beberapa tipe, di antaranya.swf,.html,.jpg,.png,.exe,.mov.

- Dapat mengolah dan membuat animasi dari objek Bitmap.

- Pembuatan objek-objek vektor.

Berikut ini tampilan file atau dokumen baru dari area kerja Macromedia Flash Pro8:

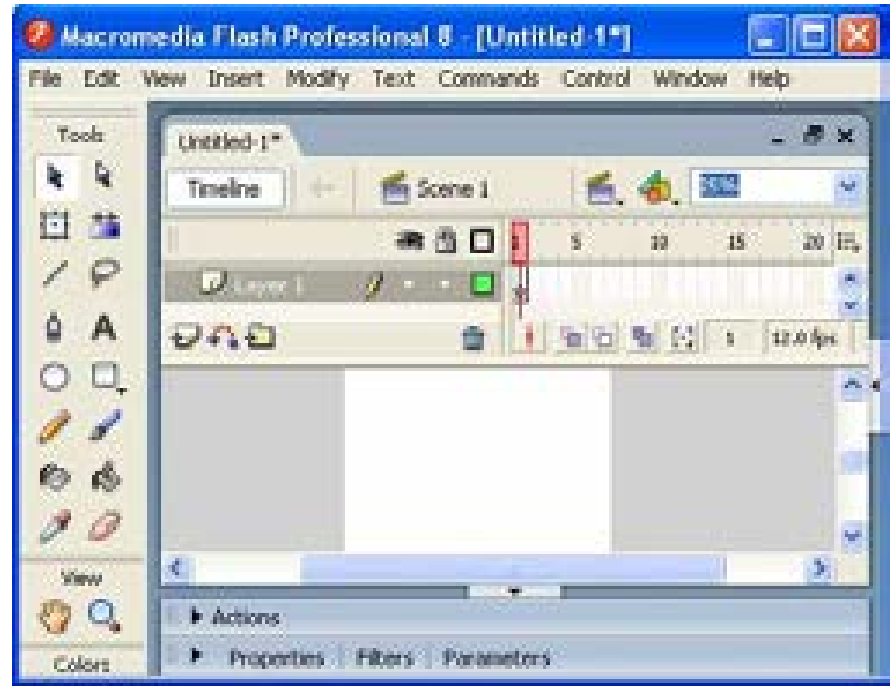


Elemen dasar Macromedia flash8 terdiri dari lima area kerja, yaitu: Menu, Toolbox, Timeline, Stage, Property dan Panels. Deskripsi dan fungsi masing-masing area adalah sebagai berikut:

1. Menu berisi kontrol untuk berbagai fungsi seperti membuat, membuka, dan menyimpan file, dan lain-lain.

2. Tolbox berisi koleksi untuk membuat atau menggambar, memilih dan memanipulasi isi stage dan timeline. Toolbox dibagi (lagi) menjadi empat bagian, yaitu Tools, View, Colors, dan Options. Beberapa tool mempunyai bagian option. Contohnya ketika Arrow tool dipilih, options snap, smouth, straighten, rotate, dan scale akan muncul.

3. Timeline adalah tempat membuat dan mengontrol objek dan animasi.

4. Stage adalah area persegi empatyang merupakan tempat membuat objek atau animasi yang akan dimainkan.

5. Property berisi informasi yang digunakan untuk menentukan ciri-ciri sesuatu objek atau movie yang akan kita hasilkan.

6. Panels berisi kontrol fungsi yang dipakai untuk mengganti dan memodifikasi berbagai property objek atau animasi secara cepat dan mudah.

1. Menu bar

Menu Bar merupakan baris menu yang berisi perintah berupa menu-menu yang aktif dimulai dari menu File sampai dengan Help. Masing-masing menu mempunyai sub menu atau perintah, seperti yang tampak pada Gambar dibawah. 
2. Toolbox

Dalam toolbox terdapat komponen-komponen penting diantaranya: Tools, View, Colors dan Options. Toolbox memiliki peran untukmemanipulasi atau memodifikasi objek dalam stage. Berikut komponen-komponen dalam toolbox beserta fungsi atau kegunaannya:

1) Selection Tool: memilih dan memindahkan objek.

2) Subselection Tool: mengubah bentuk objek dengan edit points

3) Free Transform Tool: mengubah atau memutar bentuk objek sesuai keinginan

4) Gradient transform Tool: mengubah warna gradasi

5) Line Tool: membuat garis

6) Lasso Tool: menyeleksi bagian objek yang akan diedit

7) Pen Tool: membuat bentuk objek secara bebas berupa dengan titik titik sebagai penghubung

8) Text Tool: membuat teks

9) Oval Tool: membuat objek elips ataupun lingkaran

10) Ractangle Tool: membuat objek berbentuk segi empat atau segi banyak, dan juga bintang.

11)Pencil Tool:menggambar objek secara bebas

12)Brush Tool: Menggambarobjek secarabebas dengan ukuran ketebalandan bentukyangsudah disediakan

13)Ink Bottle Tool: member warna garis tepi (outline)

14)Paint Bucket Tool: member warna padsa objek secara bebas 
15) Eyedropper Tool:menyedot atau mengambil contoh warna 16)Eraser Tool: menghapus Objek

17)Hand Tool: Menggeser Stage

18)Zoom Tool: memperbesar dan juga memperkecil objek 19) Stroke Color: member warna pada garis tepi 20)Fill Color: member warna pada objek

3. Timeline

Timeline atau garis waktu merupakan komponen yang digunakan untuk mengatur atau mengontrol jalannya animasi. Timeline terdiri dari beberapa layer. Layer digunakan untuk menempatkan satu atau beberapa objek dalam stage agar dapat diolah dengan objek lain. Setiap layer terdiri dari frameframe yang digunakan untuk mengatur kecepatan animasi. Semakin panjang frame dalam layer, maka semakin lama animasi akan berjalan.

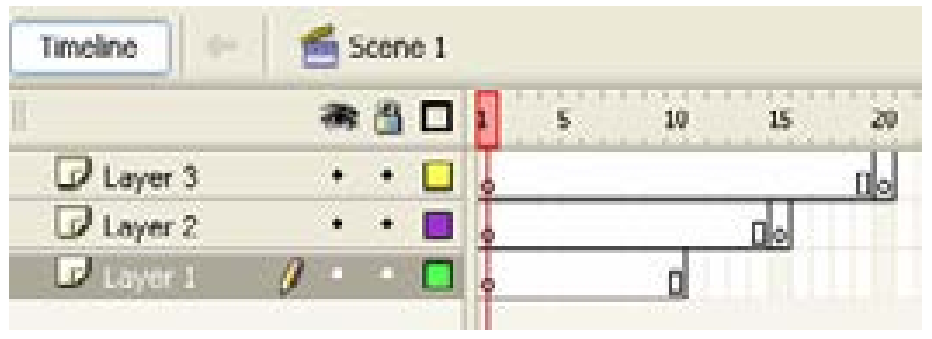

Gambar Layer dan frame pada Timeline

4. Stage. Stage disebut juga layar atau panggung. Stage digunakan untuk memainkan objek-objek yang akan diberi animasi. Dalam stage kita dapat membuat gambar, teks, memberi warna dan lain-lain. 
5. Panel. Beberapa panel penting dalam Macromedia Flash Pro 8 diantaranya panel: Properties \& Filters \& Parameters, Actions, Library, Color dan Align \& Info \& Transform.

1) Panel Properties \& Filters \& Parameters

Panel ini terdapat dibawah stage. Untuk mengeluarkan atau menyembunyikan panel ini dapat digunakan shortcut Ctrl+F3. Panel Properties \& Filters \& Parameters digunakan untuk untuk mengatur ukuran background,warna background,kecepatan animasi dan lain-lain.

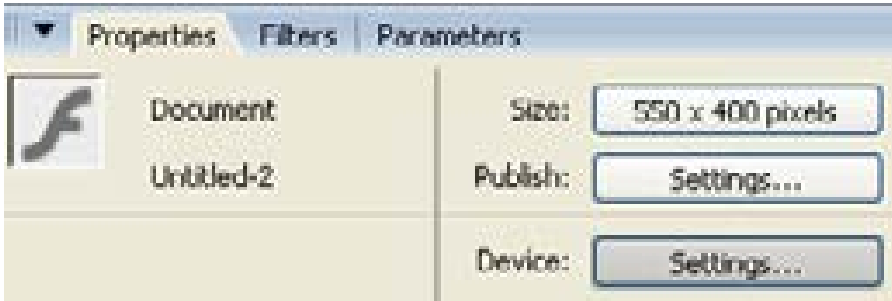

Gambar Panel Properties \& Filters \&

Parameters

2) Panel Actions

Panel Actions digunakan untuk menuliskan script atau bahasa pemrograman flash (Action Script). Anda dapat mengetikkan secara langsung pada layar Actions atau menggunakan bantuan yang disediakan oleh Macromedia Flash Pro 8. Untuk memunculkan atau menyembunyikan panel ini dapat digunakan shortcut F9. 


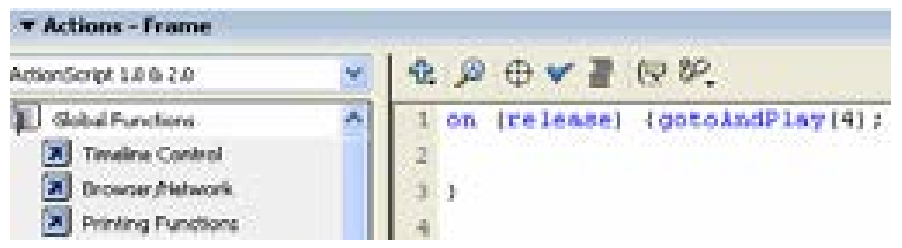

Gambar Panel Actions untuk membuat Action Script

3) Panel Library

Library merupakan panel yang digunakan untuk menyimpan objek-objek berupa graphic atau gambar, button atau tombol, movie dan suara baik yang dibuat langsung pada stage ataupun hasil proses impor dari luar stage. Untuk memunculkan atau menyembunyikan panel ini dapat digunakan shortcut Ctrl+L.

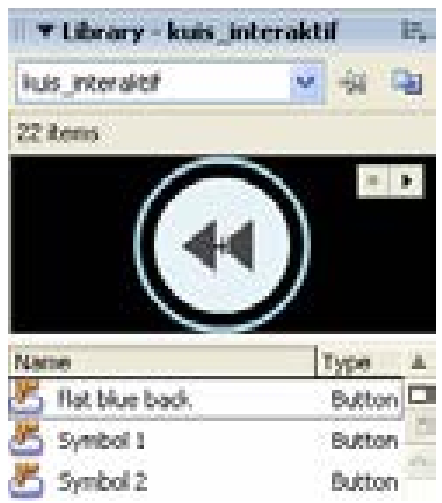

Gambar Panel Library

4) Panel Color

Panel Color merupakan panel yang digunakan untuk memilih warna yang digunakan dalam pembuatan objek-objek pada stage. Ada dua jenis subpanel, yaitu: Color Mixer dan Swatches. Shortcut untuk 
Color Mixer adalah Shift+F9 dan shortcut untuk Color Swatches adalah Ctrl+F9.

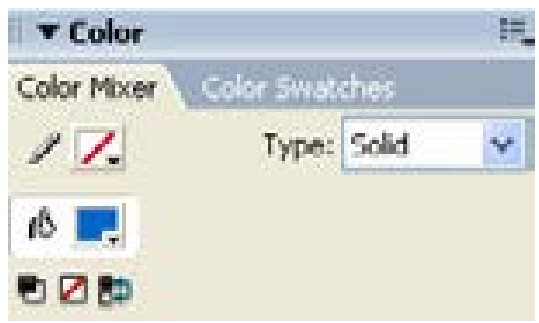

Gambar Bagian dari panel Color

5) Panel Align \& Info \& Transform

Untuk menampilkan panel ini Anda dapat menekan $\mathrm{Ctrl}+\mathrm{K}$ pada keyboard. Panel ini digunakan untuk mengatur posisi objek, ingin diletakkan pada tengah stage, sebelah kiri atau kanan dan lainlain. Dengan panel ini Anda juga dapat memutar objek dengan Transform.

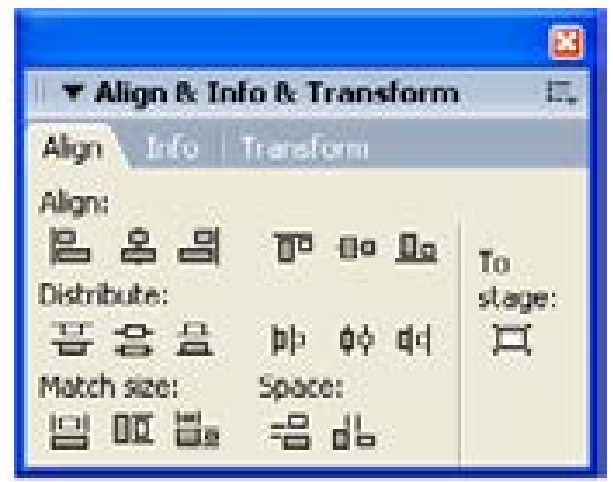

Gambar Bagian dari panel Align \& Info \& Transform 


\section{Teknik-Teknik Pembuatan Animasi Dasar Mengunakan Macromedia Flash 8.}

Berikut akan dijelaskan teknik-teknik pembuatan animasi dasar mengunakan Macromedia Flash 8.

\section{Animasi Dasar Motion Tween}

Animasi ini merupakan animasi yang paling dasar karena animasi ini pada prinsipnya adalah pergerakan suatu objek (motion), seperti halnya definisi animasi yaitu teks/ gambar yang bergerak.

Langkah 1: Buat objek lingkaran menggunakan OvalTool (C+O) Langkah 2: Seleksi objek menggunakan Selection Tool $(\mathrm{C}+\mathrm{V})$ atau Ctrl+A, untuk menyeleksi objek lingkaran. Setelah itu, klik kanan Convert to symbol pilih Movie Clip

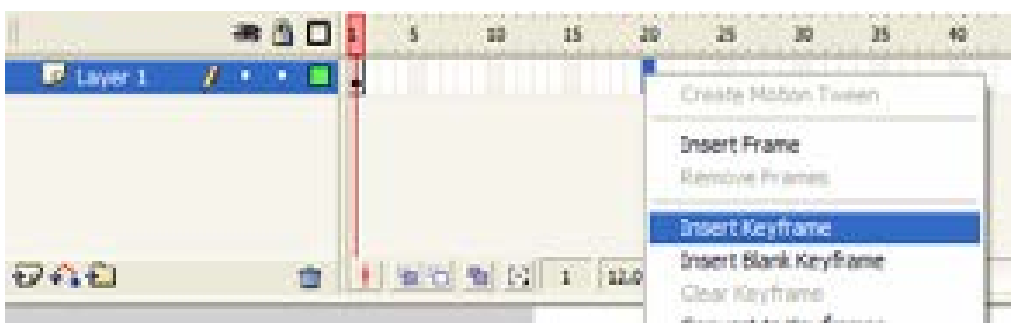

Jendela dialog Convert to Symbol (F8)

Langkah 3:

Pilih frame 20 pada Layer 1 di Timeline, setelah itu klik kanan dan Insert Keyframe. Geser objek kearah kanan kembalikan objek ke frame 1 


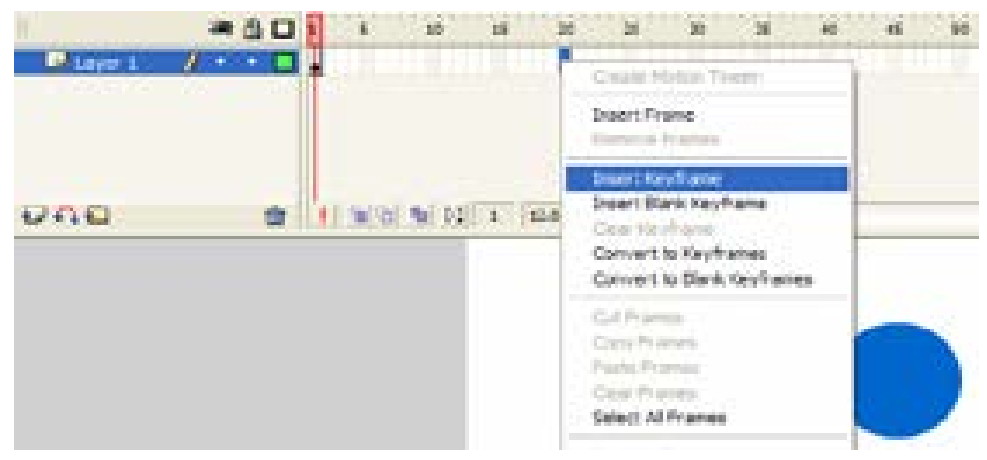

Gambar Insert Keyframe (F6)

Langkah 4:

Pada Properties dibawah stage pilih Tween Motion. Jika langkah benar, maka dibagian layer1 akan muncul panah dari frame 1 ke frame 20. Untuk menjalankan animasi: Enter atau Ctrl+Enter untuk melakukan Test Movie.

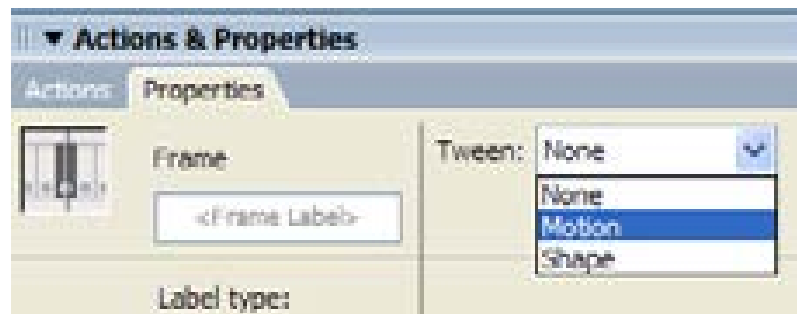

Jendela Dialog Pemilihan Jenis Animasi

Untuk menghentikan test movie $\mathrm{Ctrl}+\mathrm{W}$

\section{CATATAN:}

Animasi berhasil jika dalam layer terdapat tanda panah ( ). Jika belum berhasil (garis dalam layer berupa garis putusputus), ulangi langkah Anda sampai berhasil!

Sebagai latihan dengan jenis motion tween Anda dapat membuat: Animasi bola pantul. 
Animasi tersebut berupa bola yang berpantul dari suatu titik ketitik yang lain, misalnya dari titk A ke B, dari B ke $C$ dan seterusnya. Untuk pengembangan Anda juga dapat menambahkan background/gambar latar belakang, caranya dengan menambahkan layer baru yang dilengkapi dengan keyframe sepanjang objek tersebut berjalan.

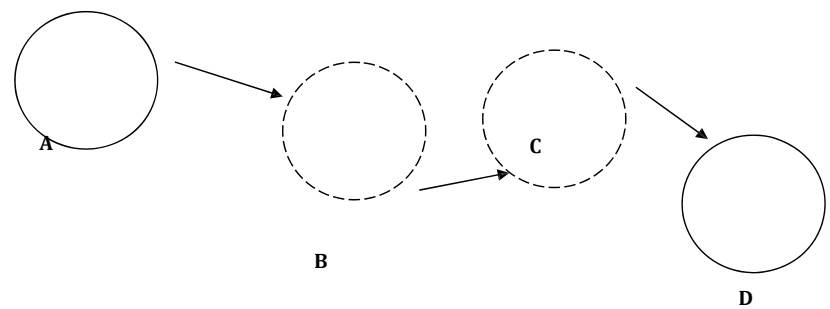

\section{Animasi Motion Shape}

Animasi bentuk/shape dibedakan menjadi 2 bagian yaitu:

a. Animasi bentuk dengan objek statis/diam di tempat

b. Animasi bentuk dengan objek dinamis/bergerak (ada motion-nya)

Yang perlu diperhatikan ketika Anda akan membuat animasi bentuk baik yang statis ataupun dinamis adalah bahwa objek tidak perlu di Convert to Symbol.

a. Animasi Bentuk Statis. Langkah-langkahnya:

Langkah 1: Buat objek lingkaran dengan Oval Tool.

Langkah 2: Klik Frame 30, kemudian Insert Keyframe.

Langkah 3: Ubah bentuk lingkaran menjadi bentuk bukan lingkaran, menggunakan subselection tool.

Langkah 4: Klik frame 1, pilih tween-shape dibawah stage. 
Langkah 5: Tekan Enter untuk Play atau Ctrl+Enter untukTest Movie.

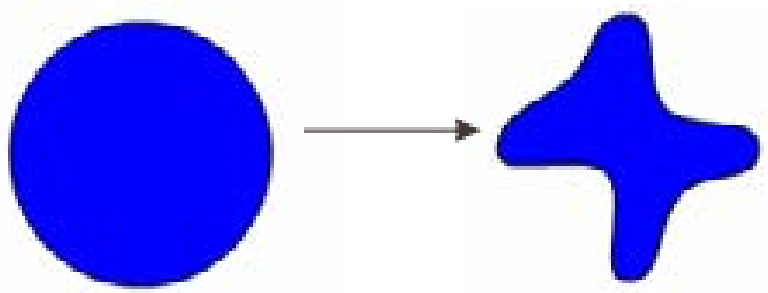

Perubahan bentuk objek dari Frame 1 ke Frame 30 b.Animasi Bentuk Dinamis

Jenis animasi ini merupakan pengembangan dari animasi bentuk statis. Pada jenis animasi ini akan diberikan contoh objek kotak berubah menjadi teks kotak.

Langkah-langkahnya adalah:

Langkah 1: Buat bentuk objek bentuk kotak di frame 1 menggunakan rectangle tool.

Langkah 2: Klik frame 40, insert keyframe.

Langkah 3: Pindahkan objek kotak dari frame 1 ke frame 40 setelah itu hapus objek dengan Delete.

Langkah 4: Masih di frame 40, buat teks KOTAK, lalu tekan Ctrl+B (2x), agar teks terkonversi menjadi objek.

Langkah 5: Kembali ke frame 1, pilih tween-shape, tekan Enter.
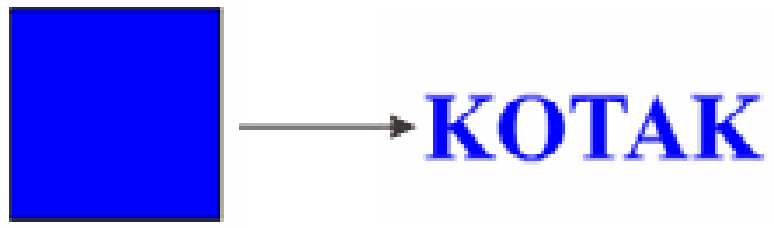

Gambar Perubahan objek kotak menjadi teks "KOTAK" 
Sederhana dan mudah bukan?

Untuk pengembangan Anda dapat membuat animasi berikut:

i. Animasi Tumbukan Fisika

Ilustrasi:

Objek mobil bergerak dari titik A ke titik B. Objek truk bergerak dari C ke B. Titik B merupakan titik tengah A dan C. Dititik B kedua objek bertemu dan terjadi tumbukan. Namun karena objek truk lebih besar dan kuat maka objek truk hanya bergerak beberapa meter saja,sedangkan objek mobil terpelanting jauh.

Bagaimanakan animasinya? Berkhayalah

ii. Animasi Bola Sodok

Ilustrasi:

Buatlah background area billiard dengan satu stick dan 2 bola, misalnya bola A dan B. Setelah itu stick akan menyodok bola A dan mengenai bola B, bola A dan bola B sama-sama terpental hanya karena menyodoknya tidak terlalu keras, maka bola A terpental lebih pendek daripada bola B. Bagaimanakah animasinya?

Animasi ini dapat dikembangkan dengan jumlah bola lebih banyak, area billiard ada lubangnya dan bola yang disodok berturutan dan lebih banyak.

\section{Animasi Motion Path}

Animasi ini merupakan dasar dari animasi game balapan mobil atau motor, yaitu bahwa mobil/motor bergerak mengikuti jalur/track yang sudah ditentukan. Hati-hati dalam membuat animasi ini, karena langkah tidak sesuai prosedur, maka animasi tidak akan berhasil. 
Langkah-langkah:

Langkah 1: Buat objek persegi menggunakan rectangle tool dan convert object to symbol(F8), pilih Movie Clip

Langkah 2: Klik kanan pada layer 1, pilih Add Motion Guide

Langkah 3: Buat jalur bebas menggunakanPencil Tool di layer guide Langkah 4: Gunakan Selection Tool, klik frame 30, dan insertkeyframe di layer guide

Langkah 5: Pilih kembali layer 1, frame 1, pindahkan objek kepangkal jalur, posisikan objek dengan tepat, sehingga terlihat lingkaran kecil di tengah-tengah objek persegi



Gambar Posisi layer dan Guide Layer

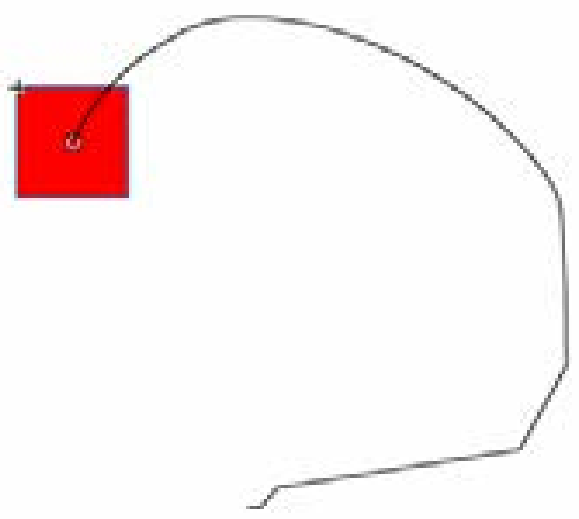

Gambar Posisi Objek setelah diletakkan dipangkal jalur 
Langkah 6: Klik frame 30 pada layer 1, lalu Insert Keyframe Langkah 7: Pindahkan objek dari pangkal ke ujung sesuai jalur yang dibuat, hati-hati pada langkah ini!

Langkah 8: Klik kembali frame 1 pada layer 1 kemudian pilih Tween Motion

Langkah 9: Tekan Enter untuk Play animasi yang baru saja Anda buat, jika belum berhasil ulangi langkah-langkah tersebut

Masih banyak animasi-animasi yangdapat dibuat dengan Macromedia Flash, namun langkah-langkah yang diberikan diatas kiranya dapat menjadi panduan bagi pemula yang ingin belajar animasi Flash. Selamat mencoba, semoga berhasil.... 


\section{MEMBANGUN MULTIMEDIA INTERAKTIF}

Latihan:

Buatlah seperti berikut ini :

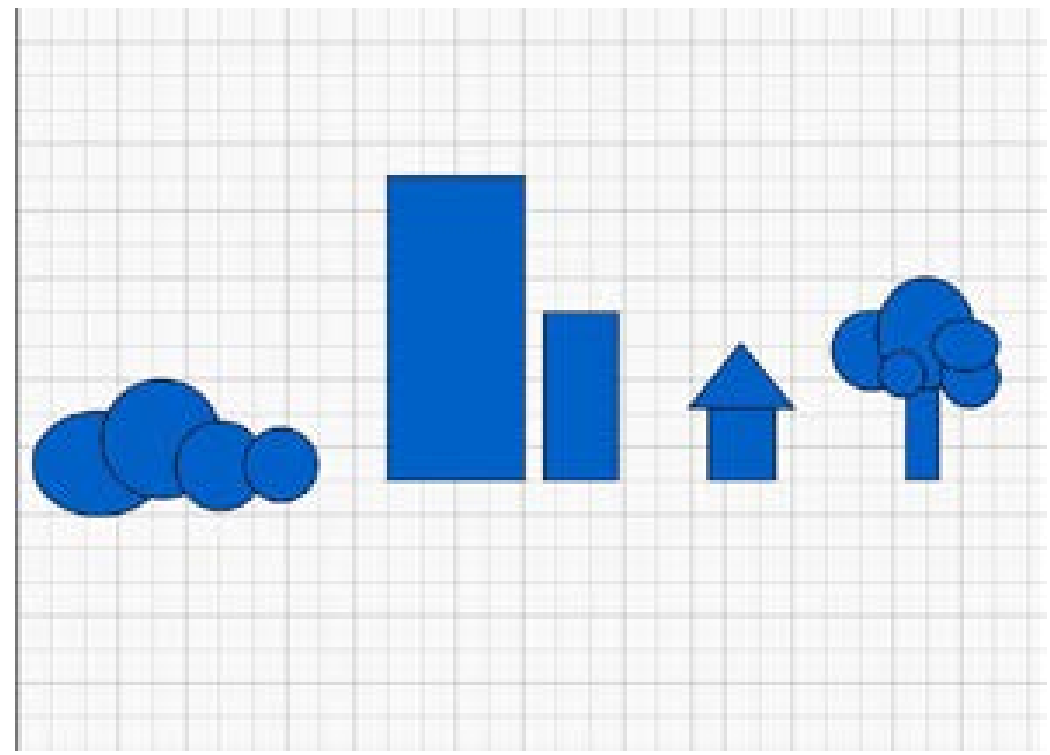

Caranya:

a) Buka macromedia flash. Pada gambar diatas terlihat beberapa objek yaitu: gedung, rumah dan pohon. Objek tersebut bisa kita bangun dengan menggunakan Tools: oval tool dan rectaangle tool.

b) Untukmembuat sebuah objek (lingkaran atapun persegi) yang simetris maka ketika kita sedang menggambarnya di stage jangan lupa dengan menahan tombol shift.

c) Buatlah objek diatas dengan warna outline adalah hitam dan warna Fill biru (atau terserah peserta).

d) Setelah itu modifikasi gambar hingga tampak seperti berikut ini : 


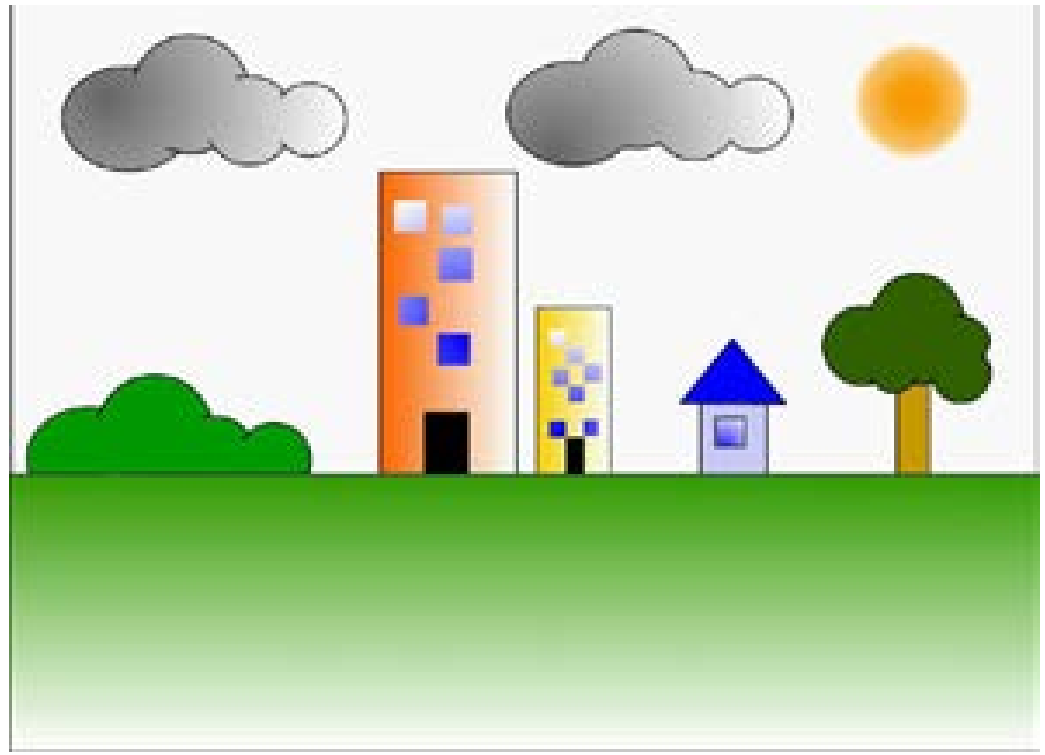

e) Untuk membuat gambar berkesan dengan warna gradasi, gunakan color mixer dengan tipe linier. Atur dua buah warna yang akan digunakan.

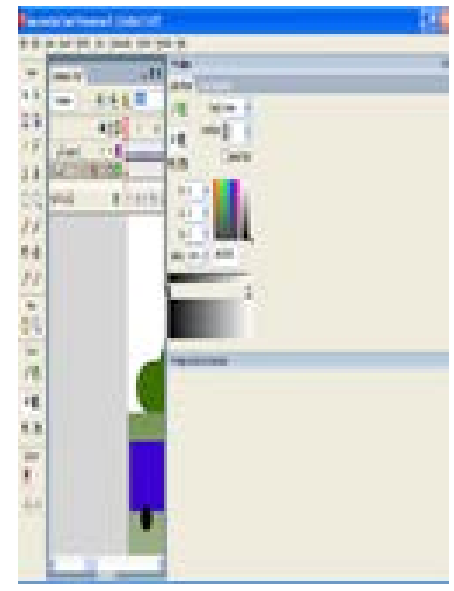

f) Jika sudah selesai membuat warna yang gradasi, maka buatlah sebuah layer baru. 
g) Buatlah sebuah objek di frame 1 layer 2 dengan terlebih dahulu mengunci layer 1 . Objek yang kita buat adalah sebuah mobil. Mobil ini akan kita coba jalankan dengan gambar latar belakang gedung yang tadi kita buat. Sehingga hasil akhirnya seperti ini:

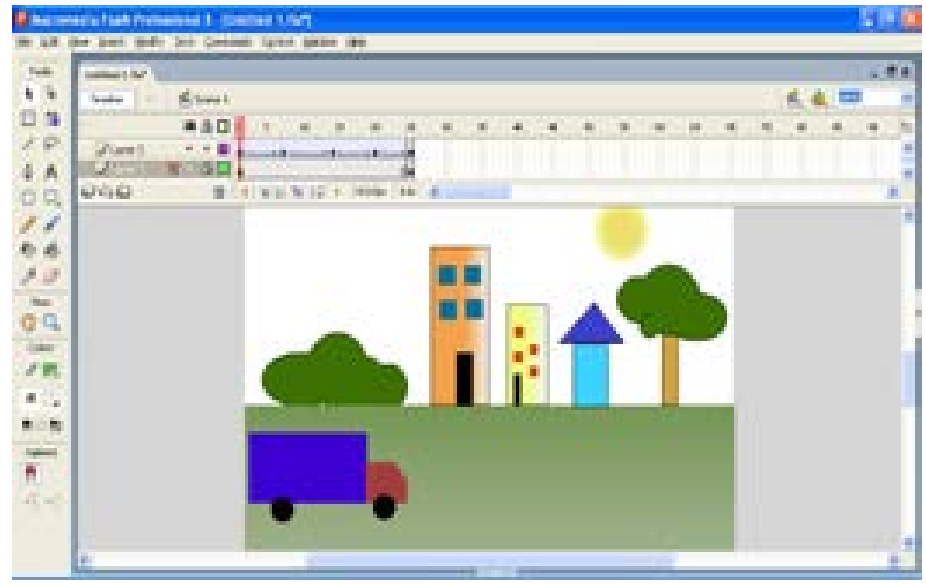

h) Cobalah usahakan sendiri membuat truk seperti gambar diatas. Tools yang digunakan adalah:rectaangle, oval dan line tool.Sesudah membuat truk, blok gambar truk kemudian satukan objek tersebut dengan menggunakan CTRL+G (group).

i) Agar pemandangan berjalan lama dalam frame maka panjangkan framenya dengan cara klik kanan pada frame ke 20, pilih insert keyframe.pada layer kedua frame kelima klik kanan pilih insert keyframe.geser objek truk ke sisi kanan dengan cara menahan SHIFT dan geser truk ke kanan, lakukan proses yang sama dengan frame ke-5 pada frame ke-10,15 dan frame ke-20. 
j) Pada frame antara 1 dengan 5, klik kanan pilih create motion tween. Lakukan hal yang sama untuk frame antara 5 dan 10, 10 dan 15 serta 15 dan frame 20.

k) Untuk melihat hasil akhirnya, silahkan tekan tombol CTRL+ENTER 



\section{MEMBUAT TOMBOL (BUTTON)}

Dalam bab ini diuraikan mengenai:

[1] Cara Membuat Tombol (Button) dalam Macromedia Flash Professional 8

Button adalah salah satu type dari symbol. Button digunakan untuk membuat tombol di flash. Dengan dijadikannya suatu objek menjadi button maka selain objek tersebut menjadi tombol, objek tesebut juga dapat menggunakan beberapa fasilitas dari flash seperti animasi tween, masking, guide dan juga kita dapat memberikan actionscript pada objek tersebut. Di bawah ini kita akan mempelajari cara dasar membuat tombol. Melalui cara dasar ini anda dapat berkreasi untuk membuat tombol yang bagus dan keren.

1. Buatlah sebuah flash document.

2. Buatlah sebuah lingkaran seperti gambar dibawah ini:




3. Seleksi lingkaran tersebut kemudian tekan F8 pada keyboard atau bisa juga melalui Modify>Convert to Symbol...

4. Pada kotak dialog yang muncul pilih Button sebagai Typenya seperti gambar dibawah ini :

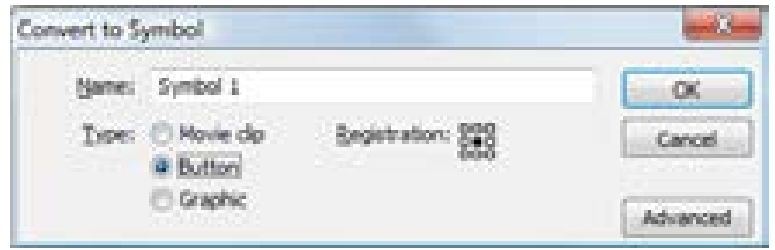

5. Ubah Name pada kotak dialog tersebut jika diperlukan, kalau sudah selesai tekan OK maka lingkaran yang anda buat tadi sudah berubah menjadi sebuah Symbol bertype Button.

6. Klik dua kali Button tadi maka anda akan masuk ke stagebutton.

7. Anda akan melihat jendela Timeline seperti gambar dibawah ini :

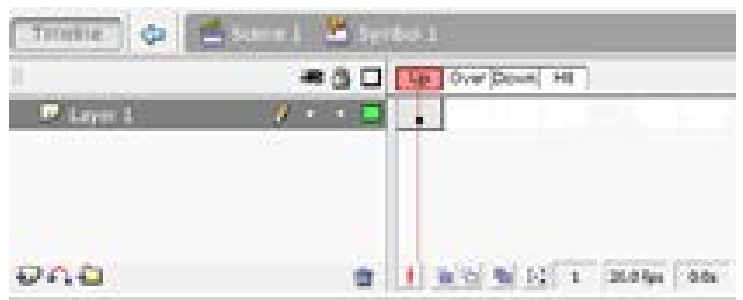

Up : tampilan utama button

Over : tampilan button ketika kursor mouse berada diatas button

Down : tampilan button ketika kursor mouse menekan button

Hit : luas daerah aktif button 
8. Pilih bagian Over, kemudian tekan F6 pada keyboard. Ubah warnalingkaran menjadi lebih muda

9. Pilih bagian Down, kemudian tekan F6 pada keyboard. Ubah warnalingkaran menjadi lebih tua

10. Jika anda ingin daerah aktif button menjadi lebih luas, pilih bagian Hit kemudian tekan F6 pada keyboard. Buatlah lingkaran yang ada menjadi lebih besar.

11. Kalau sudah selesai, klik tombol scene pada timeline atau bisa juga tekan CTRL+E pada keyboard.

12. Terakhir test movie dengan menekan CTRL+ENTER. 



\section{UISCROLLBAR}

Dalam bab ini diuraikan mengenai:

[1] Membuat teks yang bisa discroll.

Uiscrollbar adalah salah satu dari component user interface di flash yang digunakan untuk membuat scrolling text/teks yang dapat di scroll. Kelebihan dari component ini terdapat dalam kemudahan pemasangannya. Sedangkan kekurangannya adalah bentuk scrollingnya yang tidak dapat dimodifikasi/diubah. Berikut cara sederhana menggunakan uiscrollbar untuk scrolling text dengan scrolling yang terdapat pada sebelah kanan text:

1. Buatlah sebuah dynamic text di stage dengan menggunakan Text Tool. Seleksi dynamic text tersebut dan tekan Ctrl+F3. Pada panel properties yang muncul, ubah Line type menjadi Multiline, serta aktifkan tombol Selectable (agar teks dapat di scroll menggunakan roll mouse), Render text as HTML, dan juga Show border around text (memunculkan garis di dynamic text) sehingga pada panel properties akan tampak seperti di bawah ini: 


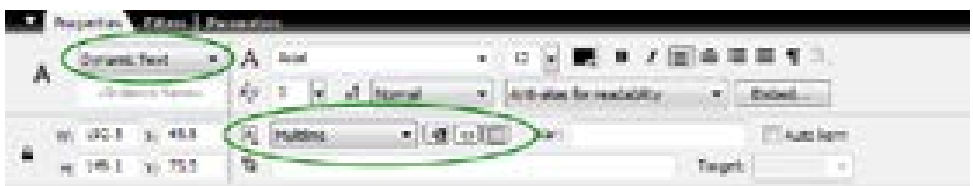

2. Buka panel component dengan menekan Ctrl+F7. Tekan tanda + di samping User Interface untuk menampilkan component di dalamnya. Drag uiscrollbar ke dalam dynamic text sebelah kanan.

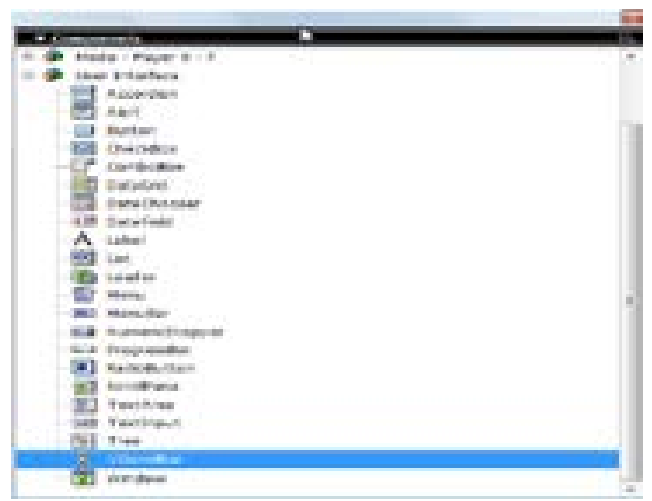

3. Masukkan tulisan ke dalam dynamic text. Masukkan tulisan yang cukup panjang, apabila tulisan kurang panjang maka text tidak bisa di scroll.

4. Tekan Ctrl+Enter untuk melihat hasilnya : 


\section{MEMBUAT \\ PASSWORD}

Dalam bab ini diuraikan mengenai:

[1] Membuat Pasword dalam Macromedia Flash Professional 8

Password digunakan untuk melindungi data-data agar hanya bisa dibuka oleh pemiliknya saja. Hal serupa dapat kita lakukan di Flash. Kita dapat membuat sebuah form Password yang kita tempatkan saat swf tampil sehingga ketika password yang dimasukan salah maka swf tidak bisa dijalankan. Tutorial mengenai bentuk dasar form password tersebut dapat anda lihat di bawah ini :

1. Buatlah 3 buah Blank Keyframe (seleksi 3 buah frame lalu tekan F7) dan berikan script berikut pada ketiga Blank Keyframe tersebut :

1 stop ();

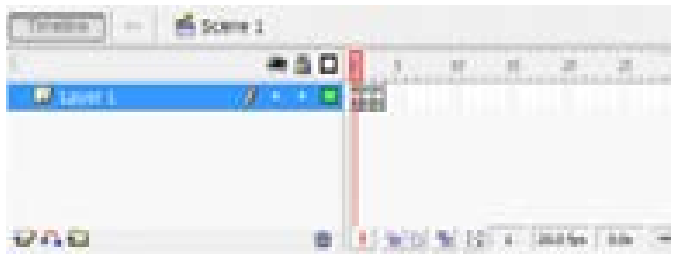


2. Pilih frame 1 dan buatlah sebuah Static Text bertuliskan Password:

3. Buatlah sebuah Input Text dengan Var : jawaban. Berikan angka 11 pada Maximum characters (hal ini akan membuat jumlah huruf/angka yang dapat dimasukan di Input Text hanya 11 karakter) dan ubah Line type menjadi Password (hal ini akan membuat huruf/angka yang dimasukkan tulisannya akan berbentuk* , jika anda tidak ingin tulisannya berbentuk * maka pilih Single Line sebagai Line Type)

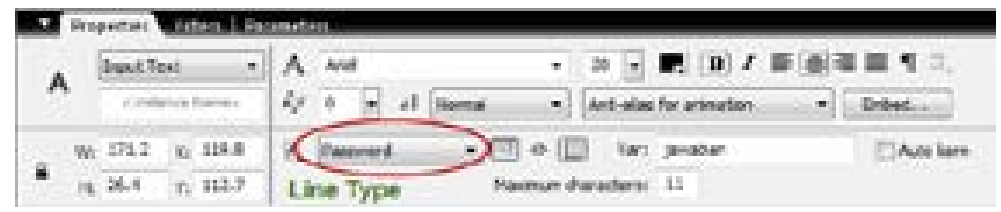

4. Masih di Frame 1 buatlah sebuah Symbol Button bertuliskan OK dan masukan script berikut pada Button tersebut : 1

2

3

4

5

6

7

8

9

10

5. Pindah ke Frame 2, buatlah sebuah Static Text bertulisakan Password yang anda masukan benar

6. Buatlah sebuah Symbol Button bertuliskan Back dan berikan script berikut pada button tersebut : 
1 on (release)

2

//jawaban dikosongkan

3

jawaban = " ;

4

//mainkan frame 1

5

gotoAndStop (1);

6

7. Copy seluruh objek-objek yang ada di Frame 2. Lalu pindah ke Frame 3 dan paste-kan yang tadi dicopy.

8. Ubah Static Text di Frame 3 menjadi Password yang anda masukan salah

9. Test Movie dengan menekan Ctrl+Enter 



\section{MEMASUKAN SUARA}

Dalam bab ini diuraikan mengenai:

[1] Memasukan dan Memainkan Suara dalam Macromedia Flash Professional 8

Tutorial di bawah ini akan membahas bagaimana cara memasukan dan memainkan suara di Flash. Anda dapat memilih mau meminkannya di frame atau mau memainkannya dengan menggunakan Actionscript atau mau memainkan suara yang berasal dari swf.

1. Buatlah sebuah flash document kemudian tekan File $>$ Import $>$ Import to Library.

2. Pilih suara yang akan anda import. Format file yang bisa anda masukan adalah WAV (Windows), AIFF (Macintosh), MP3 (Windows/Macintosh), jika anda sudah menginstall Quicktime ver 4 keatas anda bisa mengimport suara yang lain yaitu AIFF (Windows/Macintosh), Sound Designer II (Macintosh), Sound Only QuickTime Movies (Windows/Macintosh), Sun AU (Windows/Macintosh), System 7 Sounds (Macintosh) WAV (Windows/ Macintosh). Setelah anda pilih lalu tekan Open. 
3. Jika anda ingin mengkompresi suara, anda bisa juga bisa melakukannya di flash. Caranya buka panel Library dengan menekan Ctrl+L. Klik kanan suara yang anda import dan pilih Properties.

4. Anda akan berada di panel Sound Properties. Ubah Compression sesuai yang anda inginkan

\section{Memasukan suara ke frame}

1. Klik/seleksi frame pada timeline yang anda ingin beri suara, misalnya anda menginginkannya di frame 1 . Lalu tekan Ctrl+F3 untuk memunculkan panel Properties.

2. Ubah Sound di panel properties ke nama suara yang anda import. Di bawah sound, ada Effect dan Sync yang berfungsi:

\section{Effect}

None : tidak ada efek yang di aktifkan

Left Channel : Suara akan terdengar di speaker sebelah kiri saja

Right Channel : Suara akan terdengar di speaker sebelah kanan saja

Fade Left to Right : Suara akan terdengar dari speaker sebelah kiri ke speaker sebelah kanan

Fade Right to Left : Suara akan terdengar dari speaker sebelah kanan ke speaker sebelah kiri

Fade In : Volume suara akan semakin meningkat secara bertahap selama suara dimainkan.

Fade Out : Volume suara akan semakin menurun secara bertahap selama suara dimainkan. 
Custom : Anda dapat mengatur effect sesuai keinginan anda dengan menggunakan Edit Envelope

\section{Sync}

event : suara akan dimainkan sampai selesai jika jumlah frame adalah 1 atau jumlah frame sama dengan panjang suara

start : suara akan dimainkan sampai selesai

stop : suara tidak akan dimainkan

stream : suara akan dimainkan sesuai dengan jumlah maksimal frame di timeline

Repeat : berapa banyak suara dimainkan

Loop : suara akan dimainkan secara terus menerus

3. Jika sudah selesai mengaturnya tekan Ctrl+Enter untuk melihat hasilnya.

\section{Memainkannya dengan Action script}

1. Tekan Ctrl+L untuk membuka panel Library. Klik kanan suara yang anda import di panel Library dan pilih Linkage...

2. Berikan centang pada Export for ActionScript

3. Ubah Identifier sesuai keinginan anda, misalnya kita ganti menjadi suara1. Jika sudah tekan $\mathrm{OK}$

4. Klik frame 1 dan tekan F9. Pada panel actions yang muncul masukan script berikut: 


\section{MEMBANGUN MULTIMEDIA INTERAKTIF}



5. Tekan Ctrl+Enter untuk melihat hasilnya.

\section{Memainkan suara dari swf}

Caranya sama dengan yang ada dalam tutorial loadMovieNum

\section{A. Membuat yang akan diload}

1. Buatlah sebuah flash document.

2. Tekan Ctrl+R, pada panel yang muncul cari suara yang diinginkan lalu tekan open.

3. Klik frame 1 dan tekan Ctrl+F3. Pada panel properties yang muncul ubah Sound sesuai suara yang anda import tadi.

4. Pilih menu File $>$ Save atau bisa juga menekan $\mathrm{Ctrl}+\mathrm{S}$ pada keyboard. Berikan musik sebagai File Name lalu tekan Save.

5. Test Movie dengan menekan Ctrl+Enter sekaligus akan memunculkan musik.swf pada folder tempat anda menyimpan.

\section{B. Membuat yang akan meload}

1. Buatlah sebuah flash document.

2. Buatlah sebuah static text dengan tulisan LOAD dan buatlah sebuah persegi dengan panjang dan lebar yang sama dengan static text bertuliskan LOAD. Letakkan persegi 
panjang tersebut di tengah-tengah static text bertuliskan LOAD.Seleksi static text dan persegi panjang tersebut kemudian tekan F8.

3. Pada panel yang muncul masukkan load_btn sebagai name dan button sebagai type lalu tekan ok. Seleksi button load_ btn di stage kemudian tekan Ctrl+F3. Pada panel properties yang muncul masukkan load_btn sebagai instance name

4. Buatlah sebuah static text dengan tulisan UNLOAD dan buatlah sebuah persegi dengan panjang dan lebar yang sama dengan static text bertuliskan UNLOAD. Letakkan persegi panjang tersebut di tengah-tengah static text bertuliskan UNLOAD. Seleksi static text dan persegi panjang tersebut kemudian tekan F8.

5. Pada panel yang muncul masukkan unload_btn sebagai name dan button sebagai type lalu tekan ok. Seleksi button unload_btn di stage kemudian tekan Ctrl+F3. Pada panel properties yang muncul masukkan unload_btn sebagai instance name

6. Tempatkan kedua tombol tersebut di bagian tengah-tengah stage.

7. Klik frame 1 dan tekan F9. Pada panel actions yang muncul masukkan script berikut :

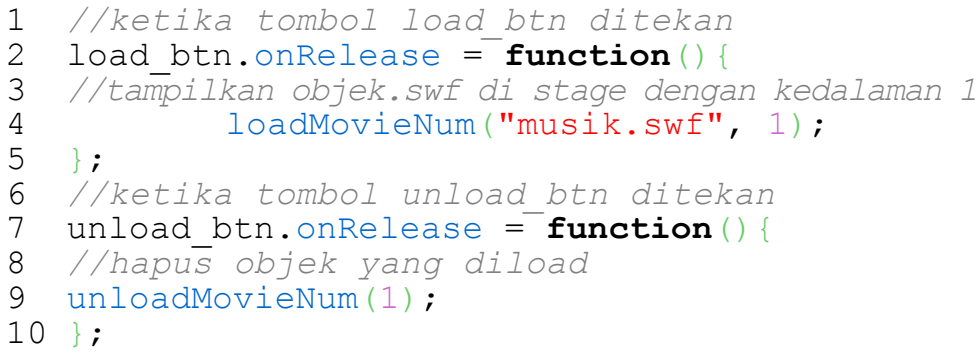


8. Tekan Ctrl+Enter untuk melihat hasilnya.

Untuk mengatur volume suara di flash, kita menggunakan script setVolume. Bagi sebagian pengguna flash yang masih pemula, mereka biasanya hanya mengetahui bahwa setVolume ini digunakan untuk mengatur suara secara keseluruhan (volume pada suara tidak dapat di atur satu per satu). Melalui tutorial ini kami beritahukan bahwa sebenarnya setVolume dapat digunakan untuk mengatur volume suara satu per satu. Caranya dangan memasukan movie clip kosong ke dalam sound objek.

Berikut ini contoh script yang biasa digunakan untuk mengatur seluruh sound :

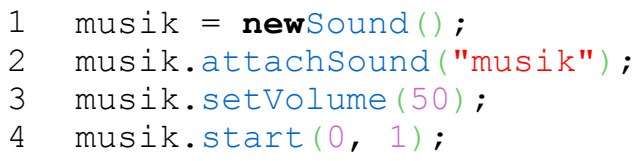

Sedangkan di bawah ini contoh script untuk mengatur sound secara satu per satu :

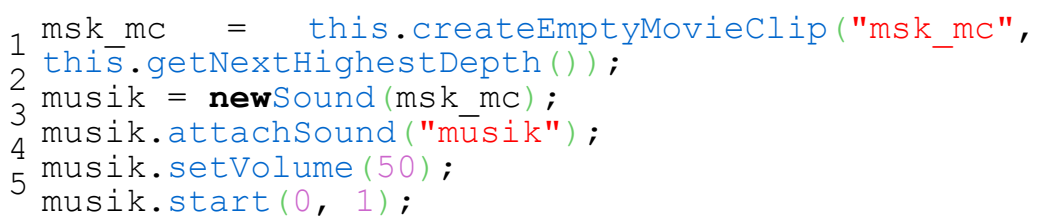

Untuk contoh penggunaanya silahkan lihat di bawah ini :

1. Buatlah sebuah flash document.

2. Pilih menu bar File>Import>Import to Library. Pada panel yang muncul silahkan cari 2 buah suara yang akan digunakan. Kalau bisa suaranya berupa musik.Setelah itu silahkan seleksi kedua buah suara tersebut dan tekan open.

3. Tekan Ctrl+L, pada panel library yang muncul anda akan melihat dua buah suara yang baru saja anda import tadi.

4. Klik kanan suara pertama pada panel library kemudian pilih Linkage. Pada panel yang muncul berikan tanda con- 
treng pada Export for ActionScript lalu masukkan musik1 di dalam kotak identifier lalu tekan ok.

5. Klik kanan suara kedua pada panel library kemudian pilih Linkage. Pada panel yang muncul berikan tanda contreng pada Export for ActionScript lalu masukkan musik2 di dalam kotak identifier lalu tekan ok.

6. Klik frame 1 dan tekan F9. Pada panel actions yang muncul masukkan script berikut : 
1

//membuat movie clip kosong bernama mskl mc pada kedalam paling atas

2 mskl mc = this.createEmptyMovieclip("msk1 mc", this.getNextHighestDepth( ) ) ;

//membuat variable bernama musikl menjadi sound object sekaligus memasukkan movie clip mskl mc ke dalam musikl tersebut

5 musik 1 = newSound ( $\mathrm{msk}_{1}$ mc); //memasukkan suara dari library dengan identifier musikl ke dalam sound object musikl musik1.attachsound ("musik1") ;

//mengatur volume musik1 menjadi 100

musik1.setVolume (100);

//mainkan suara yang ada pada sound object musikl sebanyak 999 kali

musik1.start $(0,999)$;

//membuat movie clip kosong bernama msk2 mc

11 pada kedalam paling atas

msk2_mc = this.createEmptyMovieclip ("msk2 mc", this.getNextHighestDepth ()); sound object sekaligus memasukkan movie clip msk2 mc ke dalam musik2 tersebut

14

15 musik 2 newSound (msk2 mc);

//memasukkan suara dari library dengan

16 identifier musik2 ke dalam sound object musik2 17 musik2 . attachsound ("musik2") ;

18 / /mengatur volume suara pada sound object 19 musik2 menjadi 50

20 musik2. setVolume (50);

21 / mainkan suara yang ada pada sound object

22

23 musik2 sebanyak 999 kali musik2.start $(0,999)$;

7. Tekan Ctrl+Enter untuk melihat hasilnya.

Sebelumnya kita sudah mempelajari memasukkan suara dan menghentikan suara, selanjutnya kita akan mempelajari bagaimana membuat suara dapat berhenti apabila tombol pause ditekan dan memainkannya kembali apabila tombol play 
ditekan. Biasanya kami menggunakan suara rel kereta api seperti pada tutorial sound slider tetapi agar para pembaca tidak kaget kami menggunakan musik loop dalam tutorial ini

1. Buatlah sebuah flash document.

2. Buatlah sebuah objek seperti gambar di bawah ini :

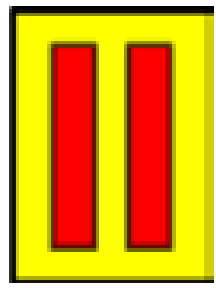

3. Seleksi objek tersebut dan tekan F8. Pada panel yang muncul masukkan pause_btn sebagai name dan button sebagai type lalu tekan ok.

4. Seleksi button pause_btn di stage kemudian tekan Ctrl+F3. Pada panel properties yang muncul masukkan pause_btn di dalam kotak instance name.

5. Buatlah objek seperti gambar di bawah ini :

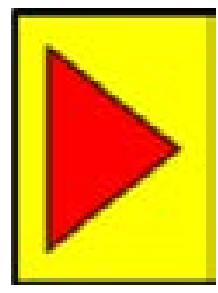

6. Seleksi objek tersebut dan tekan F8. Pada panel yang muncul masukkan play_btn sebagai name dan button sebagai type lalu tekan ok.

7. Seleksi button pause_btn di stage kemudian tekan Ctrl+F3. Pada panel properties yang muncul masukkan play_btn di dalam kotak instance name. 
8. Tekan $\mathrm{Ctrl}+\mathrm{R}$, pada panel yang muncul cari suara yang diinginkan kemudian tekan open.

9. Tekan $\mathrm{Ctrl}+\mathrm{L}$, pada panel library yang muncul klik kanan suara yang baru di import kemudian pilih Linkage. Pada panel yang muncul berikan tanda contreng pada Export for ActionScript dan masukkan musik di dalam kotak identifier lalu tekan ok.

10. Klik frame 1 dan tekan F9. Pada panel actions yang muncul masukkan script berikut :

1 //membuat variable bernama Pause dengan nilai false

2 Pause $=$ false;

3 //membuat fungsi bernama mainkanMusik

4 function mainkanMusik()

//membuat variable musik sebagai sound object musik.attachsound ("bom");

//mainkan suara di dalam variable musik sebanyak 999 kali

10 musik.start $(0,999)$;

11

$12 / / j i k a$ tombol pause btn ditekan

13 pause_btn.onPress = function

14 - //membuat variable posisi dengan nilai pembualatan ke bawah dari posisi terakhir suara pada variable 
15 musik yang dibagi 1000

16 posisi

17 Math.floor (musik.position/1000);

18 //hentikan suara pada variable musik

19 musik.stop ();

20 //ubah nilai variable Pause menjadi true

21 Pause = true;

$22\} ;$

23 //jika tombol play btn ditekan

24 play_btn.onPress = function ()

25 //jika variable Pause bernilai true 26 if (Pause) \{

27 //mainkan suara di dalam variable musik sesuai nilai variable posisi sebanyak 1 kali

28 musik.start (posisi, 1);

29 //ubah nilai variable Pause menjadi false l/jika suara di dalam variable musik selesai dimainkan musik.onsoundComplete = function()

mainkanMusik

35

mainkanMusik();

36

$37\} ;$

$38 / / m e n j a l a n k a n$ fungsi mainkanMusik ketika swf pertama kali dijalankan

39 mainkanMusik ();

11. Tekan Ctrl+Enter untuk melihat hasilnya. Tutorial berikut ini digunakan sebagai pelengkap tutorial 
Pause dan Play Suara. Pada tutorial kali ini kita akan membahas tentang bagaimana cara menghentikan suara yang sedang dimainkan. Sebenarnya pada script Pause dan Play Suara sudah ada.Tapi karena digunakan dalam tombol pause, mungkin ada yang belum tahu.

Untuk menghentikan suara kita cukup menuliskan stop() pada variable yang menampung suara yang sedang dimainkan. Misalnya : suara ditampung pada variable Musicz, maka untuk menghentikannya kita menuliskan Musicz.stop()

Untuk contoh lainnya, kita akan menggabungkannya dengan tutorial Pause dan Play Suara :

1. Bukalah fla dari source Pause dan Play Suara.

2. Buatlah sebuah objek seperti gambar dibawah ini :

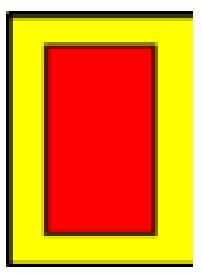

3. Seleksi objek tersebut dan tekan F8. Pada panel yang muncul masukan stop_btn sebagai name dan button sebagai type lalu tekan ok.

4. Letakan seluruh obiek di stage meniadi senerti ini :
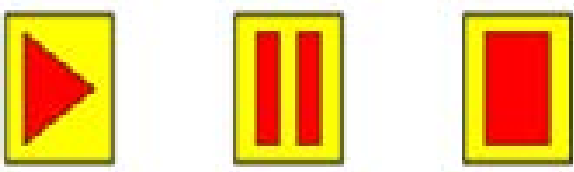

5. Klik frame 1 dan tekan F9. Pada panel actions yang muncul ubah seluruh scriptnya menjadi seperti ini : 


\section{MEMASUKAN SUARA}

1 //membuat variable bernama Pause dengan nilai false

2 Pause = false;

3 //membuat variable bernama stop dengan nilai false

4 Stop = false;

5 //membuat fungsi bernama mainkanMusik

6 function mainkanMusik()

7 //membuat variable musik sebagai sound object musik = newSound ();

9

//masukkan suara berlinkage bgm dari panel library ke dalam variable musik 10 musik.attachsound ("bogm") ;

11 //mainkan suara di dalam variable musik sebanyak 999 kali

12 musik.start $(0,999)$;

13

14 //jika tombol pause btn ditekan 15 pause_btn.onPress = function ()\{

16 //membuat variable posisi dengan nilai pembualatan ke bawah dari posisi terakhir suara pada variable musik yang dibagi 1000

17 posisi

18 Math.floor (musik.position/1000);

19 //hentikan suara pada variable musik

20 musik.stop();

21 / /ubah nilai variable Pause menjadi true

22 Pause = true;

$23\} ;$

24 / /jika tombol play btn ditekan

25 play_btn.onPress = function ()

26 //jika variable stop bernilai true

27 if (Stop)

28 //mainkan suara di dalam variable musik sebanyak 999 kali 
menjadi false

menjadi true false

$$
\text { Stop = false; }
$$

l/jika variable Pause bernilai true dan variable stop bernilai false

variable musik sesuai nilai variable posisi sebanyak 1 kali

menjadi false

$$
\text { Pause = false; }
$$

41

\section{musik selesai dimainkan}

$48 / / j i k a$ tombol stop btn ditekan

49 stop_btn.onPress = function ( ) \{

$50 / / u b a h$ nilai variable stop menjadi true

$$
\text { Stop = true; }
$$

52 /hentikan suara pada variable musik

53 musik.stop ();

$54\}$;

$55 / / m e n j a l a n k a n$ fungsi mainkanMusik ketika swf pertama kali dijalankan mainkanMusik();

\section{Tekan Ctrl+Enter untuk melihat hasilnya.}




\section{FSCOOMMAND}

Dalam bab ini diuraikan mengenai:

[1]Membuat Tampilan Fullscreen dalam Macromedia Flash Professional 8

[2]Membuat Tampilan Minimize dalam Macromedia Flash Professional 8.

[3]Membuat Tombol Keluar dalam Macromedia Flash Professional 8.

Kali ini kita akan mempelajari cara menggunakan fscommand. Ada 6 jenisnya tapi kita hanya akan mempelajari 5 jenis saja.

1. fscommand fullscreen

Kegunaan : membuat flash movie/swf yang dimainkan menjadi fullscreen jika nilainya true. Bagi anda yang menginginkan flash movie/swf tampil fullscreen anda bisa menggunakan fscommand ini. Penulisannya:

1 fscommand("fullscreen", "true");

2. fscommand allowscale

Kegunaan : Ukuran konten di dalam swf tidak akan berubah walaupun ukuran window swf diperbesar jika 
nilainya false. Penulisannya :

1 fscommand("allowscale", "false");

3. fscommand showmenu

Kegunaan : menghilangkan menu File, View, Control, Help dan jika swf diklik kanan maka hanya muncul settings dan about jika nilainya true. Kelemahannya, di swf akan sedikit muncul ruang kosong di bagian atas dan bawah / konten akan terlihat sedikit mengecil. Penulisannya :

1 fscommand ("showmenu", "false");

4. fscommand trapallkeys

Kegunaan : membuat pengguna tidak bisa menggunakan keyboard di swf yang dimainkan jika nilainya true. Keyboard hanya bisa digunakan dengan actionscript key (contohnya : if (Key.isDown(Key.BACKSPACE)) \{\} ). Penulisannya :

1 fscommand("trapallkeys", "true");

5. fscommand quit

Kegunaan : menutup swf yang dimainkan. Tidak ada nilainya. Penulisannya:

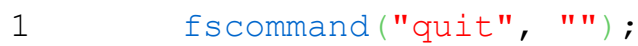

Kelimanya dapat digunakan secara bersama-sama. Lihatlah nilai (true/false) masing-masing sesuai keterangan di atas. Jika nilainya berupa kebalikannya (misalnya true diubah menjadi false) maka kegunaannya adalah kebalikan dari kegunaan yang ditulis di atas. Untuk mengetesnya apakah berjalan atau tidak, anda harus memainkan swf-nya langsung (klik 2 kali swf yang akan dimainkan di Windows Explorer). Anda tidak dapat mengetesnya melalui Test Movie.

Stop All Sounds digunakan untuk menghentikan seluruh musik/suara yang sedang dimainkan. Penulisannya : 
Sebelumnya sebaiknya anda membaca terlebih dahulu artikel memasukkan suara karena kita menggunakannya sebagai contoh penggunaan stopAllSounds.

1. Buatlah sebuah flash document.

2. Lalu tekan Ctrl+R. Pada panel yang muncul cari musik/ suara yang diinginkan lalu tekan Open.

3. Jika sudah tekan Ctrl+L. Pada panel library yang muncul klik kanan musik/suara yang anda masukan lalu pilih linkage.

4. Pada panel linkage properties yang muncul berikan tanda contreng/centang pada Export for ActionScript dan masukan musik pada Identifier lalu tekan ok.

5. Buatlah sebuah button di stage. Seleksi button tersebut dan tekan Ctrl+F3.Pada panel properties yang muncul masukkan tombol di kotak instance name.

6. Klik frame 1 dan tekan F9. Pada panel actions yang muncul masukkan script berikut :

1 //mySound adalah sebuah variable, anda dapat menggantinya sesuai keinginan anda misalnya suaraku

2 mySound = newSound ();

3 //suaral adalah Identifier yang anda berikan di Linkage

4 mysound.attachsound("musik");

5 //masukan script di bawah untuk memainkan suaranya

6 /langka 999 di bawah ini menunjukan berapa banyak suara dimainkan

7 mysound.start (0, 999);

8 //ketika tombol ditekan

9 tombol.onPress $=$ function

10 //hentikan semua suara

11 stopallsounds();

$12\}$;

7. Tekan Ctrl+Enter untuk melihat hasilnya. 
1. Buatlah sebuah flash document.

2. Buatlah persegi panjang berwarna merah bergaris hitam. Buatlah sebuah static text bertuliskan tombol dan tempatkan di tengah-tengah persegi panjang. Seleksi persegi panjang dan static text lalu tekan F8. Pada panel yang muncul masukkan tombol sebagai name dan button sebagai type lalu tekan ok.

3. Seleksi tombol dan tekan Ctrl+F3. Pada panel properties yang muncul masukkan tombol sebagai instance name.

4. Tekan Ctrl+R. Pada panel yang muncul cari 2 buah suara yang diinginkan dan tekan open.

5. Tekan F11 untuk memunculkan panel library.

6. Klik kanan suara yang akan digunakan sebagai suara saat mouse berada di atas tombol dan pilih Linkage. Pada panel yang muncul berikan tanda contreng/centang pada Export for ActionScript dan masukkan over sebagai identifier.

7. Klik kanan suara yang akan digunakan sebagai suara saat tombol ditekan dan pilih Linkage. Pada panel yang muncul berikan tanda contreng/centang pada Export for ActionScript dan masukkan click sebagai identifier.

8. Klik frame 1 dan tekan F9. Pada panel actions yang muncul masukkan script berikut : 
$1 / / m e m b u a t$ variable atas berisi suara berlinkage over

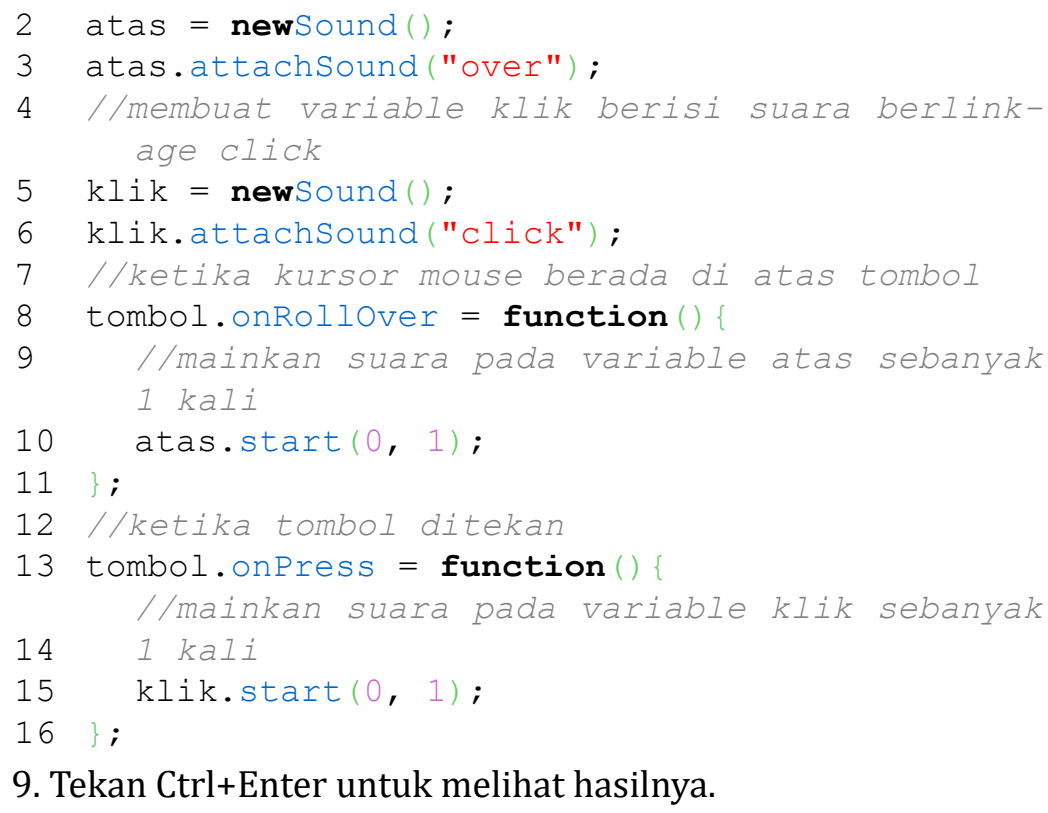





\section{LOAD MOVIE}

Dalam bab ini diuraikan mengenai:

[1]Memasukan file berformat swf, jpeg, gif dan png kedalam Macromedia Flash Professional 8

LoadMovieNum adalah script yang digunakan untuk menampilkan file berformat swf, jpeg, gif, dan png ke dalam sebuah swf dengan level kedalaman (depth) yang dapat diatur. Penulisannya :

\section{loadMovieNum(url, depth);}

url : tempat anda menyimpan file yang akan diload. Jika masih dalam satu folder dengan swf yang meload maka anda cukup menuliskan nama beserta ekstensinya, contohnya "namafile. swf". Jika tidak dalam satu folder anda harus menuliskan alamat lengkapnya, contohnya "C:/Folder/namafile.swf" Depth : level kedalaman tempat objek ditampilkan di stage Contoh penggunaannya :

\section{A. Membuat yang akan diload}

1. Buatlah sebuah flash document.

2. Buatlah sebuah lingkaran dan beri warna biru dengan garis hitam. 
3. Klik kanan frame 2 dan pilih Insert Keyframe

4. Ubah warna lingkaran pada frame 2 menjadi berwarna merah.

5. Pilih menu File $>$ Save atau bisa juga menekan Ctrl+S pada keyboard. Berikan objek sebagai File Name lalu tekan Save.

6. Test Movie dengan menekan Ctrl+Enter sekaligus akan memunculkan objek.swf pada folder tempat anda menyimpan.

\section{B. Membuat yang akan meload}

1. Buatlah sebuah flash document.

2. Buatlah sebuah static text dengan tulisan LOAD dan buatlah sebuah persegi dengan panjang dan lebar yang sama dengan static text bertuliskan LOAD. Letakkan persegi panjang tersebut di tengah-tengah static text bertuliskan LOAD.Seleksi static text dan persegi panjang tersebut kemudian tekan F8.

3. Pada panel yang muncul masukkan load_btn sebagai name dan button sebagai type lalu tekan ok. Seleksi button load_btn di stage kemudian tekan Ctrl+F3. Pada panel properties yang muncul masukkan load_btn sebagai instance name

4. Buatlah sebuah static text dengan tulisan UNLOAD dan buatlah sebuah persegi dengan panjang dan lebar yang sama dengan static text bertuliskan UNLOAD. Letakkan persegi panjang tersebut di tengah-tengah static text bertuliskan UNLOAD. Seleksi static text dan persegi panjang tersebut kemudian tekan F8.

5. Pada panel yang muncul masukkan unload_btn sebagai name dan button sebagai type lalu tekan ok. Seleksi but- 
ton unload_btn di stage kemudian tekan Ctrl+F3. Pada panel properties yang muncul masukkan unload_btn sebagai instance name

6. Tempatkan kedua tombol tersebut di bagian atas stage.

7. Klik frame 1 dan tekan F9. Pada panel actions yang muncul masukkan script berikut :

1 //ketika tombol load btn ditekan

2 load_btn.onRelease = function ( )

3 //tampilkan objek.swf di stage dengan kedalaman 1

4 loadMovienum("objek.swf", 1);

$5\}$;

6 //ketika tombol unload btn ditekan

7 unload_btn.onRelease = function()

8 //hapus objek hasil loadMovie

9 unloadMovieNum(1);

$10\}$;

8. Tekan Ctrl+Enter untuk melihat hasilnya. 



\section{MEMBUAT \\ KALENDER}

Dalam bab ini diuraikan mengenai:

[1]Menampilkan kalender dalam Macromedia Flash Professional 8

Kalender memang sudah ada dan bisa dilihat di masing-masing komputer dan rugi rasanya jika membuatnya.Hal ini tidak sepenuhnya benar. Jika anda membuat sebuah aplikasi dengan Flash dan anda membuatnya Fullscreen maka otomatis anda tidak dapat melihat jam begitu juga kalender yang ada di komputer. Oleh sebab itu di sinilah fungsi kita membuat kalender. Di bawah ini cara membuatnya :

1. Buatlah 4 buah Dynamic Text dengan masing-masing Var : hari, tanggal, bulan, tahun.

2. Ubah ukuran Dynamic Text sesuai panjang jumlah maksimal karakter yang akan dimuat.

3. Klik Frame 1 lalu tekan F9 dan masukan script berikut : 


\section{MEMBANGUN MULTIMEDIA INTERAKTIF}

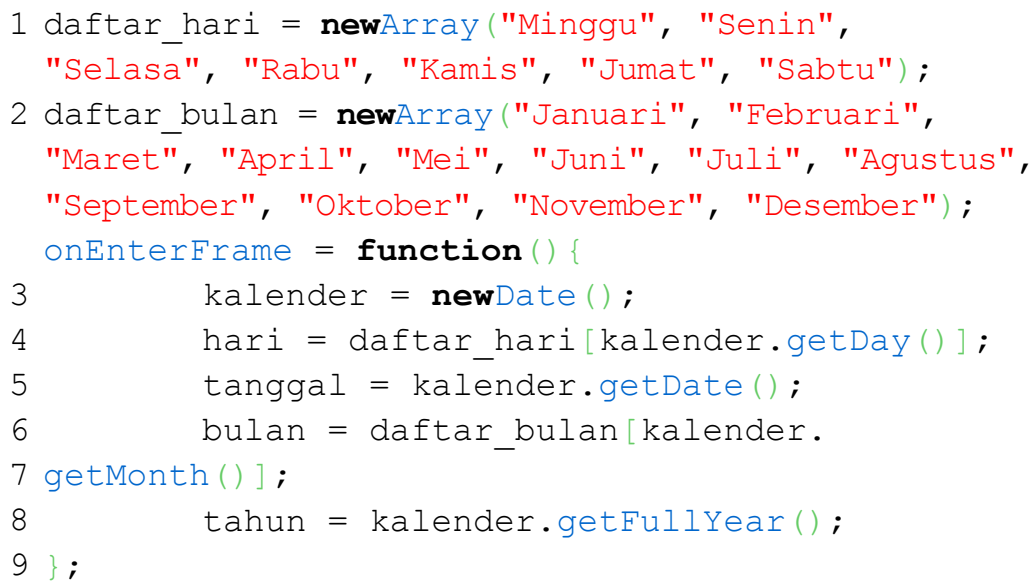

4. Terakhir Test Movie dengan menekan Ctrl+Enter pada keyboard.

Setelah membuat kalender, tentu kurang lengkap rasanya jika kita tidak membuat jam. Kali ini kita akan membuat jam digital dengan sistem 24 jam. Berikut tutorialnya :

1. Buatlah 3 buah Dynamic Text dengan masing-masing Var : jam, menit, detik

2. Buatlah 2 buah Static Text dan berikan tanda : sebagi tulisannya

3. Ubah ukuran Static Text dan Dynamic Text sesuai panjang jumlah maksimal karakter yang akan dimuat dan atur letaknya.

4. Klik Frame 1 lalu tekan F9 dan masukan script berikut : 


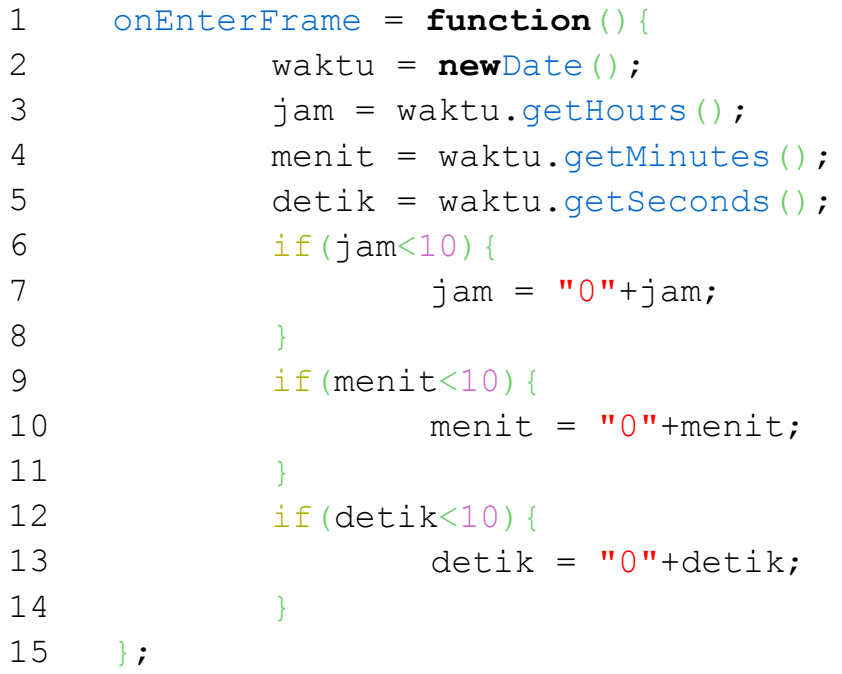

5. Terakhir Test Movie dengan menekan Ctrl+Enter pada keyboard. 



\section{MEMBUAT SOAL PILIHAN GANDA}

Dalam bab ini diuraikan mengenai:

[1]Membuat Soal Pilihan Ganda Macromedia Flash Professional 8

Selain soal essay kita juga dapat membuat soal pilihan ganda (a, b, c, d). Pada tutorial kali ini kita akan membuat soal pilihan ganda. Di bawah ini kami hanya menjelaskan bagaimana cara membuatnya hanya dengan satu soal saja. Hal ini dikarenakan jika kami membuatnya lebih dari 1 soal maka tutorialnya akan panjang sekali dan juga tutorialnya akan berulang-ulang karena cara membuat soal yang satu dengan soal yang lain hampir sama. Tapi kami juga memberikan hasil jadinya (.fla) dengan 3 soal yang dapat di download pada source tutorial ini.

1. Buatlah 5 buah Static Text dan masing-masing diberi tulisan berikut:

1. Tempat sarapan tutorial flash adalah ...

a. Warung Makan

b. Warung Tegal 
c. Warung Flash

d. Warung Pojok

2. Tempatkan 5 buah Static Text tadi seperti gambar di bawah ini :

\section{Tempat sarapan tutorial flash adalah ...}
a. Warung Makan
b. Warung Tegal
c. Warung Flash
d. Warung Pojok

3. Pastikan anda tidak menyeleksi satu objek pun di stage, lalu tekan Ctrl+F8 maka kotak dialog Create new Symbol akan muncul. Berikan invs_btn sebagai Name dan ubah Type-nya menjadi Button lalu tekan OK

4. Anda akan masuk ke stage invs_btn. Klik frame Hit yang terletak di Timeline lalu tekan F7. Gambarlah sebuah persegi panjang dengan panjang dan lebar yang cukup untuk menutupi jawaban abcd di atas.

5. Tekan Ctrl+E anda akan berada di Stage Scene 1. Buka Library dengan menekan Ctrl+L. Drag invs_btn di Library ke stage hingga jumlahnya 4 buah.

6. Tempatkan 4 buah invs_btn tadi ke masing-masing jawaban abcd. Buatlah titik Registration berada di tengah-tengah huruf abcd seperti gambar di bawah ini :

\section{Tempat sarapan tutorial flash adalah ...}
a. Warung Makan
b. Warung Tegal
c. Warung Flash
d. Warung Pojok 
7. Klik 2 kali salah satu invs_btn di stage. Ubah letak persegi panjang sampai dapat menutupi jawaban seperti gambar di bawah ini :

\section{Tempat sarapan tutorial flash adalah ...}

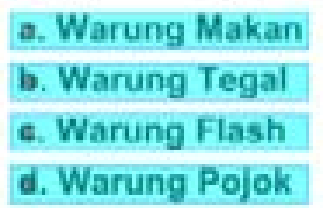

8. Tekan Ctrl+E untuk kembali ke stage Scene 1. Berikan Instance Name berikut pada masing-masing invs_btn secara berurutan dari atas sampai ke bawah : tombol1a, tombol1b, tombol1c, tombol1d

9. Klik tombol1a lalu tekan F9 dan masukan script berikut :

1 //ketika tekanan mouse dilepaskan setelah ditekan

2 on (release)

3 //jika tulis bernilai true

4

if(tulis)

//posisi $x$ silangl sama dengan posisi $x$ tombol 5 ini

6 silangl._x = tombolla._x;

//posisi y silangl sama dengan posisi y tombol 7 ini

8 silangl._y = tombolla._y;

9 //nilai jawabanl diubah menjadi false

jawaban1 = false;

10. Klik tombol1b lalu tekan F9 dan masukan script berikut : 


\section{MEMBANGUN MULTIMEDIA INTERAKTIF}

1 //ketika tekanan mouse dilepaskan setelah ditekan

2 on (release)

3

4

/ jika tulis bernilai true if (tulis)

/lposisi x silangl sama dengan posisi x tombol 5 ini

6

silang1. $\mathrm{x}=$ tombol1b. $\mathrm{x}$;

//posisi y silangl sama dengan posisi y tombol

7 ini

8

9

10

11

12

11. Klik tombol1c lalu tekan F9 dan masukan script berikut :

1 //ketika tekanan mouse dilepaskan setlah ditekan

2 on (release)

3

4

/ljika tulis bernilai true

if(tulis)

/ posisi x silangl sama dengan posisi x tombol

5 ini

6

silang1. $\mathrm{x}=$ tombollc. $\mathrm{x}$;

/ posisi y silangl sama dengan posisi y tombol

7 ini

8 silangl. $y=$ tombollc. $y$;

9 //nilai jawabanl diubah menjadi true

10

jawaban1 = true;

11

12

12. Klik tombol1d lalu tekan F9 dan masukan script berikut : 
1 //ketika tekanan mouse dilepaskan setelah ditekan

2 on (release)

//jika tulis bernilai true

5

if (tulis)

//posisi $x$ silangl sama dengan posisi $x$ tombol ini

$$
\text { silang1._x = tombolld._x; }
$$

//posisi y silangl sama dengan posisi y tombol ini

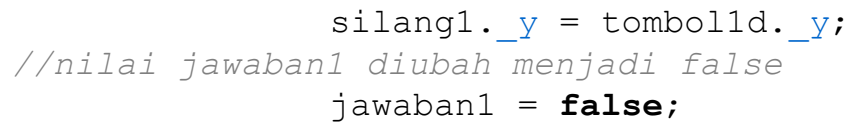

13. Buatlah sebuah garis silang dengan luas yang dapat menutupi huruf a, b, c, d. Klik garis tersebut dan tekan F8. Pada kotak dialog yang muncul berikan silang sebagai Name dan Movie clip sebagai Type lalu tekan OK.

14. Klik Movie clip silang tadi dan berikan silang1 sebagai Instance Name

15. Buatlah sebuah garis lingkaran dengan diameter yang dapat menutupi huruf a, b, c, d. Klik garis tersebut dan tekan F8. Pada kotak dialog yang muncul berikan lingkaran sebagai Name dan Movie clip sebagai Type lalu tekan OK.

16. Klik Movie clip lingkaran tadi dan berikan lingkaran1 sebagai Instance Name. Letakan Movie clip lingkaran1 huruf (a/b/c/d) jawaban yang benar dengan titik Registration berada tepat di tengah-tengah huruf. 


\section{Tempat sarapan tutorial flash ac}

a. Warung Makan

b. Warung Tegal

(c.)Warung Flash

d. Warung Pojok

17. Pastikan anda masih menyeleksi Movie clip lingkaran1, lalu buka panel Properties (Ctrl+F3) dan ubah Colornya menjadi Alpha dengan nilai $0 \%$

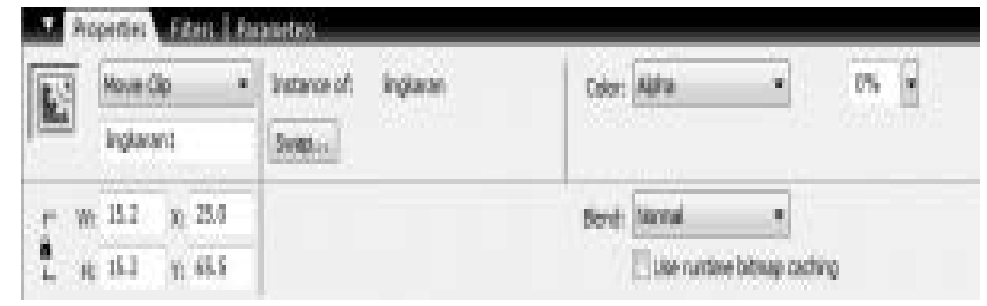

18. Buatlah Static Text bertuliskan Koreksi. Gambarlah persegi panjang dan tempatkan di tengah-tengah Static Text Koreksi.

19. Seleksi Static Text koreksi dan persegi panjang tadi lalu tekan F8. Berikan koreksi_btn sebagai Name dan pilih Button sebagai Typenya lalu tekan ok.

20. Klik koreksi_btn lalu tekan F9 dan berikan script berikut : 
//ketika tekanan mouse dilepaskan setelah ditekan on (release)

//jika cek bernilai true

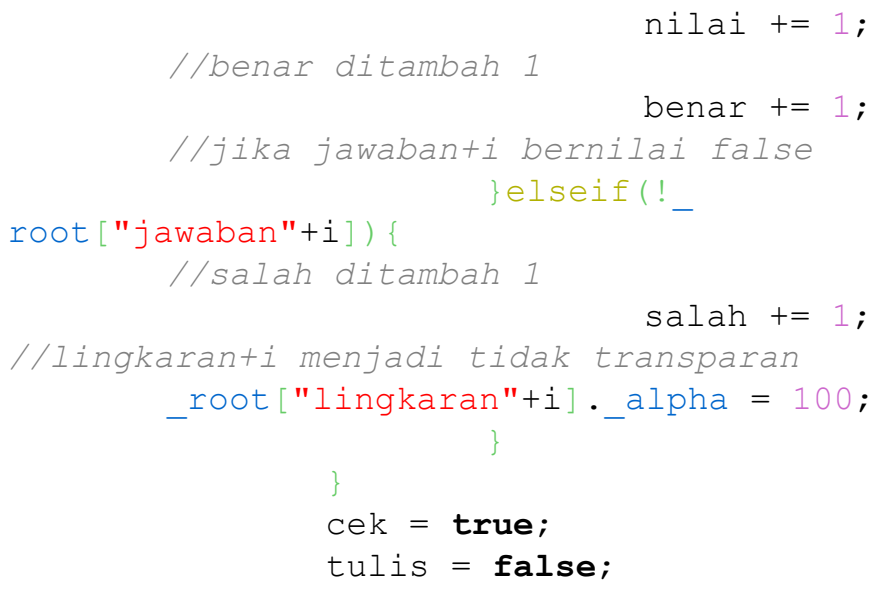

21. Buatlah Static Text bertuliskan Reset. Gambarlah persegi panjang dan tempatkan di tengah-tengah Static Text Reset.

22. Seleksi Static Text Reset dan persegi panjang tadi lalu tekan F8. Berikan reset_btn sebagai Name dan pilih Button sebagai Typenya lalu tekan ok.

23. Klik reset_btn lalu tekan F9 dan berikan script berikut :

1 //ketika tekanan mouse dilepaskan setelah ditekan

2 on (release) 
24. Buatlah 3 buah Static Text dan beri masing-masing tulisan berikut Benar: , Salah: , Nilai:

25. Buatlah 3 buah Dynamic Text dengan masing-masing Var benar, salah, nilai. Lalu tempatkan koreksi_btn, reset_btn, 3 buah Static Text dan Dynamic Text tadi seperti gambar di bawah ini :

\section{Koreksi}

Benar
Salah

Nilai :

\section{Letak tombol dan text}

26. Klik frame 1 pada Timeline Scene 1 dan tekan F9. Pada kotak Action masukan script berikut :
1

4

5

6

7

8

9

10

11

12

13

14

15

16

17

18

19 //fungsi reset dijalankan sekali ketika frame ini dimainkan

20 reset ();

function reset

//membuat variable $i=1$

for $(i=1 ; i<2 ; i++)$

//posisi $x$ movie clip silangti $=-100$

root ["silang"+i]. $x=-100$;

//posisi y movie clip silangti $=-100$

_root["silang"+i]._y $=-100$;

//jawabanti bernilai dengan false root ["jawaban"+i] = false;

lingkaranti transparan

root ["lingkaran"+i]. alpha $=0$;

cek = false;

tulis = true;

nilai $=0$;

benar $=0$;

salah $=0$;

\section{Reset}

27. Tekan Ctrl+Enter untuk melihat hasilnya. 
Selanjutnya kita akan mengembangkan teknik pembuatan soal pilihan ganda. Di dalam soal pilihan ganda 2 ini soal-soal akan kita masukkan di dalam salah satu component yaitu scrollpane. Scrollpane ini digunakan agar soal dapat di scroll. Dalam tutorial di bawah ini kami hanya menggunakan 2 soal saja karena akan sangat panjang tutorialnya jika soalnya banyak sedangkan cara membuatnya hampir sama satu sama lain.

\section{Membuat soal pertama}

1. Buatlah 5 buah Static Text dan masing-masing diberi tulisan berikut:

1. Tempat sarapan tutorial flash adalah ...

a. Warung Makan

b. Warung Tegal

c. Warung Flash

d. Warung Pojok

2. Tempatkan 5 buah Static Text tadi seperti gambar di bawah ini :

\section{Tempat sarapan tutorial flash adalah ...}
a. Warung Makan
b. Warung Tegal
c. Warung Flash
d. Warung Pojok

\section{Membuat soal kedua}

3. Buatlah 5 buah Static Text dan masing-masing diberi tulisan berikut:

2. Dibawah ini yang tidak termasuk dalam Text Tool adalah ...

a. Static Text

b. Dynamic Text 
c. Input Text

d. Texture

4. Tempatkan 5 buah Static Text tadi seperti gambar di bawah ini :

1. Tempat sarapan tutorial flash adalah ...
a. Warung Makan
b. Warung Tegal
c. Warung Flash
d. Warung Pojok

2. Dibawah ini yang tidak termasuk dalam Text Tool adalah .
a. Static Text
b. Dynamic Text
c. Input Text
d. Texture

5. Pastikan anda tidak menyeleksi satu objek pun di stage, lalu tekan Ctrl+F8 maka kotak dialog Create new Symbol akan muncul. Berikan invs_btn sebagai Name dan ubah Type-nya menjadi Button lalu tekan OK

6. Anda akan masuk ke stage invs_btn. Klik frame Hit yang terletak di Timeline lalu tekan F7. Gambarlah sebuah persegi panjang dengan panjang dan lebar yang cukup untuk menutupi jawaban abcd di atas.

7. Tekan Ctrl+E anda akan berada di Stage Scene 1. Buka Library dengan menekan Ctrl+L. Drag invs_btn di Library ke stage hingga jumlahnya 8 buah.Tempatkan 8 buah invs_btn tadi ke masing-masing jawaban abcd. Buatlah titik Registration berada di tengah-tengah huruf abcd seperti gambar di bawah ini : 
1. Tempat sarapan tutorial flash adalah ...
D. Warung Makan
b. Warung Tegal
a. Warung Flash
6. Warung Pejok

2. Dibawah ini yang tidak termasuk dalam Text Tool adalah ..-

\section{Static Text}

b. Dynamic Text

a. Input Toxt

d. Texture

8. Klik 2 kali salah satu invs_bth di stage. Ubah letak persegi panjang sampai dapat menutupi jawaban seperti gambar di bawah ini :

1. Tempat sarapan tutorial flash adalah ...
E. Warung Makan
b. Warung Tegal
c. Warung Flash
c. Warung Pojok

2. Dibawah ini yang tidak termasuk dalam Text Tool adalah ...
5. Static Text
b. Dynamic Text
e. Input Text
d. Texture

9. Tekan Ctrl+E untuk kembali ke stage Scene 1. Berikan Instance Name berikut pada masing-masing invs_btn secara berurutan dari atas sampai ke bawah : tombol1a, tombol1b, tombol1c, tombol1d, tombol2a, tombol2b, tombol2c, tombol2d

10. Klik tombol 1a lalu tekan F9 dan masukan script berikut : 


\section{MEMBANGUN MULTIMEDIA INTERAKTIF}

1 //ketika tekanan mouse dilepaskan setelah ditekan

2 on (release)

3 / /jika variable tulis bernilai true

4

//posisi x movie clip silangl sama dengan posisi

$5 \times$ movie clip tombol ini

$6 \quad$ silangl._x $=$ tombolla._x;

7 / /posisi y movie clip silangl sama dengan posisi y movie clip tombol ini

9 //movie clip silangl menjadi tidak transparan

11. Klik tombol1b lalu tekan F9 dan masukan script berikut :

1 //ketika tekanan mouse dilepaskan setelah ditekan

2 on (release)

3 / /jika variable tulis bernilai true

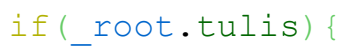

//posisi x movie clip silangl sama dengan posisi

5 x movie clip tombol ini

6

$$
\text { silang1._x = tombollb._x; }
$$

/ posisi y movie clip silangl sama dengan posisi

7 y movie clip tombol ini

8

silang1._y = tombollb._y;

9 //movie clip silangl menjadi tidak transparan

12. Klik tombol1c lalu tekan F9 dan masukan script berikut : 
1 //ketika tekanan mouse dilepaskan setelah ditekan

2 on (release)

3 //jika variable tulis bernilai true 4 if(_root.tulis) \{

5 //posisi x movie clip silangl sama dengan posisi $x$ movie clip tombol ini

7 //posisi y movie clip silangl sama dengan posisi y movie clip tombol ini

9 //movie clip silangl menjadi tidak transparan

$11 / / n i l a i$ variable jawaban diubah menjadi true

13. Klik tombol1d lalu tekan F9 dan masukan script berikut :

1 //ketika tekanan mouse dilepaskan setelah ditekan 2 on (release) \{

3 /ljika variable tulis bernilai true

4 if(_root.tulis)

5 //posisi x movie clip silangl sama dengan posisi $x$ movie clip tombol ini

7 //posisi y movie clip silangl sama dengan posisi y movie clip tombol ini

9 //movie clip silangl menjadi tidak transparan

$11 / / n i l a i$ variable jawaban diubah menjadi false

14. Klik tombol2a lalu tekan F9 dan masukan script berikut : 


\section{MEMBANGUN MULTIMEDIA INTERAKTIF}

1 //ketika tekanan mouse dilepaskan setelah ditekan

2 on (release)

3 / /jika variable tulis bernilai true

if(_root.tulis) \{

/ posisi x movie clip silangl sama dengan posisi

$5 \times$ movie clip tombol ini

6

silang2._x = tombol2a._x;

/ / posisi y movie clip silangl sama dengan posisi

7 y movie clip tombol ini

8

9

10

11

12

13

14

15. Klik tombol2b lalu tekan F9 dan masukan script berikut :

1

//ketika tekanan mouse dilepaskan setelah ditekan on (release)

/ Jika variable tulis bernilai true

if(_root.tulis) \{

/ posisi x movie clip silangl sama dengan posisi $x$ movie clip tombol ini

silang2. $\mathrm{x}=$ tombol2b. $\mathrm{x}$;

9 /posisi y movie clip silangl sama dengan posisi y movie clip tombol ini

silang2._y = tombol2b._y;

9 //movie clip silangl menjadi tidak transparan silang2._alpha $=100$;

11 / / nilai variable jawabañ diubah menjadi false root.jawaban2 = false;

13

14

16. Klik tombol2c lalu tekan F9 dan masukan script berikut : 
17. Klik tombol2d lalu tekan F9 dan masukan script berikut :

\section{2}

3

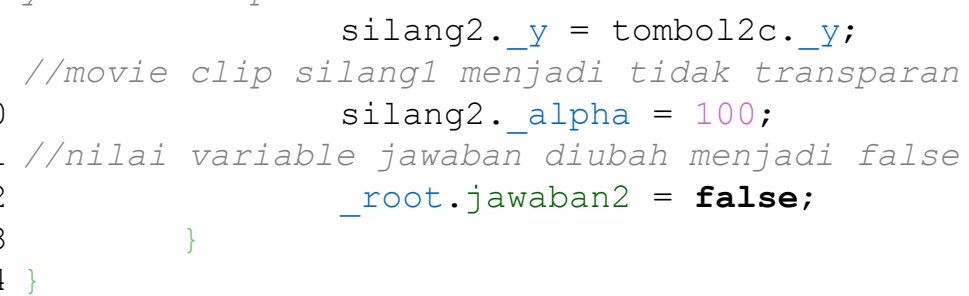

18. Buatlah sebuah garis silang dengan luas yang dapat menutupi huruf a, b, c, d. Klik garis tersebut dan tekan F8. Pada kotak dialog yang muncul berikan silang sebagai Name dan Movie clip sebagai Type lalu tekan OK. 
19. Seleksi movie clip silang tadi dan tekan Ctrl+D sekali untuk memunculkan satu movie clip silang lagi. Seleksi movie clip silang yang pertama lalu tekan Ctrl+F3. Pada panel properties yang muncul masukkan silang1 dalam kotak instance name.Seleksi movie clip silang yang kedua lalu masukkan silang2 dalam kotak instance name di panel properties (tekan Ctrl+F3 jika belum muncul)

20. Buatlah sebuah garis lingkaran dengan diameter yang dapat menutupi huruf a, b, c, d. Klik garis tersebut dan tekan F8. Pada kotak dialog yang muncul berikan lingkaran sebagai Name dan Movie clip sebagai Type lalu tekan OK.

21. Seleksi movie clip lingkaran dan tekan Ctrl+D untuk memunculkan movie clip lingkaran yang kedua. Seleksi movie clip lingkaran yang pertama dan masukkan lingkaran1 di kotak instance name pada panel properties. Seleksi movie clip lingkaran yang kedua dan masukkan lingkaran2 di kotak instance name pada panel properties.

22. Letakan movie clip lingkaran1 di jawaban c soal pertama dan letakan movie clip lingkaran2 di jawaban d soal kedua. Seleksi movie clip lingkaran1 dan lingkaran 2 lalu ubah Color menjadi Alpha 0\% pada panel properties.

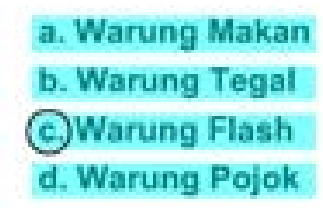

2. Dibawah ini yang tidak

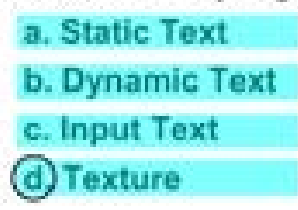


23. Seleksi seluruh objek di stage dan tekan F8. Pada kotak dialog yang muncul masukkan soal sebagai name, movie clip sebagi type dan ubah titik registrationnya di sebelah kiri atas lalu tekan ok.

24. Hapus movie clip soal dari stage lalu tekan Ctrl+L. Klik kanan movie clip soal pada panel Library yang muncul dan pilih Linkage. Pada kotak dialog yang muncul berikan tanda contreng/ centang pada Export for ActionScript lalu tekan ok.

25. Jika sudah tekan Ctrl+F7. Pada panel Component yang muncul tekan tanda + pada User Interface lalu drag ScrollPane ke stage. Ubah ukuran scrollpane sesuai keinginan anda dengan menggunakan Free Transform Tool

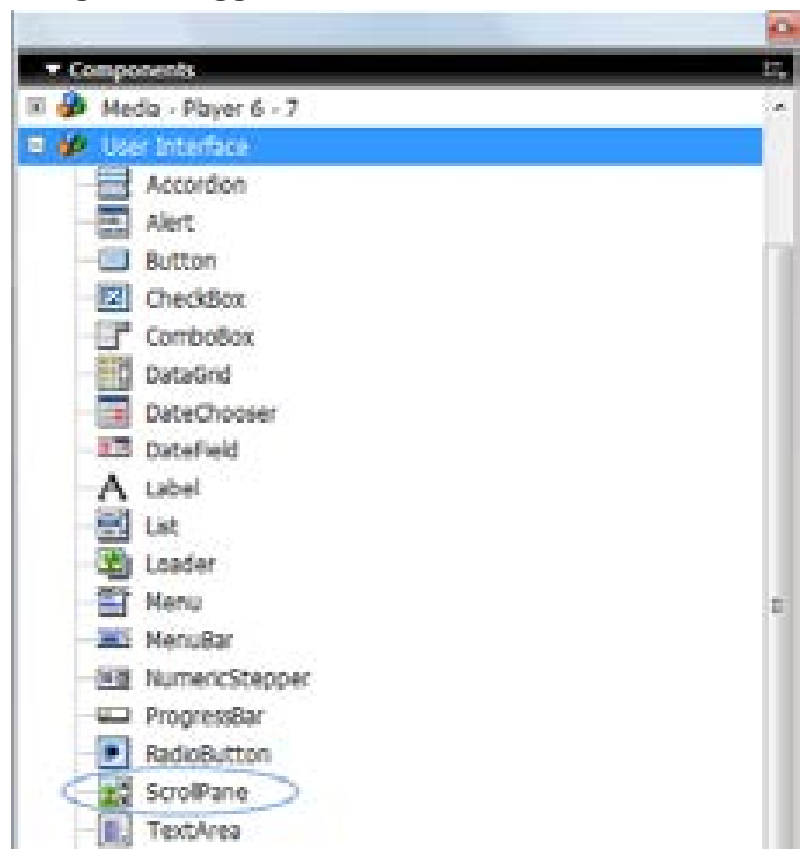

26. Seleksi scrollpane di stage dan masukkan sp di dalam kotak instance name pada panel properties. Pastikan anda masih 
menyeleksi scrollpane di stage lalu klik tab parameters di panel properties. Masukkan soal sebagai contentPath.

27. Buatlah Static Text bertuliskan Koreksi. Gambarlah persegi panjang dan tempatkan di tengah-tengah Static Text Koreksi.Seleksi Static Text koreksi dan persegi panjang tadi lalu tekan F8.Berikan koreksi_btn sebagai Name dan pilih Button sebagai Typenya lalu tekan ok. Seleksi koreksi_btn di stage lalu tekan F9 dan berikan script berikut :

//ketika tekanan mouse dilepaskan setelah ditekan

2 on (release)

3 //jika variable cek bernilai false

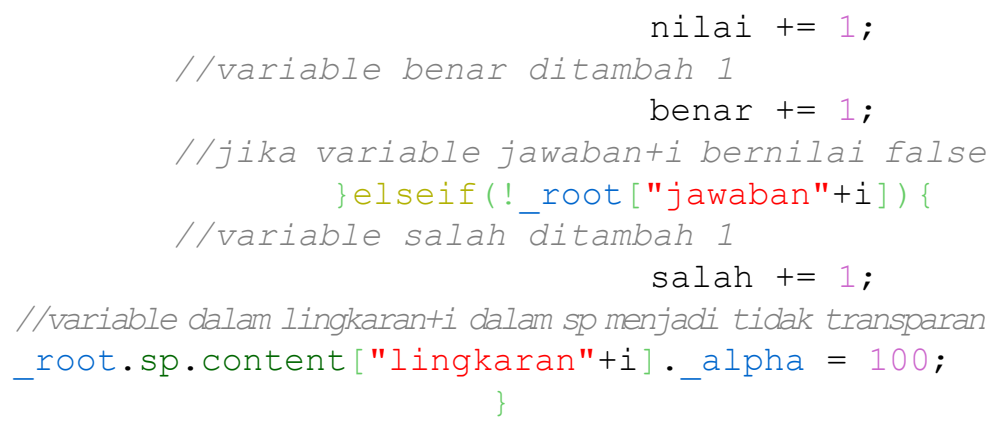

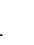

24
25
26


28. Buatlah Static Text bertuliskan Reset. Gambarlah persegi panjang dan tempatkan di tengah-tengah Static Text Reset. Seleksi Static Text Reset dan persegi panjang tadi lalu tekan F8.Berikan reset_btn sebagai Name dan pilih Button sebagai Typenya lalu tekan ok. Seleksi reset_btn di stagelalu tekan F9 dan berikan script berikut :

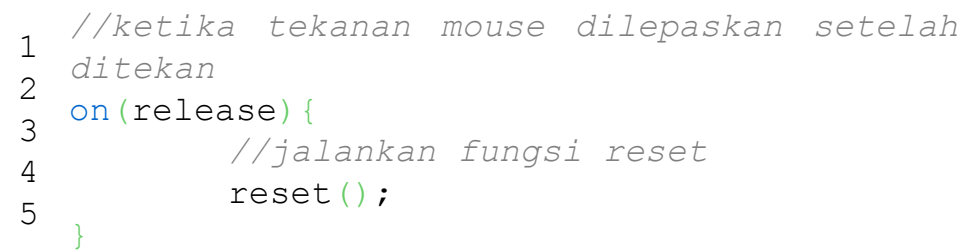

29. Buatlah 3 buah Static Text dan beri masing-masing tulisan berikut Benar: , Salah: , Nilai:

30. Buatlah 3 buah Dynamic Text dengan masing-masing Var benar, salah, nilai. Lalu tempatkan koreksi_btn, reset_btn, 3 buah Static Text dan Dynamic Text tadi seperti gambar di bawah ini :
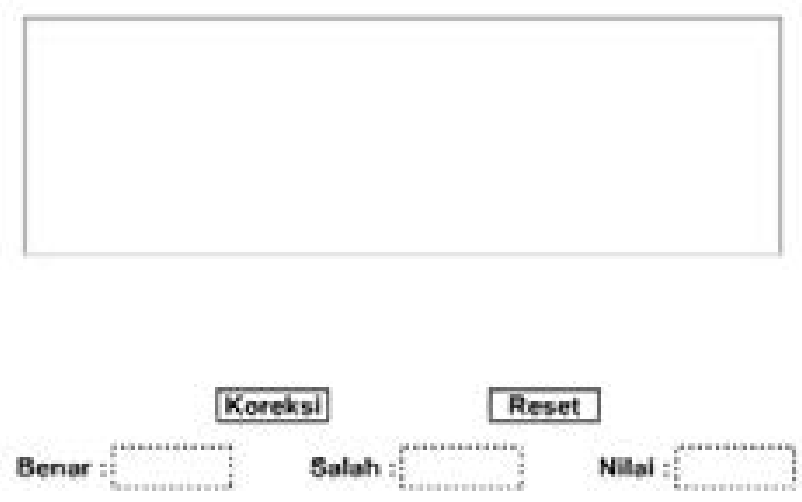

31. Klik frame 1 pada Timeline Scene 1 dan tekan F9. Pada kotak Action masukan script berikut : 


\section{MEMBANGUN MULTIMEDIA INTERAKTIF}

1 function reset ()

$2 / /$ membuat variable $i=1, i=2$

3 for $(i=1 ; i<3 ; i++)\{$

4 //posisi x movie clip silangti dalam sp $=-100$

5 root.sp.content ["silang"+i]. alpha $=0$;

6 //jawabanti dalam sp bernilai dengan false

$7 \quad$ root.sp.content ["jawaban"+i] = false;

8 //warna lingkaranti transparan

9 root.sp.content ["lingkaran"+i] . alpha = ;

10

11

cek = false;

12

tulis = true;

13

nilai $=0$;

14

benar $=0$;

salah $=0$;

15

16

17 //fungsi reset dijalankan sekali ketika frame ini dimainkan

18 reset();

32. Tekan Ctrl+Enter untuk melihat hasilnya : 


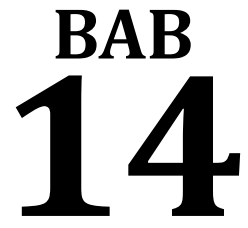

MEMASUKAN VIDEO

KEDALAM

FLASH 8

Dalam bab ini diuraikan mengenai:

[1]Memasukan Video kedalam Macromedia Flash Professional 8

Berikut ini akan dijelaskan langkah-langkah memasukkan video format FLV kedalam Macromedia Flash sehingga dapat kitapublish menjadi file flash biasa dengan format .swf Setelah file flash tersebut tercipta maka file flash tersebut dapat kita masukkan kedalam Microsoft FrontPage atau Microsoft PowerPoint (dalam pengerjaan Tugas Akhir di sekolah).

1. Buka Macromedia Flash (penulis menggunakan Macromedia Flash 8), pilih File, New, Flash Document untuk membuat dokumen flash yang baru.

2. Setelah itu pilih File, Import, Import Video untuk memasukkan video kedalam flash 


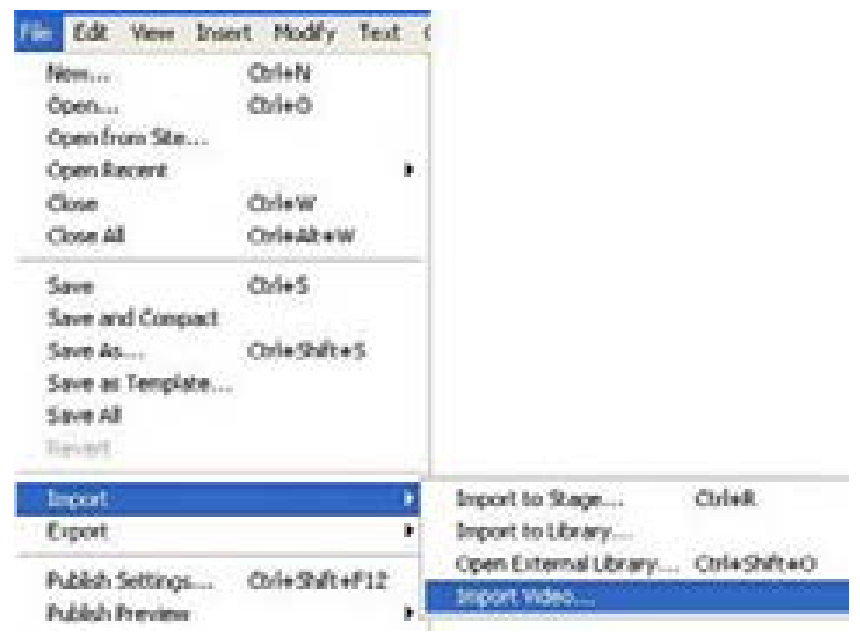

3. Akan tampil tampilan Select Video pilih pilihan pertama yaituOn your computer lalu untuk memasukkan video kita tinggal tekan tombol Browse dan pilih file video yang diinginkan

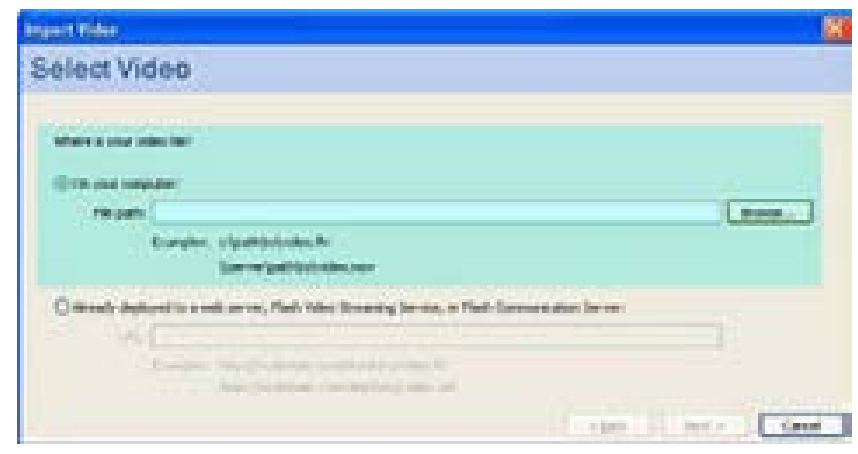

4. Setelah kita memilih video yang diinginkan, tekan tombol Next.

5. Akan tampil tampilan Deployment untuk memilih jenis-jenis deployment yang diinginkan, pada tampilan ini pilih saja jenis deployment yang kedua. 


\section{Import Video}

\section{Deployment}

How mould you the to deploy your video?

Oprogescive dourdaad from a web server

6) Stream froes flsch video stresming Service

Osteam from Flosh Communcotion Server

OEnbed video in SWF and ploy in timetine

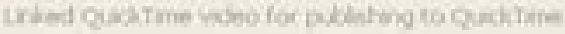

Setelah itu klik tombol Next.

6. Selanjutnya tampil tampilan untuk Skinning, pilih sembarangskin yang anda suka namun harap diperhatikan sebaiknya pilihskin dengan jenis over agar navigasi video dapat tetap terlihat pada saat file flash tersebut telah dipublish.

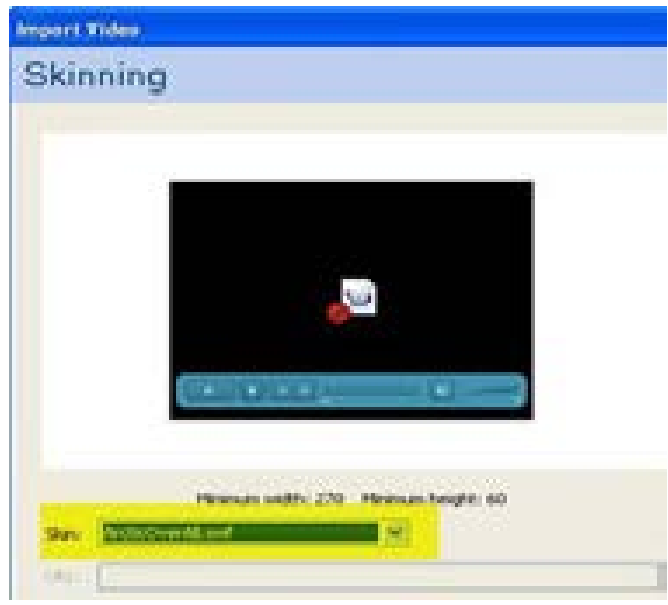

Setelah itu tekan tombol next kemudian tekan tombol finish.

7. Anda akan diminta untuk menyimpan file flash tersebut, simpan dengan nama sembarang (misalnya Video1.fla) kemudian tekan $O K$. 
Harus anda ingat file video (.flv) dan file project flash kita (.fla) HARUS TERLETAK PADA SATU FOLDER YANG SAMA ATAU FLASH KITA TIDAK AKAN DAPAT MENJALANKAN VIDEO TERSEBUT

Seperti anda lihat pada gambar dibawah ini tampilan video kita telah masuk kedalam lembar kerja (stage) dari flash, namun ukuran video kita belumlah sama dengan ukuran stage yang terdapat pada flash. Masih terdapat beberapa space kosong yang berwarna putih didalam stage.

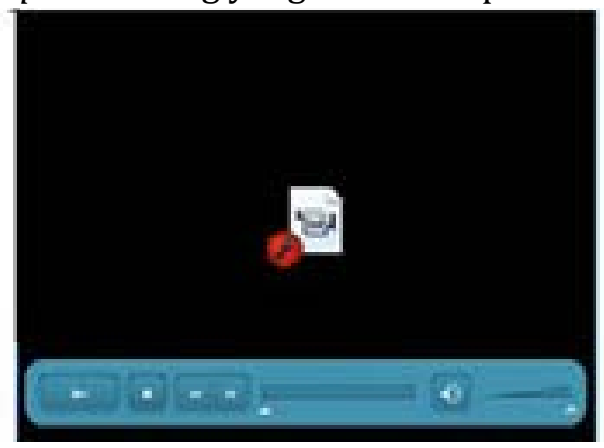

Untuk mengetahui ukuran besarnya video maka caranya adalah klik sekali pada object video, lalu lihat pada bagian properti yang terletak di sebelah bawah, akan terdapat ukuran panjang (width) dan lebar(height) dari video (biasanya 320 x 240). Untuk lebih jelasnya perhatikan gambar dibawah ini!

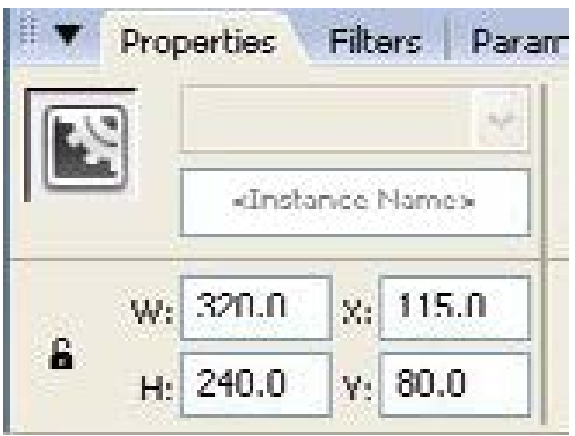


Langkah selanjutnya untuk menyamakan besarnya stage dengan besarnya video caranya adalah dengan klik kanan pada area lembar kerja (stage) yang masih kosong atau dengan memilih menu Modify, Document atau dengan shortcut key ctrl + j.Maka selanjutnya akan keluar tampilan seperti gambar dibawah ini.

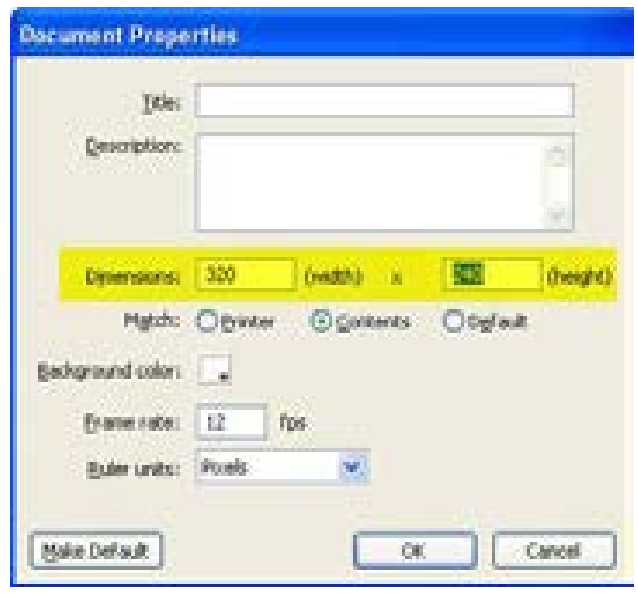

Pada bagian Dimensions ubah width dan heightnya sesuai dengan ukuran video yang ada (misalnya 320 dan 240). Setelah itu ubah Background color menjadi berwarna hitam. Tekan OK.

Selanjutnya geser video sedemikian agar tampilannya menjadi pas dan sesuai dengan lembar kerja (stage).

8. Setelah video dimasukkan kedalam lembar kerja kita, maka langkah berikutnya kita harus mempublish file flash kita agar menjadi format swf. sehingga dapat kita jalankan atau dimasukkan kedalam Powerpoint atau Frontpage. Caranya adalah dengan memilih menu File, Publish Settings kemudian beri tanda check pada pilihan Flash (.swf) tekan tombol Publish, tunggu beberapa saat lalu klik OK untuk kembali ke dokumen utama. 


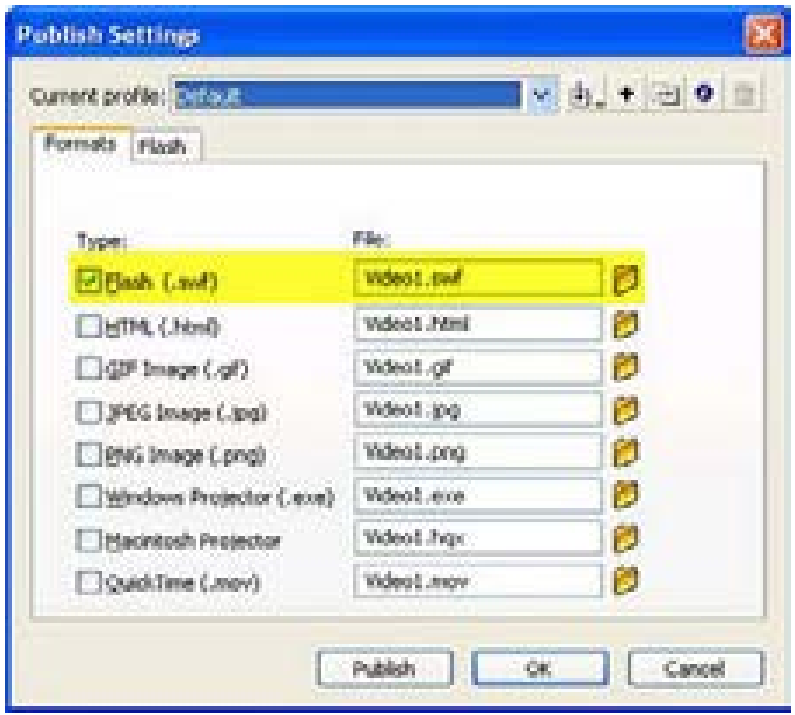

9. Simpan file anda, kemudian jalankan file flash anda yang berformat swf melalui Windows Explorer.

Video anda yang berformat FLV pun sudah dapat dijalankan...!!!

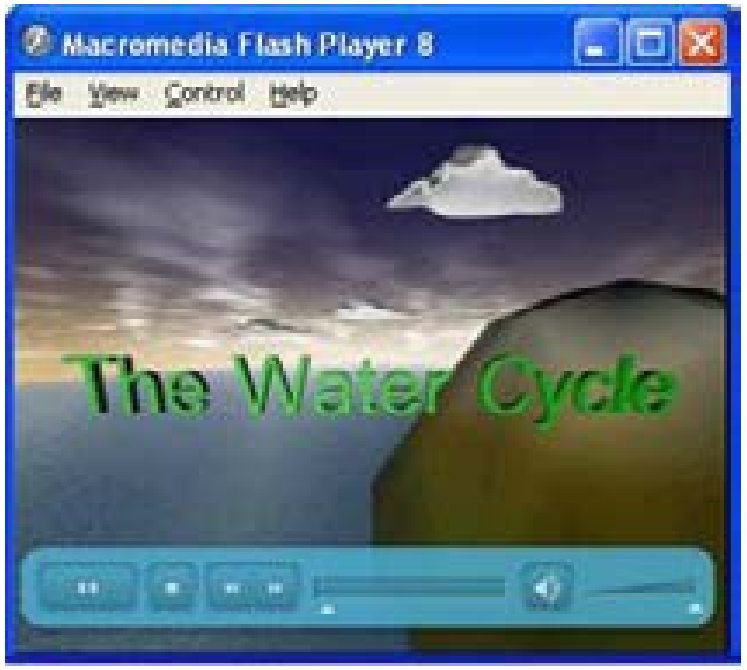




\section{DAFTAR PUSTAKA}

Adri, M. (2008). Strategi Pengembangan Multimedia Instructional Design. Jakarta: IlmuKomputer.com

Agnew, W. P, Kellerman, S. A \& Meyer, J. (1997). Multimedia in the

Classroom. New York: Van Nostrand Reinhold Company, Inc. Arif S. Sadiman dkk., Media Pendidikan. Jakarta: PT Raja Grafindo Persada, 1986

Arsyad, A. (2009). Media Pembelajaran. Jakarta: PT Raja Grafido Persada.

Bell, F. H. (1981). Teaching and Learning Mathematics (in secondary schools). Dubuque, Iowa: Wm. C. Brown Company Publishers.

Borg, W.R. dan Gall, M.D. (1983). Educational reseacher: an introduction ( $\left.4^{\text {th }} e d\right)$. New York: Longman.

Costu, S, Ayd. S, Filiz, M. (2009). Students' conceptions about browser-game-based learning in mathematics education: TTNetvitamin case. Procedia Social and Behavioral Sciences 1, 1848-1852

Cretchley, P \& Galbraith, P. (2003). Mathematics, computers, and umbilical cords. New Zealand Journal of Mathematics, volume yy 2003,xx xx.

Daryanto. (2011). Media pembelajaran. Bandung: Satu Nusa Departemen Pendidikan Nasional. (2003). Pendekatan Kontekstual. Jakarta: DEPDIKNAS

Eryslmaz, S. \& Aksan, E. (2011). Why don't mathematics teachers use instructional technology and materials in their courses? Procedia Social and Behavioral Sciences 15, 2471-2475 


\section{MEMBANGUN MULTIMEDIA INTERAKTIF}

Geisert, P. G \& Futrell, M. K. (1995). Teachers, computer, and curriculum. Boston: Allyn and Bacon.

Heinich, R. et al. (1996). Instructional media and technology for learning. Englewood Cliffts ( $4^{\text {th }}$ ed). Ne Jersey, Columbus, Ohio: Prentice-Hall, inc., A Simon \& Schuster company.

Jain, S. \& Dowson, M. (2009). Mathematics Anxiety as an Function of Multidimensional Self Regulation and Self-Efficacy. Contemporary Educational Psycholgy. Di ambil pada tanggal 13 Oktober 2013, dari http:Elsevier.com/locate/cedopsych. James \& James. (1976). Mathematic dictionary ( $4^{\text {th }}$ ed). New York: Van Nonstrand Reinhold.

Kemp, J. E. \& Dayton, D.K. (1985). Planning and producting instructional media ( $4^{\text {th }} e d$ ). New York: Harper and Row, Publisher inc.

Khambari,M. N, Luan, W. S, Ayub. A, F. (2010). Technology in Mathematics Teaching: The Pros and Cons. Procedia Social and Behavioral Sciences 8, 555-560

Khouyibaba, S. (2010). Teaching mathematics with technology.

Procedia Social and Behavioral Sciences 9, 638-643.

Knapp, L. R \& Glenn, A. D. (1996). Restructuring schools with technology. Boston: Allyn and Bacon

Kunandar. (2007). Guru professional implementasi ktsp dan sukses dalam sertifikasi guru. Jakarta: PT RajaGrafindo Persada.

Munadi, Y. (2008). Media pembelajaran, sebuah pendekatan baru. Jakarta: Gaung Persada Press.

Munir. (2013). Multimedia: konsep dan aplikasi dalam pendidikan. Bandung: Alfabeta.

NCTM. (1973). Instructional aids in mathematics. Washington: NCTM Neuman, W. L. (1997). Social research metho. ds qualitative and quantitative approaches. Third ed. Boston: Allyn and Bacon 
Öksüz, C, Uça, S. Designing multimedia videocases to improve mathematics teaching with technology: "technology integration into mathematics education" project. Procedia Social and Behavioral Sciences 1 (2009) 489-494

Pramono, G. (2010). Pemanfaatan multimedia pembelajaran. Jakarta: Pusat Teknologi Informasi dan Komunikasi Pendidikan Kementerian Pendidikan Nasional.

Renati Winong Wirosari, dkk. Adobe Flash CS3 untuk Pemula. Yogyakarta: ANDI, 2008

Roblyer, D. M. (2003). Integrating educational technology into teaching. Boston: Merrill Prenticce Hall

Rohayati,A. (2013). Pendekatan kontekstual dalam pembelajaran matematika untuk meningkatkan berpikir kritis.

Ronald H. Anderson. Pemilihan dan Pengembangan Media untuk Pembelajaran. Jakarta: Rajawali Pers, 1987

Ruffins, P. (2007). A real fear. Diverse: Issues in Higher Education. Smaldino, E. S, Lowther, L. D \& Russell, D. J. (2011). Instructional technology and media for learning. (Terjemahan Arif Rahman). Boston: Allyn and Bacon. (Buku asli diterbitkan tahun 2007). Soedjadi. (2000). Kiat Pendidikan Matematika di Indonesia. Jakarta: Dirjen Dikti Depdiknas.

Suherman, E. (2001). Strategi Pembelajaran Matematika Kontemporer. Bandung: JICA-UPI.

Sunaryo Soenarto, Pembelajaran Berbasis Multimedia sebagai Upaya Meningkatkan Kompetensi Hasil Belajar dan Persepsi Mahasiswa (Penelitian, 2009).

Suryabrata, S. (1995). Psikologi Pendidikan. Jakarta: PT. Raja Grafindo Persada.

Tim Divisi Penelitian dan Pengembangan. 2006. Macromedia Flash Professional 8. Yogyakarta: C.V Andi Offset. 
Warsita, B. (2008). Teknologi Pembelajaran, Landasan dan Aplikasinya. Jakarta: PT Raja Grafido Persada.

William, K. B \& Sawyer, C. S.(2007). Using information technology. (Terjemahan Nur Wijayaning Rahayu \& Arie Prabawati). London: McGraw Hill. (Buku asli diterbitkan tahun 2007). Winarno, Patwary, Yasid, dkk. (2009). Teknik evaluasi multimedia pembelajaran panduan lengkap untuk para pendidik dan praktisi pendidikan. Yogyakarta: Genius Prima Media. www.istiyanto.com www.warungflash.com

Yin, T. S, Ahmada, A, Fang, L. Y, Yen, Y. H, How. K. W. (2010). Incorporating Multimedia as a Tool into Mathematics Education: A Case Study on Diploma Students in Multimedia University. Procedia Social and Behavioral Sciences 8, 594599.

Yudhi Munadi, Media Pembelajaran, Sebuah Pendekatan Baru. Jakarta: Gaung Persada Press 


\section{TENTANG PENULIS}

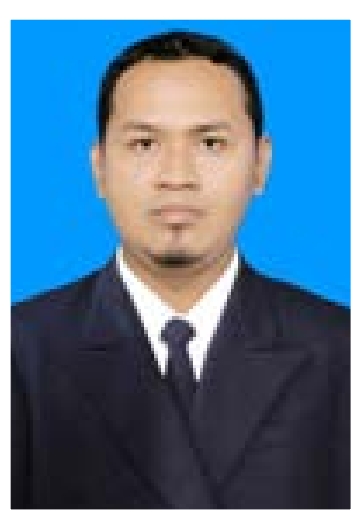

Syariful Fahmi, S. Pd.I., M. Pd. Lahir di Banjarnegara pada 14 Nopember 1983. Menyelesaikan pendidikan tinggi (S1) pada jurusan Pendidikan Matematika di Universitas Islam Negeri (UIN) Sunan Kalijaga tahun 2006, dengan judul skripsi: “Pembelajaran Materi Pengelolaan Data dengan Pendekatan Matematisasi Berjenjang pada Siswa Tunanetra Kelas D-6 SLB-A Yaketunis Yogyakarta". Kemudian melanjutkan pada jenjang Program Pascasarjana pada program studi yang sama di Universitas Negeri Yogyakarta (UNY), lulus pada 2014, dengan judul tesis: "Pengembangan Multimeda Interaktif Menggunakan Macromedia Flash 8 Professional dengan Pendekatan Kontekstual pada Pembelajaran Matematika Materi Bangun Ruang dan Keefektifannya terhadap Sikap Siswa pada Matematika dan ICT."

Saat ini penulis menjadi dosen tetap Fakultas MIPA Universitas Ahmad Dahlan (UAD) dengan mengampu beberapa mata kuliah, di antaranya adalah: Pengantar Ilmu Komputer, Pemrograman Komputer, Multimedia Pembelajaran, Desain Web, dan Multimedia Pembelajaran Matematika.

Dalam lima tahun terakhir ini, penulis aktif melakukan penelitian, di antaranya penelitian tentang: (1) Penerapan Teknologi WEB3D untuk Mengembangkan Medium Instruksional Materi Tata Surya Berbasis Komputer (2012); (2) Pengembangan Media Pembelajaran Interaktif Menggunakan 


\section{MEMBANGUN MULTIMEDIA INTERAKTIF}

Kvisoft flipbook Makeruntuk Matakuliah Multimedia Pembelajaran Matematika (2012); dan, (3) Penggunaan Lembar Kegiatan Mahasiswa Untuk Meningkatkan Prestasi Belajar Mahasiswa PGMIPA-U Pendidikan Matematika Pada Mata Kuliah Desain dan Analisis Eksperimen.

Penulis juga aktif dalam kegiatan pengabdian kepada masyarakat yang terkait dengan disiplinnya. Di antaranya adalah: (1) Pelatihan SPSS (2011); (2) Tim Pembuat Soal dan Juri Pada Olimpiade MIPA ISMUBARIS (2012); (3) Pelatihan Komputer Multimedia untuk Para Guru PAUD "Bina Buah Hati" (2012); (4) Tim Pembinaan/Motivator Olimpiade MIPA ISMUBARIS (Matematika dan Ilmu Pengetahuan Alam, Islam, Kemuhammadiyahan, Bahasa Arab, Bahasa Inggris) (2013); (5) Tim Pembuat Soal dan Juri Pada Olimpiade MIPA ISMUBARIS (2013); (6) Juri Olimpiade Sains Terapan (OST) Matematika Teknologi, Lomba OST SMK se-DIY tahun 2014 (2014); (7) Seminar Entrepreneurship Bagi Mahasiswa Jurusan Pendidikan Matematika Fakultas Sains dan Teknologi UIN Sunan Kalijaga Yogyakarta (2014).

Selain aktif mengajar dan meneliti, penulis juga produktif menulis dan mempublikasikan karya-karya ilmiahnya. Di antara karya penulis yang telah dipublikasikan adalah: (1) "Upaya Meningkatkan Minat Belajar Matematika Siswa dengan Menggunakan pendekatan Matematika realistik di Kelas IV Semester I SD N II Godean Sleman" (Jurnal MIPA EDUKATIKA, FKIP UAD, Vol. 5, No. 1, Nopember 2010); (2) “Pengembangan Media Pembelajaran Berbasis Multimedia Interaktif Menggunakan Kvisoft Flipbook Maker dalam Pembelajaran Matematika di SMA/MA Pada Kompetensi Dasar Menentukan persamaan Garis Singgung pada Lingkaran dalam Berbagai Situasi" (Jurnal MIPA EDUKATIKA, 
FKIP UAD, Vol. 5, No. 2, Mei 2011); (3) "Pengembangan Media Pembelajaran Interaktif Menggunakan Kvisoft Flipbook Maker untuk Pembelajaran Matematika SMA Standar Komptensi Persamaan Lingkaran dan Garis Singgungnya" (Jurnal Ilmiah AdMathEdu, Pendidikan Matematika Universitas Ahmad Dahlan, Vol. 3, No. 2 Desember 2013); (4) "Pengembangan Multimeda Macromedia Flash dengan Pendekatan Kontekstual dan Keefektifannya terhadap Sikap Siswa Pada Matematika" (Jurnal Agri Sains Lembaga Penelitian dan Pengabdian Kepada Masyarakat (LPPM) Universitas Mercubuana Yogyakarta, Vol. 5 No. 2 September 2014).

Sementara karya tulis/artikel yang disampaikan dalam forum-forum seminar ilmiah adalah menjadi pemakalah pada: (1) Prosiding Seminar Nasional Matematika dan Pendidikan Matematika FMIPA UNY 2011 (FMIPA UNY 2011, ISBN: 978979-16353-6-3) dengan judul artikel: "Pengembangan Media Pembelajaran Berbasis Multimedia Interaktif Menggunakan Kvisoft flipbook Makerdalam Pembelajaran Matematika Standar Komptensi Memecahkan Permasalahan yang Berkaitan Dengan Sistem Persamaan Linier dan Pertidaksamaan Linier Satu Variabel pada Siswa Kelas X." (2) Prosiding Seminar Nasional Matematika UDAYANA 2014 (Jurusan Matematika Fakultas MIPA Universitas Udayana 2014, ISSN:2406-9868) dengan judul artikel: "Pengembangan Multimeda Macromedia Flash dengan Pendekatan Kontekstual dan Keefektifannya terhadap Kecemasan Sikap Siswa Pada Matematika dan ICT."

Penulis bisa dihubungi di: 0813.2873.5393, atau kontak email: <syarifulfahmi@gmail.com> 



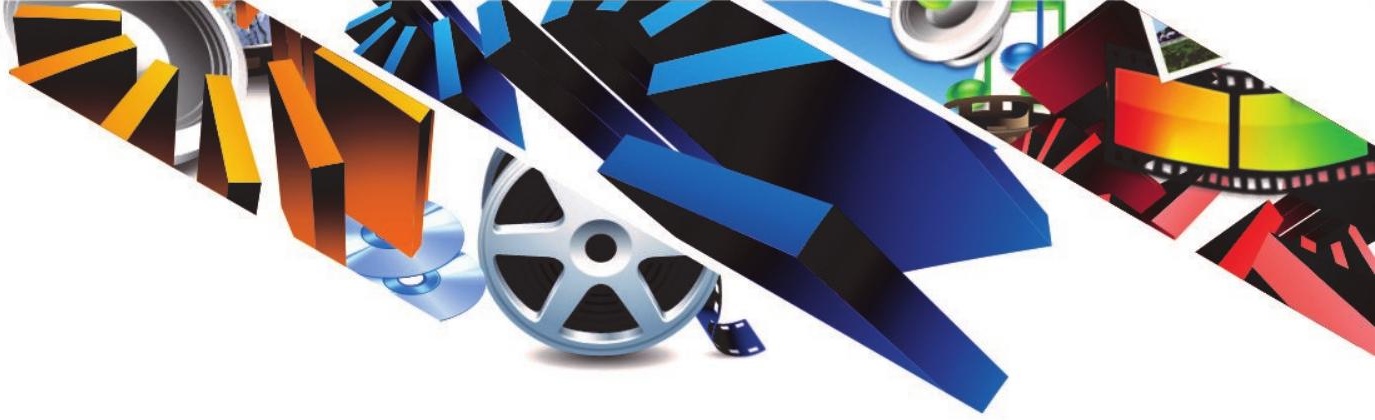

BUKU MULTIMEDIA PEMBELAJARAN ini tidak sekadar membahas teori tentang media, akan tetapi lebih menitikberatkan pada proses penalaran dan penyusunan multimedia yang menarik, informatif serta interaktif. Artinya, dengan belajar Multimedia Pembelajaran, mahasiswa dapat berpikir kritis serta sistematis, bukan hanya berteori tentang media, melainkan juga mengembangkannya. Oleh karena itu, penulis menyusun buku ajar ini disertai dengan cara-cara dan langkah-langkah membangun multimedia yang interaktif. Sebuah buku yang menarik dan mudah dipahami dan dipraktikkan.

Perum Graha Banguntapan B-23 Jl. Raya Pleret KM 2

Banguntapan Bantul Yogyakarta, 55791 Telepon: 081227475754

BILDUNG E-mail: bildungpustakautama@gmail.com Pustaka Utama www.penerbitbildung.com 